\title{
The Conjurer's Circle-The Fifth Amendment Privilege in Civil Cases
}

\author{
Robert Heidt $†$
}

\section{TABLE OF CONTENTS}

I. The Versatility of the Privilege as a Weapon ....... 1065

A. Occasions for Use .................... 1065

B. Resistant to Attack ................... 1071

1. Attacking on the Ground that the Response Will Not Incriminate ................. 1071

2. Attacking on the Ground that Prosecution is Barred by Double Jeopardy ............ 1075

3. Attacking on the Ground that Prosecution is Barred by the Statute of Limitations ........ 1078

4. Attacking on the Ground that Prosecution is Barred by Past Grants of Use Immunity ..... 1080

C. Advantages Secured ................. 1081

II. The Modest Need for the Privilege in Civil Cases..... 1082

III. Remedies......................... 1087

A. Remedies to reject $\ldots \ldots \ldots \ldots \ldots \ldots \ldots \ldots \ldots, 1088$

1. Tinkering with Hoffman ............ 1088

a. Compelling a Response When Prosecution is Unlikely ................... 1089

b. Altering the Standards for Finding Incriminating Potential ............... 1092

2. Protective Orders .................. 1095

3. Judicial Grants of Use Immunity .......... 1100 
Fifth Amendment

4. The Prospective Taint Fantasy ........... 1102

B. Remedies to Allow .................. 1107

1. Informing the Fact Finder............ 1108

a. The Constitutional Objections .......... 1109

b. The Evidentiary Objections .......... 1114

i. The Need for an Evidentiary Status 1114

ii. Invokings as Statements of a Party 1116

iii. Employee Invokings as Vicarious Statements of a Party .......... 1119

2. Shifting the Burdens $\ldots \ldots \ldots \ldots \ldots \ldots \ldots, 1126$

3. Barring the Midnight Witness .......... 1130

4. Controlling the Remedies When Prosecution is Pending 
By incantations a conjurer draws a circle around a person concealing all within from demons.

Book of Magic

He could not draw a conjurer's circle around the whole matter lby relying on the privilege]....

United States v. Sullivan, 274 U.S. 259, 266 (1927) (Holmes, J.)

Holmes' dictum did not stand: the privilege against self-incrimination allows the wholesale concealment of evidence through incantation. Properly versed in the lore, civil defendants and their employees who intone the formula at every opportunity can draw a surprisingly wide conjurer's circle around their conduct, a circle of mystery that works to their advantage. In civil litigation between private parties, current Fifth Amendment jurisprudence sacrifices the determination of truth, the policies underlying liberal discovery, and the vindication of public and private rights to an extent rarely appreciated.

The invocation of the Fifth Amendment privilege in a civil case between private parties calls into play considerations different from those pertinent in a criminal case. ${ }^{1}$ The difference has been recognized, and the underlying policies discussed. ${ }^{2}$ But no one has systematically explored the operation of the privilege in the frequently complex procedural battleground of civil litigation.

This Article highlights the marked utility of the privilege to defendants in civil cases. It demonstrates that private plaintiffs ${ }^{3}$ will rarely be able to

1. The privilege against self-incrimination has rightly been revered as a shield for defendants in criminal cases. See, e.g., Griswold, The Fifth Amendment: An Old and Good Friend, 40 A.B.A. J. 502 (1954); McNaughton, The Privilege Against Self-Incrimination, 51 J. CRIM. L., CRIMINOLOGY, \& POLICE SCI. 138 (1960). Nothing here is intended to suggest any need for changing the operation of the privilege in criminal proceedings.

2. The literature on the use of the Fifth Amendment privilege in civil cases is extensive. Sce, e.g., Kaminsky, Preventing Unfair Use of the Privilege Against Self-Incrimination in Private Civil Litigation: A Critical Analysis, 39 BROOKLYN L. REV. 121 (1972); Note, Use of the Privilege Against SelfIncrimination in Civil Litigation, 52 VA. L. REV. 322 (1966). Representative commentaries advocate allowing plaintiffs to maintain actions despite their assertion of the privilege, see Comment, Plaintiff as Deponent: Invoking the Fifth Amendment, 48 U. CHI. L. REV. 158 (1981), and compelling testimony despite the privilege by the granting of protective orders, see Donnici, The Privilege Against Self-Incrimination in Civil Pre-Trial Discovery: The Use of Protective Orders to Avoid Constitutional Issues, 3 U.S.F.L. REV. 12 (1968), and immunity, see Note, Constitutional Law: Self-Incrimination and Court Granted Immunity in Civil Litigation, 27 OKLA. L. REV. 243 (1974).

3. This Article focuses on civil litigation in which the government is not a party. Because the government may compel responses by giving use immunity, see 18 U.S.C. $\$ 6002$ (1976), the privilege is a much less potent weapon when the government is the plaintiff or when the government's case is consolidated for discovery with private cases. See generally infra pp. 1100-02 (arguing that judicial grants of use immunity are an unsatisfactory solution to privilege problems in civil suits between private parties). 
pierce the conjurer's circle and compel responses-at least when defense counsel exploit the privilege's full potential. Yet the policies behind the privilege do not apply with full force in civil cases and do not preclude allowing plaintiffs some remedies to reduce the disadvantages they suffer when the privilege is used against them. The Article evaluates possible remedies for such plaintiffs and identifies certain remedies that should be routinely allowed.

\section{The Versatility of the Privilege as a Weapon}

The privilege provides defense counsel determined to resist discovery and retard the progress of the civil action with a potent weapon against private plaintiffs. Its potency derives from the many occasions on which it may be invoked and from its resistance to attack when invoked.

\section{A. Occasions for Use}

The privilege may be used in a great range of civil cases. It may be used whenever information sufficiently relevant to civil liability to be discoverable provides even a clue that might point a hypothetical government investigator toward evidence of criminal conduct. ${ }^{4}$ In a routine divorce case, for example, a defendant husband may invoke by arguing that his response to questions about his assets would provide clues suggesting that the assets had been acquired illegally or had not been fully reported on his tax returns. ${ }^{5}$ More obviously, the privilege may be used in civil actions where conduct giving rise to civil liability also constitutes an element of a crime. Examples include divorce actions involving adultery, ${ }^{6}$ civil rights actions involving assaults, ${ }^{7}$ securities actions involving fraud ${ }^{8}$ personal injury actions involving criminal negligence, ${ }^{9}$ and antitrust actions involving violations of the Sherman Act. ${ }^{10}$

4. See infra p. 1072.

5. Cf. Depew v. Hanover Ins. Co., 73 F.R.D. 101 (E.D. Tenn. 1976) (in civil case between private parties no adverse inference may be drawn from invoking of privilege by plaintiff in response to questions about tax returns).

6. See Annest y. Annest, 49 Wash. 2d 62, 298 P.2d 483 (1956).

7. See Coalition of Black Leadership v. Cianci, 480 F. Supp. 1340, 1343-44 (D.R.I. 1979).

8. See In re Penn Cent. Sec. Litig., 347 F. Supp. 1347 (E.D. Pa. 1972); cf. Amana Soc'y v. Selzer, 250 Iowa 380, 94 N.W.2d 337 (1959) (action against fiduciary involving fraud); Ikeda v. Curtis, 43 Wash. 2d 449, 457-58, 261 P.2d 684, 689-90 (1953) (action, against seller of real estate and hotel business, involving fraud and prostitution).

9. See Walton v. Robert E. Haas Constr. Corp., 259 So. 2d 731, 733-34 (Fla. Dist. Ct. App. 1972) (automobile accident).

10. See In re Folding Carton Antitrust Litig. (Appeal of Brown), 609 F.2d 867 (7th Cir. 1979). For the use of the privilege in other non-criminal proceedings, see Baxter v. Palmigiano, 425 U.S. 308, 316-320 (1976) (prison disciplinary action); Gabrilowitz v. Newman, 582 F.2d 100, 103-06 (1st Cir. 1978) (school disciplinary action); Ryan v. Montana, 580 F.2d 988 (9th Cir. 1978) (probation revocation action); Arthurs v. Stern, 560 F.2d 477 (1st Cir. 1977) (physician disciplinary action); In 
The privilege may be used even if the invokers realize, as a practical matter, that they would not be prosecuted for the conduct they would otherwise be forced to reveal. ${ }^{11}$ For instance, the policies of antitrust prosecutors eliminate any likelihood that a corporate executive will be prosecuted for assisting his company in a joint research project, even if the project constitutes an antitrust violation when evaluated under the rule of reason. ${ }^{12}$ Yet because any violation of either section of the Sherman Antitrust Act is technically a crime, ${ }^{13}$ the executive will be able to invoke the privilege in response to any inquiries about the project when the company is sued in a private action. As a result, he may conceal much information from the private plaintiff, an advantage available, ironically, only because Congress so opposed antitrust violations that it created criminal as well as

re Meredosia Harbor \& Fleeting Serv., 545 F.2d 583, 590-91 (7th Cir. 1976) (bankruptcy); Iannelli v. Long, 487 F.2d 317 (3d Cir. 1973) (civil tax action); Stillman Pond, Inc. v. Watson, 115 Cal. App. 2d 440, 444, 252 P.2d 717, 718 (1953) (license revocation action against real estate agent).

11. The long-standing American rule is that the privilege may be invoked as long as a mere "possibility" of prosecution for the crimes suggested by the response exists. See United States v. Johnson, 488 F.2d 1206, 1209 (1st Cir. 1972); United States v. Miranti, 253 F.2d 135, 139 (2d Cir. 1958). This rule differs from the English rule requiring "that the danger [of prosecution] to the apprehended must be real and appreciable, with reference to the ordinary operation of law in the ordinary course of things." The Queen v. Boyes, 1 Best \& Smith 311, 331, 121 Eng. Rep. 730, 738 (Q.B. 1861). At one time American law appeared to adopt the English view. See Heike v. United States, 227 U.S. 131 (1913).

In the modern era a lower American court, indignant at the obstructive potential of the privilege in civil cases, has occasionally adopted the English view, only to be promptly reversed. E.g., In re Brogna, 589 F.2d 24 (1st Cir. 1978) (reversing district court order compelling testimony); In re Folding Carton Antitrust Litig., 465 F. Supp. 618 (N.D. Ill. 1979), rev'd, 609 F.2d 867 (7th Cir. 1979).

Only a statutory grant of use immunity by the prosecution is sufficient to negate the possibility of future prosecution and, hence, to allow compulsion of testimony. See United States v. D'Apice, 664 F.2d 75, 77-78 (5th Cir. 1981) (federal prosecutor has no authority to confer non-statutory use immunity on witness because immunity would not bind prosecutors in other districts); United States v. Smith, 436 F.2d 787, 790 (5th Cir.) (court has no authority to guarantee immunity from prosecution to alibi witnesses or to guarantee that their testimony could not be used against them in later prosecution), cert. denied, 402 U.S. 976 (1971); Ellis v. United States, 416 F.2d 791, 796 (D.D.C. 1969) (court has no authority to confer immunity in order to compel witness to testify). But see Little Rock School Dist. v. Borden, Inc., 1979-2 Trade Cas. (CCH) I 62, 809, at 78, 722-23 (E.D. Ark. 1979) (non-statutory guarantee of use immunity by federal prosecutors is constitutionally enforceable "solemn promise" allowing compulsion of testimony).

12. The Antitrust Division of the United States Department of Justice has long adhered to an announced policy of criminally prosecuting only those antitrust violations involving price-fixing and clearly predatory conduct. Speech by Assistant Attorney General Donald I. Baker to the Antitrust Law Briefing Conference (February 28, 1977) (on file with Yale Law Journal). Consequently, those who invoke the Fifth Amendment in civil cases because their responses would provide clues or evidence of monopolizing, or participation in tying arrangements, group boycatts, exclusive dealing arrangements, vertical territorial restraints, or any rule of reason violations face no realistic danger of prosecution at the federal level.

13. See 15 U.S.C. $\$ \S 1-2(1976)$. The Supreme Court, in United States v. United States Gypsum Co., 438 U.S. 422,443 (1978), suggested that intent to restrain trade must be proved in any criminal prosecution under the Sherman Act, even though such proof may not be necessary to establish civil liability under the Act. This holding suggests that not all civil antitrust violations will necessarily constitute crimes. Nevertheless, all responses tending to show a rule of reason violation of the Sherman Act may still incriminate for Fifth Amendment purposes since proof of intent remains a possibility. 
civil sanctions.

The prototypical use of the privilege by a civil defendant on the witness stand represents but one of the many stages in the civil case when the privilege may be used. When defendants are individuals or sole proprietorships, ${ }^{14}$ they may also use the privilege to refuse to submit answers to allegations in the complaint ${ }^{15}$ and to refuse to respond to interrogatories, ${ }^{16}$ requests for admissions, ${ }^{17}$ and questions at depositions. ${ }^{18}$ They may also be able to use the privilege to resist requests and subpoenas for documents to the same extent that they could use it to resist government subpoenas for documents in criminal cases. ${ }^{19}$

Because an organizational entity like a corporation or partnership has no Fifth Amendment privilege, ${ }^{20}$ it may not invoke the privilege itself. Nevertheless, a corporate defendant may use the privilege of its employees $^{21}$ to its advantage in a number of ways. Most importantly, its employees may invoke the privilege in order to resist any potentially incriminating questions at deposition or at trial..$^{22}$ In addition, any attempt by the

14. The privilege applies to the business records as well as to the personal documents of a sole proprietor. See Bellis v. United States, 417 U.S. 85, 87-88 (1974) (dictum).

15. See de Antonio v. Solomon, 42 F.R.D. 320, 322 (D. Mass. 1967).

16. See Gordon v. FDIC, 427 F.2d 578, 580 (D.C. Cir. 1970); United States v. Forty-Seven Bottles, More or Less, of Jenasol, 26 F.R.D. 4 (D.N.J. 1960); Paul Harrigan \& Sons, Inc. v. Enterprise Animal Oil Co., 14 F.R.D. 333 (E.D. Pa. 1953).

17. In a few instances courts have compelled answers to requests for admissions on the ground that under FED. R. CIV. P. 36(b) such admissions could not be used as evidence in other cases. E.g., Woods v. Robb, 171 F.2d 539 (5th Cir. 1948); United States v. LaFontaine, 12 F.R.D. 518 (D.R.I. 1952). Because that approach overlooks the possibility that the admissions may provide clues that can be used in future prosecutions, those cases are now regarded as "clearly untenable." Note, The Constitutional Limits of Discovery, 35 IND. L.J. 337, 346 (1960); see 8 C. WRIGHT \& A. MILLER, FEDERAL PRACTICE AND PROCEDURE $\S 2018$, at 142 (1970).

18. Sec, e.g., Duffy v. Currier, 291 F. Supp. 810 (D. Minn. 1968); National Discount Corp. v. Holzbaugh, 13 F.R.D. 236 (E.D. Mich. 1952).

19. See Boyd v. United States, 116 U.S. 616 (1886); Minnesota State Bar Ass'n v. Divorce Assistance Ass'n, 311 Minn. 276, 248 N.W.2d 733 (1976); Rice v. State Bd. of Medical Examiners, 208 Okla. 440, 257 P.2d 292 (1953). But see United States v. Roundtree, 420 F.2d 845, 852 (5th Gir. 1969).

The protection given documents in civil and criminal cases was restricted in Fisher v. United States, 425 U.S. 391 (1976). Fisher held that the production of an accountant's workpapers could be compelled from the accountant's client, despite their tendency to incriminate the client, because the workpapers were not of a testimonial character. Id. at 409-14. When the implied admissions from producing documents incriminate, however, the documents may still be suppressed. Id. at 410-414.

20. All business entities with their own legal identity for Fifth Amendment purposes-and therefore unable to invoke the privilege on their own behalf-will be referred to simply as "corporations." This group includes corporations, see George Campbell Painting Corp. v. Reid, 392 U.S. 286, 288-89 (1968); Oklahoma Press Publishing Co. v. Walling, 327 U.S. 186, 196, 208-10 (1946), partnerships, see Bellis v. United States, 417 U.S. 85 (1974), and unincorporated associations, see Local 57, Int'l Union of Operating Eng'rs v. Wertz, 326 F.2d 467 (1st Cir. 1964). It does not include sole proprietorships. Bellis, 417 U.S. at 88 .

21. For the sake of brevity, all officers, employees, and agents of a business entity whose actions can render the business entity liable will be referred to simply as "employees."

22. See Malloy v. Hogan, 378 U.S. 1, 12-14 (1964); cf. Emspak v. United States, 349 U.S. 190 (1955) (upholding claim of privilege by member of union in congressional investigation of union). 
plaintiff to depose the corporation itself (under the special rules of discovery created for this purpose) ${ }^{23}$ may be blocked because the agent the corporation appoints to testify on its behalf may invoke his own privilege whenever his testimony might incriminate him. ${ }^{24}$

Under certain circumstances a corporation may even use the privilege of its employees to refuse to submit an answer, or to refuse to respond to interrogatories and requests for admissions. One possible method is to ensure that no employee or agent may sign the corporation's response without incriminating himself. ${ }^{25}$ Although the corporation must attempt to find an agent to sign the response who will not invoke the privilege, ${ }^{26}$ the plaintiff may have no solution if such an agent cannot be found. ${ }^{27}$

Even if the plaintiff identifies an agent able to sign without fear of incrimination, the defendant corporation may raise another claim to resist these discovery requests. It may argue that the appointed agent is unable to respond because the employees with the requested information refuse to reveal the information to the agent on the ground that it would tend to incriminate them. If sustained, this "impossibility" claim would open a

23. FED. R. Giv. P. 30(b)(6), 31(a), 32(a)(2). Under these rules, the plaintiff may depose an agent of the defendant corporation who will testify on the corporation's behalf at the deposition. The deposition of the agent may be used against the defendant corporation for any purpose. FED. R. CIV. P. $32(\mathrm{a})(2)$.

24. Cf. Curcio v. United States, 354 U.S. 118 (1957) (custodian of union records could invoke privilege in response to questions of grand jury investigating union when answers would incriminate him).

25. See In re Siegel Trading Co. [1977-1980 Transfer Binder] CoMM. FUT. L. REP. (CCH) I] 20,637 , at 22,600-01 (1978) (declining to penalize corporate defendant for failure to respond to requests for admission because no agent could be found who could respond on behalf of defendant without incriminating himself); Priebe v. World Ventures, Inc., 407 F. Supp. 1244, 1246 (C.D. Cal. 1976) (ordering corporation to answer interrogatories but noting that a "reformulation" of the order might be necessary if corporation was unable to appoint anyone to answer who would not thereby incriminate himself); see also United States v. Kordel, 397 U.S. 1, 9 (1970) (declining to decide the "troublesome question" arising where no one could answer interrogatories addressed to a corporation without subjecting himself to danger of prosecution).

26. See United States v. 3963 Bottles, More or Less, of Enerjol Double Strength, 265 F.2d 332, 336 (7th Cir. 1959). The Federal Rules envision that the agent is to interrogate corporate employees so thoroughly that he will know all the information they possess that is pertinent to the interrogatot ries. See General Dynamics Corp. v. Selb Mfg. Co., 481 F.2d 1204, 1210 (8th Cir. 1973). Experienced litigators may feel, however, that this duty is honored more in the breach. Often the agent starts out uninformed about corporate matters and seems less than eager to undertake an extensive investigation.

27. How often such a case arises is unclear. In light of the great range of information that may "tend to incriminate," the corporation's response may indeed tend to incriminate all of its employees when the corporation is small. To be sure, corporate counsel may be able to respond to these discovery requests on behalf of the corporation and may be unwilling or unable to invoke the privilege. But corporate counsel may take the position that information in his possession is protected by the workproduct or attorney-client privileges. See Weissenberger, Toward Precision in the Application of the Attorney-Client Privilege for Corporations, 65 IOWA L. REV. 899, 903-04 n.26 (1980) (discussing suppression of corporate information through use of corporate attorney's privilege); Note, Privileged Communications-Inroads on the "Control Group" Test in the Corporate Area, 22 SYRACUSE L. REV. 759, 766 (1971) (same). 
major loophole for corporations seeking to resist discovery. ${ }^{28}$ Yet the corporation's argument-that the employees' refusal to cooperate with the agent puts his information beyond its reach and prevents it from replying-contains some surface appeal. ${ }^{29}$ The ingenuous rejoinder merely relies on the tautology that the employee's information is the corporation's information; when the corporation does not respond to the interrogatories with all its information, it violates the discovery rules regardless of the agent's good-faith efforts to comply. ${ }^{30}$

A cognate issue arises from the employees' claim that incriminating themselves to the corporate agent creates the same dangers as incriminating themselves to the plaintiff, and hence should not be compelled. ${ }^{31}$ But again, the tautology goes, when the employees are asked to assist the agent, they are being asked to act in a representative capacity-as corporation employees. Because they are assisting the agent in their capacity as representatives of a corporation that has no privilege, they have no privi-

28. This impossibility claim appears to be asserted most frequently in private antitrust cases. See Cooper, Fifth Amendment Rights in Private Treble Damage Litigation, 48 ANTITRUST L.J. 1381, 1392-95 (1979).

29. The language of some cases suggests without elaboration that a corporation need reply only with the information available from sources under its control. E.g., Holt v. Southern Ry. Co., 51 F.R.D. 296, 299 (E.D. Tenn. 1969). Arguably this would not include information suppressed from its agent by a personal privilege of its employees.

30. E.g., In re Anthracite Coal Antitrust Litig., 1979-1 Trade Cas. (CCH) I 62,511 (M.D. Pa. 1979) (defendant corporation violates discovery rules and subjects itself to Rule 37 sanctions even when compliance is prevented by employees' assertions of privilege); In re Folding Carton Antitrust Litig., 76 F.R.D. 417 (N.D. Ill. 1977) (same); see also George Campbell Painting Corp. v. Reid, 392 U.S. 286 (1968) (penalizing corporation for its officer's refusal to waive privilege).

Even though the defendant corporation that raised the "impossibility" claim may therefore be required to submit a different response to plaintiff's complaint, interrogatories, and requests for admissions, its initial response may have achieved the purpose of delaying plaintiff's discovery. Because the corporation can muster some colorable arguments for its "impossibility" claim, Rule 37 sanctions against it are unlikely.

31. The employee is plainly forced to put himself in danger of prosecution when he is forced to tell all to the agent, for the agent may reveal his statements in the corporation's response. The agent may even be required to indicate that the source for the information in the response was the employee. B\&S Drilling Co. v. Halliburton Oil Well Cementing Co., 24 F.R.D. 1, 14 (S.D. Tex. 1959). Consequently, being compelled to talk to the agent may be as likely to lead to criminal prosecution as being compelled to talk to the opposing party directly. The employee is then as much the instrument of his own undoing, and faces as cruel a choice between incrimination, perjury, and contempt, in the one case as in the other. Cf. $8 \mathrm{~J}$. WIGMORE, EVIDENCE $\$ 2259 \mathrm{~b}$, at 359 (J. McNaughton rev. ed. 1961) (corporate custodian's unsuccessful arguments against being forced to produce incriminating corporate documents echo successful arguments of individuals asked to produce their incriminating documents). Nevertheless, Wilson v. United States, 221 U.S. 361 (1911), would seem to foreclose the claim that employees are entitled to invoke the Fifth Amendment rather than assist the corporate agent:

A command to the corporation is in effect a command to those who are officially responsible for the conduct of its affairs. If they, apprised of the writ directed to the corporation, prevent compliance or fail to take appropriate action within their power for the performance of the corporate duty, they, no less than the corporation itself, are guilty of disobedience and may be punished for contempt.

Id. at 376. But see Paul Harrigan \& Sons, Inc. v. Enterprise Animal Oil Co., 14 F.R.D. 333 (E.D. $\mathrm{Pa}$. 1953) (suggesting that privilege protects individual employees from being forced to disclose incriminatory information to designated corporate agent). 
lege. This tautology, however, conflicts with the rule that an employee may invoke the privilege rather than sign the corporation's response to interrogatories, ${ }^{32}$ an act also performed in a representative capacity. Whatever the final decision on such defense claims, their mere assertion ought to suggest that the value of the privilege in retarding the plaintiff's discovery and increasing his expenses may only be limited by the cleverness of the defendants' attorneys.

By invoking the privilege at every opportunity, defendants and their employees may conceivably deflect all discovery requests except for document requests aimed at defendant corporations. Even if future cases reduce a corporation's ability to use the privilege of its employees to resist discovery requests directed to it, the employees will surely still be able to invoke the privilege at depositions. Yet assertions of privilege that nullify the value of depositions (the most fruitful discovery vehicle) most threaten the policies underlying liberal discovery. ${ }^{33}$

Because the discovery rules provide that privileged information is not discoverable, ${ }^{34}$ none of the usual sanctions for failure to grant discovery ${ }^{35}$ may be imposed when discovery is resisted by claiming the privilege. Even the discovery rules that seek to narrow the issues by requiring a defendant either to admit or to deny specific allegations-such as the rules governing answers and requests for admissions-may be frustrated by invoking the privilege. According to the weight of authority, invoking the privilege on the answer $^{36}$ or in response to requests for admissions ${ }^{37}$ gives the defen-

32. See United States v. Kordel, 397 U.S. 1, 7 (1970). When the Court embraced this rule in Kordel, it seemed to be under the misconception that the privilege would no longer be available once the prosecution of the employee was completed. Id. at 9 . In fact, however, the privilege remains available as long as the response may be used against the invoker in any possible future prosecution. See, e.g., In re Folding Carton Antitrust Litig. (appeal of Brown), 609 F.2d 867 (7th Cir. 1979).

33. The literature explaining the reasons supporting liberal discovery is extensive. E.g., Frost, The Ascertainment of Truth by Discovery, 28 F.R.D. 89 (1960); Holtzoff, The Elimination of Surprise in Federal Practice, 7 VAND. L. REV. 576 (1954).

34. FED. R. CIV. P. 26(b)(1); see also FED. R. CIV. P. 36(a) (providing for "objection" to requests for admission); 4A J. MOORE, J. LUCAS \& D. EPSTEIN, MOORE'S FEDERAL PRACTICE I 36.04[3] (2d ed. 1982) (discussing claim of privilege against self-incrimination in response to request for admission). FED. R. CIV. P. 30(c) provides that at depositions, evidence objected to shall be taken subject to the objections. The courts, however, have held that this provision does not require a response where the objection rests on the privilege against self-incrimination. E.g., Perrignon v. Bergen Brunswig Corp., 77 F.R.D. 455, 460-61 n.4 (N.D. Cal. 1978); Preyer v. United States Lines, Inc., 64 F.R.D. 430 (E.D. Pa. 1973), affd, 546 F.2d 418 (3d Cir. 1976).

35. See FED. R. CIV. P. 37 (authorizing sanctions, including contempt and dismissal, for failure to comply with discovery orders).

36. See de Antonio v. Solomon, 42 F.R.D. 320, 322 (D. Mass. 1967); 5 C. WRIGHT \& A. MILleR, FEDERAL PRACTICE AND PROCEDURE § 1280, at 360-61 (1969). But see In re Sterling Harris Ford, Inc., 315 F.2d 277 (7th Cir.) (respondents to a turnover petition are not entitled to use privilege "as a sword permitting them to circumvent Rule 8(d) F.R. Civ. P. . . ."), cert. denied, 375 U.S. 814 (1963).

37. See 4A J. MOORE \& J. LUCAS, supra note 34, II 36.04[3]; 8 C. WRIGHT \& A. MILLER, supra note $17, \S 2018$, at 145.48 . 
dant the benefits of a verified good faith denial, in that the plaintiff is put to his proof. To take the allegations as admitted, according to one court, would impose an impermissible cost on invoking the privilege. ${ }^{38}$

\section{B. Resistance to Attack}

Part of the strength of the privilege as a weapon lies in the difficulty of successfully challenging its assertion. An assertion of privilege may be attacked and a response compelled when the response would not incriminate, or when prosecution of the invoker for the crimes for which his response incriminates him is barred by the attachment of jeopardy, the running of the statute of limitations, or past grants of immunity. As we shall see, however, most assertions of privilege prove highly resistant to attack.

\section{Attacking on the Ground that the Response Will not Incriminate}

The plaintiff may attack a claim of privilege by defendants or their employees on the ground that the invoker's response would not in fact tend to incriminate. But a combination of principles from past cases $^{39}$ all but ensure that the court will not be able to overrule the claim on this ground. Of course, the invoker's claim that his response may tend to incriminate is not enough; the court must decide that the response may incriminate. ${ }^{40}$ But this principle has lost any practical significance in light of the standards the court must apply.

The first standard operating in favor of the invoker is a broadly inclusive notion of incriminating responses. Currently, a response "tends to incriminate" as long as it might provide a clue leading investigators to discover facts that could constitute links in a chain of circumstantial evidence

38. See de Antonio v. Solomon, 42 F.R.D. 320, 322 (D. Mass. 1967) ("Such a sanction would make the assertion of that privilege indeed 'costly,' and would be the kind of watering down of the privilege which the Supreme Court has clearly proscribed.") The court in de Antonio borrowed indirectly from Griffin v. California, 380 U.S. 609 (1965). Justice Douglas, writing for the Court, there pointed out that allowing the prosecutor to comment on the defendant's refusal to testify under the privilege against self-incrimination violated that privilege since such comment "cuts down on the privilege by making its assertion costly." Id. at 614.

39. Hoffman v. United States, 341 U.S. 479 (1951), and United States v. Coffey, 198 F.2d 438 (3d Cir. 1952), are the most notable cases establishing the standards that govern when Fifth Amendment claims are challenged. See also Malloy v. Hogan, 378 U.S. 1, 11-12 (1964) (reaffirming Hoffman); Emspak v. United States, 349 U.S. 190, 198 n.18 (1955) (approving Coffey).

40. See Hoffman v. United States, 341 U.S. 479, 486 (1951); Malloy v. Hogan, 150 Conn. 220, 224-25, 187 A.2d 744, 747 (1963), rev'd on other grounds, 378 U.S. 1 (1964); In re Petty, 18 Utah 2d 320, 324, 422 P.2d 659, 661-62 (1967). But see David Webb, Inc. v. Rosenstiel, 66 Misc. 2d 29, 33, 319 N.Y.S.2d 877, 881 (Sup. Ct. Special Term 1970) ("[T]he witness is the best judge of whether an answer will tend to incriminate him, since he is obviously in possession of more facts than are known to the court or other parties....") 
proving the invoker's criminal conduct. ${ }^{41}$ Finding any responses to be wholly free of an incriminating potential under this standard is difficult. ${ }^{42}$ For instance, a response that denies wrongdoing and provides exculpatory information may tend to incriminate by helping the government pinpoint more fruitful areas of inquiry. ${ }^{4}$ Determining whether responses will tend to incriminate, therefore, requires predictions not only about possible inferences from circumstantial evidence but also about possible investigatory paths. Yet at the time the court must decide the plaintiff's challenge, which may be early in the case, the information needed for these predictions is not likely to be available.

The second principle undermining the court's ability to overrule an assertion of the privilege forbids the court from requiring the invoker to tell the court what his response would be. Revealing his response-even in an in camera hearing-would, the courts say, "surrender the very protection which the privilege is designed to guarantee." 44 Thus, courts must in ef-

41. Hoffman v. United States, 341 U.S. 479, 486 (1951); Coffey v. United States, 198 F.2d 438, 440 (3d Cir. 1952); Allen v. Superior Court, 18 Cal. 3d 520, 524, 557 P.2d 65, 66, 134 Cal. Rptr. 774,775 (1976).

The breadth of this standard becomes apparent when compared with the less inclusive standards rejected. For instance, one might consider incriminating only responses that amount to confessions, in that they admit all elements of a crime. Or one might narrow the standard even further by including only responses that provide information likely to be helpful to the government. Under this narrow approach, responses that admit complete crimes but that are likely only to provide cumulative evidence, for example, would not be considered incriminatory. On occasion the Supreme Court has suggested that it may move toward such a standard. In Fisher v. United States, 425 U.S. 391 (1976), for example, the taxpayer sought to avoid compliance with a subpoena for certain documents in his possession. In requiring compliance, the Court stated: "The existence and location of the papers are a foregone conclusion and the taxpayer adds little or nothing to the sum total of the Government's information by conceding that he in fact has the papers." Id. at 411.

Another approach might consider incriminating responses admitting some but not all elements of a crime. A still more inclusive approach might encompass responses that provide only "a link in a chain of evidence" showing criminal conduct. See Maness v. Meyers, 419 U.S. 449, 461 (1975); Blau v. United States, 340 U.S. 159, 161 (1950).

42. Because responses providing only a link in the chain may be innocuous on their face, analysis of the incriminatory character of the response requires a good deal of information about the background of the crime and the other circumstantial evidence by which the crime might be shown. E.g., In re Atterbury, 316 F.2d 106, 109-110 (6th Cir. 1963) (trial court erred in refusing to allow witnesses to show circumstances that made testimony demanded of him self-incriminatory); In re Portell, 245 F.2d 183, 185 (7th Cir. 1957) (trial court erred in excluding from evidence newspaper clippings showing how witness's testimony would be self-incriminating); Ballantyne v. United States, 237 F.2d 657, 664-65 (5th Cir. 1956) (reviewing prior statements of witness to IRS agents and grand jury to conclude that answering grand jury questions would incriminate witness).

43. See Noonan, Inferences from the Invocation of the Privilege Against Self-Incrimination, 41 VA. L. REV. 311, 328-31 (1955); Ratner, Consequences of Exercising the Privilege Against SelfIncrimination, 24 U. GHI. L. REV. 472, 489-93 (1957). Cf. Miranda v. Arizona, 384 U.S. 436, 477 (1966) ("[N]o distinction may be drawn between inculpatory statements and statements alleged to be merely 'exculpatory.' . . . In fact, statements merely intended to be exculpatory by the defendant are often used to impeach his testimony at trial or to demonstrate untruths in the statement given under interrogation and thus to prove guilt by implication.")

44. Hoffman v. United States, 341 U.S. 479, 486 (1951). As Judge Learned Hand observed:

Obviously a witness may not be compelled to do more than show that the answer is likely to be

dangerous to him, else he will be forced to disclose those very facts which the privilege protects. 
fect apply the highly inclusive standard for an incriminating response to an unknown response.

To be sure, courts require the invoker to show the incriminating potential of his response. ${ }^{45}$ But another principle comes to the invoker's aid and all but guarantees that the requirement will be met: the incriminatory potential of the response may be shown merely by argument, and without evidence. ${ }^{46}$ In practice, the invoker's attorney need only sketch a scenario of how a possible but still unknown response might provide direct or circumstantial evidence of criminal conduct or clues leading to evidence of criminal conduct.

The ease of showing the incriminatory potential of a possible response is best appreciated if a fourth principle is kept in mind: a person need not believe himself guilty of criminal conduct to invoke. Because the privilege extends to any incriminating "evidence," the invoker may claim its protection as long as he believes his response may help a prosecutor mount a case, however misguided, against him. A court therefore may be required to uphold an invocation of privilege even when the invoker insists he has never committed a crime. ${ }^{47}$ Logically-although no opinions have reached this issue-the invoker's attorney should prevail as long as he can fit a possible response into a plausible, though mistaken, chain of evidence that a future prosecutor might devise.

Another principle operating to ensure success for the claim that the response might incriminate gives the benefit of any doubt to the invoker. In the Supreme Court's words, a response may not be compelled unless it is " 'perfectly clear, from a careful consideration of all the circumstances in the case, that the witness is mistaken, and that the answer[s] cannot possibly have such tendency' to incriminate." ${ }^{\text {"48 }}$ Considering the maze of predic-

Logically, indeed, he is boxed in a paradox, for he must prove the criminatory character of what it is his privilege to suppress just because it is criminatory.

United States v. Weisman, 111 F.2d 260, 262 (2d Cir. 1940). Of course, the judge and the party seeking to show that the response would not incriminate are also boxed into this paradox.

Professor Westen has pointed out that with all other privileges the court can compel the witness to disclose his response in camera. Westen, Confrontation and Compulsory Process: $A$ Unified Theory of Evidence for Criminal Cases, 91 HARV. L. REV. 567, 581 n.38 (1978). An in camera proceeding for assessing Fifth Amendment privilege claims, however, is "less feasible." Id. But see United States v. Melchor Moreno, 536 F.2d 1042, 1047 \& n.7 (5th Cir. 1976) (dictum) (in camera hearing may afford witness protection equivalent to statutory immunity, although issue is a "difficult one").

45. See supra p. 1071.

46. See Hoffman v. United States, 341 U.S. 479, 486-87 (1958); Capitol Prods. Corp. v. Hernon, 457 F.2d 541, 544 (8th Cir. 1972); Isaacs v. United States, 256 F.2d 654, 658-60 (8th Cir. 1958); United States v. Coffey, 198 F.2d 438, 440 (3d Cir. 1952). Even an explanation of how the response could be incriminatory may not be required if such an explanation would result in incriminatory disclosure. See In re Ippolito, 75 N.J. 435, 441, 383 A.2d 117, 120 (1978).

47. See Grunewald v. United States, 353 U.S. 391, 421 (1957); Ullman v. United States, 350 U.S. 422, 426-28 (1956).

48. Hofiman v. United States, 341 U.S. 479, 488 (1951) (quoting Temple v. Commonwealth, 75 Va. 892, 898 (1881)) (emphasis deleted); see In re Atterbury, 316 F.2d 106, 110 (6th Cir. 1963); 
tive judgments involved in deciding whether even a known response will "tend to incriminate" under one or another of the available grounds, doubt is one thing the Court should expect. The sources of doubt abound; there is doubt about the possible responses, the possible crimes, the possible evidentiary chains, and the possible investigatory paths. There may also be doubt about the application of the law to known conduct. In antitrust cases, for example, witnesses may claim that although they always believed their conduct to be innocent, the uncertain reach of the antitrust laws leads them to invoke the privilege as a safety measure. ${ }^{49}$

This combination of principles, at least in cases where civil liability springs from criminal conduct, gives defendants and their employees faced with requests for information a virtual option to invoke. ${ }^{50}$ Since these principles were embraced, reported decisions finding that the invoker's response would not tend to incriminate have been rare indeed. ${ }^{51}$

Even if the plaintiff occasionally satisfies the court that the invoker's response could not possibly incriminate him, the victory may be pyrrhic. For the privilege could be invoked again in response to each separate question or request for information. ${ }^{52}$ The expense of challenging each claim will often exceed the benefit the plaintiff derives from the response on that rare occasion when his challenge is successful.

Nothing said here, it should be emphasized, is meant to criticize the legal standards now applied when invokings are challenged. Responses providing clues need to be protected to keep the privilege meaningful. Putting greater burdens on the invoker may undermine the purpose of the

United States v. Miranti, 253 F.2d 135, 139 (2d Cir. 1958); C. MCCORMICK, EVIDENCE $\S 139$, at 295 (2d ed. 1972).

49. This claim is most plausible in rule of reason antitrust cases. In these cases, ironically, the policies of enforcement officials remove any practical danger of prosecution. See supra note 12. Even in civil price-fixing cases, however, the invoker who claims to be innocent can assert that the uncertain legality of exchanges of price information, for example, requires him to invoke. The uncertain legality of exchanges of price information can be seen by comparing United States v. United States Gypsum Co., 438 U.S. 422 (1978), with United States v. Container Corp., 393 U.S. 333 (1969).

50. In fact, a stringent waiver rule holding that one who provides facts waives the privilege as to details encourages invoking at the earliest opportunity. See Brown v. United States, 356 U.S. 148 (1958); Rogers v. United States, 340 U.S. 367 (1951).

51. At the Supreme Court level, Fisher v. United States, 425 U.S. 391 (1976), and Zicarelli v. New Jersey State Comm'n of Investigation, 406 U.S. 472 (1972), are two such cases. In contrast, numerous circuit court opinions that overruled claims of privilege have been reversed per curiam. E.g., Simpson v. United States, 241 F.2d 222 (9th Cir. 1957), rev'd per curiam, 355 U.S. 976 (1959); United States v. Trock, 232 F.2d 839 (2d Cir. 1956), rev'd per curiam, 351 U.S. 976 (1956); United States v. Singleton, 193 F.2d 464 (3d Cir.), rev'd per curiam, 343 U.S. 944 (1952); United States v. Greenberg, 192 F.2d 201 (3d Cir. 1951), rev'd per curiam, 343 U.S. 918 (1952).

52. In civil cases one must ordinarily invoke the privilege question by question. See Hudson Tire Mart v. Aetna Casualty \& Surety Co., 518 F.2d 671, 674 (2d Cir. 1975); In re Pcnn Cent. Sec. Litig., 347 F. Supp. 1347, 1348 (E.D. Pa. 1972). Only in rare instances will a blanket refusal to testify be upheld. See, e.g., Priebe v. World Ventures, Inc., 407 F. Supp. 1244, 1246 (C.D. Cal. 1976) ("Here ... any proper question in the civil context inherently gives rise to self-incrimination hazards.") 
privilege. But the likelihood that current standards will persist for lack of better ones only underscores the need to appreciate the obstructive potential of the privilege.

\section{Attacking on the Ground that Prosecution is Barred by Double Jeopardy}

The plaintiff may claim that the privilege cannot be invoked because prosecution of the invoker for crimes revealed by his response is barred by the prohibition on double jeopardy. In practice, however, the double jeopardy rule offers the plaintiff no help. Even if the invoker has already been prosecuted, he will almost always be able to point to some crime for which his response may tend to incriminate him and to which jeopardy has not attached.

The threat of prosecution may exist despite previous prosecution if the conduct at issue is subject to the criminal sanctions of more than one jurisdiction. Securities fraud, for example, is often a state as well as a federal offense. ${ }^{53}$ In fact, the potential for geographically widespread effects will often render an instance of fraud subject to the jurisdiction of several states. ${ }^{54}$ Under double jeopardy standards, prosecution by one jurisdiction does not bar prosecution by any other. ${ }^{55}$ Hence one previously convicted of securities fraud will be able to invoke the privilege in a private civil action

53. Compare 15 U.S.C. $\$ 77$ e (1976) and S.E.C. Rule 10b-5, 17 C.F.R. \$ 240, 10b-5 (1981) with COLO. REV. STAT. $§ 11-51-124$ (Supp. 1981) and UNIF. SECURITIES ACT $\S \S 101,409,7$ U.L.A. 568, 665 (1958).

Antitrust is another area of overlapping state and federal criminal law. Compare 15 U.S.C. $\$ \S 1-2$ (1976) with CAL. BUS. \& PROF. CODE $\$ \S 16,700-16,758$ (West 1981 \& Supp. 1982); ILL. ANN. STAT. ch. 38, I60 (Smith-Hurd Supp. 1980); and CoLO. REV. STAT. \$§ 6-4-101 to -109 (1973 \& Supp. 1981). All states but Connecticut impose some criminal sanction for antitrust violations.

54. Section 414 of the Uniform Securities Act, which has been substantially adopted in approximately 35 states, makes clear that the criminal provisions of a state's Blue Sky Law may apply to a seller of securities who has not performed within the state every act necessary to complete the offense, and even to a person who has never been in the state. Of course, the seller's conduct may also subject him to criminal liability in the state where he resided and in which the acts occurred. Thus a seller residing in one state who is guilty of fraudulent misrepresentation in a sale to a buyer residing in a second state is subject to separate prosecutions under the Blue Sky Laws of both states. UNIF. SECURITIES ACT \& 414(a)-(f) Commissioners' Note, 7 U.L.A. 692-93 (1958).

A state will obtain jurisdiction rather easily even when much of the conduct at issue occurred elsewhere. E.g., Frasher v. State, 8 Md. App. 439, 260 A.2d 656 (Md. Ct. Spec. App. 1970) (defendant possessing narcotics who was forcibly brought into Maryland could then be prosecuted for possession of contraband even if another jurisdiction had already prosecuted for same crime). A single price-fixing conspiracy could also subject the conspirators to prosecution by many states as well as by the federal government. See Sims, Two Bites At the Apple?-Double Jeopardy and the Antitrust Laws, 48 ANTITRUST L.J. 1401, 1412 (1979).

55. See Abbate v. United States, 359 U.S. 187 (1959) (indictment and guilty plea under state statute outlawing destruction of property of another does not preclude prosecution based on same conspiracy under federal statute outlawing destruction of federal communications facilities); Bartkus v. Illinois, 359 U.S. 121, 127-39 (1959) (trial and acquittal under federal bank robbery statute did not preclude prosecution on substantially the same evidence under state robbery statute). See also United States v. Wheeler, 435 U.S. 313 (1978) (prosecution by Indian tribe does not bar federal prosecution). 
based on the same conduct, such as a stockholders' derivative suit, as long as one jurisdiction that is able to prosecute has not done so. ${ }^{56}$ That further prosecution is unlikely because prosecutors have adopted policies against duplicating prosecutions by other jurisdictions is, as we have seen, immaterial. ${ }^{57}$

The double jeopardy challenge to an invocation of privilege will also be foreclosed whenever the invoker's response would tend to incriminate him for a crime other than the one for which he was prosecuted. For instance, an invoker who claims his response would incriminate him of conspiring to fix the prices of one product may always claim, once he has been prosecuted for that conspiracy, that his response would also incriminate him of closely related price-fixing conspiracies involving slightly different products, customers, regions of the country, co-conspirators, or time periods. Such differences may render the conspiracies separate crimes. ${ }^{58}$ Because determining whether the conspiracies are separate crimes may require a full presentation of the facts, the court will often be in no position to evaluate the invoker's claim when it arises early in the civil case. ${ }^{59}$

An invoker previously prosecuted for price-fixing may claim that his response might also provide evidence of crimes that consist in part of price-fixing but that require additional elements. ${ }^{60}$ At the federal level,

56. Assertions of privilege have been upheld on numerous occasions despite conviction on federal criminal charges because the possibility of prosecution by other jurisdictions remained open. E.g., United States v. Stephens, 492 F.2d 1367, 1374 (6th Cir. 1974); United States v. Seavers, 472 F.2d 607 (6th Gir. 1973). A limited exception is that the possibility of prosecution by a foreign government under its laws will not necessarily sustain a privilege claim. See In re Grand Jury Proceedings, 532 F.2d 404, 407 (5th Cir. 1976); In re Parker, 411 F.2d 1067 (10th Cir. 1969). But see In re Cardassi, 351 F. Supp. 1080 (D. Conn. 1972) (refusing to compel witness who had received use immunity to answer grand jury questions because of likelihood of prosecution by Mexico).

57. See supra p. 1066 (privilege still available despite policy of prosecutors against prosecuting crime that response would tend to reveal). The United States Department of Justice, for example, has a longstanding policy against duplicating state prosecutions. See Petite v. United States, 361 U.S. 529, 531 (1960) (per curiam); U.S. DEP'T OF JUSTICE, UNITED STATES ATTORNEYS' MANUAL \$\$ 9-2.142 to .143 (Jan. 3,1980 ). The so-called "Petite policy" opposes federal prosecution, after a state prosecution based on the same act, in the absence of a compelling federal interest. See generally Note, The Petite Policy: An Example of Enlightened Prosecutorial Discretion, 66 GEo. L.J. 1137 (1978) (discussing policy). But despite the Petite Policy, conviction at the state level does not bar assertion of the privilege, since the possibility of federal prosecution remains.

58. Kotteakos v. United States, 328 U.S. 750, 755 (1946), provides some guidance for determining whether conspiracies are separate crimes. Quoting with approval from the Court of Appeals, the Supreme Court drew an apt analogy: "Thieves who dispose of their loot to a single receiver-a single 'fence'-do not by that fact alone become confederates: they may but it takes more than knowledge that he is a fence to make them such." Id. at 755. See also United States v. Sarullo, 510 F.2d 1174, 1178 (6th Cir. 1975) (that victims differ tends to show separate conspiracies); United States v. Arnold, 336 F.2d 347, 351 (9th Cir. 1964) (whether conspiracies to import narcotics are separate is jury question); United States v. American Honda Motor Co., 273 F. Supp. 810, 816 (N.D. Ill. 1967) (that defendants' conduct contributes to single goal tends to show single conspiracy).

59. Many courts have found they can only decide whether conspiracies are separate after the trial. E.g., United States v. Young, 503 F.2d 1072, 1077 n.17 (3d Cir. 1974); United States v. Wilshire Oil Co., 427 F.2d 969, 975-77 (10th Cir. 1970).

60. Cf. Gore v. United States, 357 U.S. 386, 389-90 (1958) (single narcotics sale could subject 
such crimes include mail fraud, racketeering, felony conspiracy, and wire fraud. ${ }^{61}$ Often the invoker will also be able to point to state crimes that consist in part of price-fixing. With each of these offenses, the invoker may be prosecuted for the substantive offense itself and thereafter prosecuted for conspiracy to commit that offense, since jeopardy would not attach initially to the conspiracy charge. ${ }^{62}$ Furthermore, if the invoker has testified in an earlier proceeding, he may claim his response would provide evidence that he committed perjury during that previous testimony.

The previously convicted invoker may also point to the possibility that his response will be admitted as "other crimes" evidence in future prosecutions against him for a wide range of crimes. Evidence of his past pricefixing may be admissible in a prosecution for other crimes under many different theories. ${ }^{63}$ If, for example, the invoker's response would indicate he always demanded that price-fixing conspiracy meetings be held at 8:00 A.M. in the Executive Room at the Hilton Hotel, the response, by showing his particular modus operandi, might be used to identify him as the person making a similar demand in a bribery conspiracy. ${ }^{64}$ As long as prosecution for the bribery conspiracy is not barred by double jeopardy, the privilege may be invoked in the civil price-fixing suit, even though the invoker has already been prosecuted for his price-fixing conduct.

The invoker may further claim that his response, by providing evidence of past price-fixing, ${ }^{65}$ will provide clues that may lead to evidence of other crimes. In the example above, for instance, the invoker can claim that his

defendant to consecutive punishment under three different federal laws since Congress intended these laws to punish distinct offenses); American Tobacco Co. v. United States, 328 U.S. 781, 787-89 (1946) (same conduct in restraint of trade may satisfy some elements of violation of $\S 1$ and 2 of Sherman Act); United States v. Marotta, 518 F.2d 681, 684-85 (9th Cir. 1975) (single chain of events resulted in prosecution of defendant for conspiracy to import and conspiracy to possess with intent to distribute narcotics). See generally Blockburger v. United States, 284 U.S. 299, 304 (1932) (offenses differ for purposes of double jeopardy if each requires proof of fact not required by the other).

61. See 18 U.S.C. $\S 371$ (1976) (felony conspiracy); id. $\S 1341$ (mail fraud); id. $\S 1343$ (wire fraud); id. \$1962 (racketeering).

62. Sec United States v. Johnson, 488 F.2d 1206, 1209 (1st Cir. 1973); United States v. Chase, 281 F.2d 225, 229 (7th Cir. 1960); United States v. Ward, 314 F. Supp. 261 (E.D. La. 1970); cf. United States v. Maranti, 253 F.2d 135, 138-39 (2d Cir. 1958) (jeopardy on conspiracy count does not bar prosecution for substantive offense).

63. FED. R. EVID. 404(b), for example, provides that evidence of other crimes may be admissible to show motive, opportunity, intent, preparation, plan, knowledge, identity, or absence of mistake or accident.

64. Cf. United States v. Serlin, 538 F.2d 737, 747 (7th Cir. 1976) (prior similar acts admitted to show intent); United States v. Jones, 438 F.2d 461, 466 (7th Cir. 1971) (prior acts showed that earlier schemes "bore a singular strong resemblance to the pattern of the offense charged").

65. This discussion has assumed that the invoker indicates his response would tend to show pricefixing conduct for which he has been prosecuted. But some courts do not require the invoker even to identify the crimes for which his response will tend to incriminate him. E.g., Triangle Publications v. Ferrare, 4 A.D.2d 591, 168 N.Y.S.2d 128 (N.Y. App. Div. 1961) (privilege claim upheld without indication of crimes for which response would incriminate). This uncertainty compounds the difficulties facing a plaintiff who must show that the provision against double jeopardy bars use of the response in any future prosecution. 
response will provide a clue leading a future detective to investigate the other meetings the invoker attended in that hotel room. Such investigations, the invoker can claim, will lead to evidence of other crimes. Thus, the range of crimes for which a response might provide a clue is broad indeed. Jeopardy will hardly have attached to them all.

\section{Attacking on the Ground that Prosecution is Barred by the Statute of Limitations}

Assuming the court is able to identify the crimes for which the invoker's response may tend to incriminate him, his invoking should be overruled if the statutes of limitations for prosecuting those crimes have run. Of course, if the response would tend to incriminate the invoker in several jurisdictions, the statutes of limitations must have run in all of those jurisdictions.

A threshold problem is that the court may not know enough about the supposed criminal conduct - which the invoker may claim did not actually occur-to ascertain which states might have jurisdiction to prosecute or when that conduct took place. Because the plaintiff carries the burden of proving that the limitations period has run, any doubts will be resolved in the invoker's favor. ${ }^{.6}$

Even when the dates of the possible crimes and the jurisdictions able to prosecute are clear, other problems may arise. Consider again a suit for damages arising from the defendants' price-fixing. The federal statute of limitations for price-fixing is five years. ${ }^{67}$ The state statutes of limitations vary; some allow prosecution indefinitely. ${ }^{68}$ But the statutorily imposed limitations period matters little in price-fixing conspiracies. At least under federal law, such conspiracies are presumed to continue, and the statute of limitations does not begin to run in favor of any conspirators until they "disavow or defeat the purpose" of the conspiracy. ${ }^{69}$ This may be accomplished by alerting law enforcement officials to the conspiracy or by announcing one's withdrawal from the conspiracy to the co-conspirators. ${ }^{70}$

66. See United States v. Goodman, 289 F.2d 256, 262-63 (4th Cir. 1961).

67. 18 U.S.C. $\S 3282(1976)$.

68. E.g., OHIO REV. CODE ANN. § 1331.12 (Page 1979); see also Ohio ex rel. Brown v. Klosterman French Baking Co., 1977-1 Trade Cas. (CCH) I 61,361, at 71,273 (S.D. Ohio 1976) (upholding constitutionality of Ohio's indefinite limitations period).

69. Hyde v. United States, 225 U.S. 347, 369 (1912); see United States v. Pearson, 508 F.2d 595, 597 (5th Cir. 1975); United States v. Nowak, 448 F.2d 134, 139 (7th Cir. 1971), cert. denied, 404 U.S. 1039 (1972); United States v. Roselli, 432 F.2d 879, 905 (9th Cir. 1970).

70. See Hyde v. United States, 225 U.S. 347, 369-70 (1912) (alerting law enforcement officials); United States v. Borelli, 336 F.2d 376, 389 (2d Cir. 1964) (announcing withdrawal to co-conspirators), cert. denied, 379 U.S. 960 (1965). See generally United States v. Colasurdo, 453 F.2d 585, 597 (2d Cir. 1971) (invocation of Fifth Amendment privilege by defendant did not constitute affirmative action required to withdraw from conspiracy). 
An unrepentant conspirator may in theory be prosecuted even when his price-fixing conduct occurred much more than five years in the past. Hence the court in the private civil case would need to know a great deal about the invoker's price-fixing conduct in order to decide if and when the various statutes of limitations had even begun to run in his favor. Yet the court may lack any feasible way to acquire this information at the time an assertion of privilege is challenged. In fact, some courts in conspiracy cases conclude that the jury must ultimately determine statute of limitations claims."

Other arguments for the invoker virtually eliminate any chance that his privilege claim will be overruled on the ground that all statutes of limitations have run. Even if the invoker cannot be prosecuted for the criminal conduct his response would admit because all statutes of limitations concerning that conduct have run, he may claim that his conduct might constitute evidence against him in a prosecution for more recent criminal conduct. For instance, price-fixing conduct occurring outside the limitations period can be admitted in evidence for various purposes in timely prosecutions for later price-fixing. ${ }^{22}$ Similarly, such earlier conduct may provide evidence in prosecutions for later mail fraud, racketeering, or other crimes that consist in part of price-fixing. It may also provide "other crimes" evidence admissible under the Federal Rules of Evidence to show a broad range of later crimes. ${ }^{73}$ Furthermore, the invoker's response may provide evidence that he perjured himself within the limitations period. If all else fails, the invoker may claim that his response would at least provide a clue that would lead investigators to find evidence of other crimes for which the limitations period has not run.

In order to overrule a privilege claim because the statute of limitations has run, the court must be able to dismiss with confidence all of these theories under which the invoker's response may tend to incriminate him. Once again, however, the information needed for this confidence is not likely to be available at the time the invocation is challenged; if it is available, it is likely to be hotly disputed. Moreover, the difficult-if not impossible-task of evaluating a challenge based on the running of the statute of limitations may need to be repeated for each question in response to

71. E.g., United States v. Heckman, 479 F.2d 726, 729 (3d Cir. 1973); United States v. Borelli, 336 F.2d 376, 389 (2d Gir. 1964), cert. denied, 379 U.S. 960 (1965).

72. E.g., In re United Shoe Mach. Corp., 7 F.R.D. 756, 757 (D. Mass. 1947); cf. United States v. Brandom, 479 F.2d 830, 831 n.1 (8th Cir. 1973) (acts occurring outside limitations period admissible in mail fraud prosecution). The earlier conduct may be admissible to show, for example, the conspiracy's origin, see Heike v. United States, 227 U.S. 131, 145 (1913); Continental Baking Co. v. United States, 281 F.2d 137, 154 (6th Cir. 1960), or its purpose, see United States v. Ashdown, 509 F.2d 793, 798 (5th Cir. 1975).

73. See supra note 63 . 
which the privilege is invoked. ${ }^{74}$

\section{Attacking on the Ground that Prosecution is Barred by Past Grants of Use Immunity}

Sometimes the invoker in the civil case has previously received use immunity for his testimony in an earlier prosecution or civil proceeding involving the government. Such immunity may have been conferred in order to compel responses to inquiries similar to those put by plaintiffs in civil cases. If the plaintiff can establish that any future prosecutorial use of the invoker's possible responses has been foreclosed by this immunity, the privilege claim could be overruled and a response compelled.

But this form of attack on the privilege should also fail. Since the replacement of transactional immunity with use immunity, ${ }^{75}$ future prosecution of the invoker is always a theoretical possibility provided the government makes no use, directly or indirectly, of the responses it compelled with its immunity order. ${ }^{76}$ Because the immunity order does not apply to the invoker's responses in the private civil suit, those incriminatory responses could always in theory be used to prosecute him.

Recently some courts have struggled to find that grants of use immunity in previous actions or proceedings necessarily foreclose prosecutorial use of whatever testimony the invoker may give in the private civil case." Such findings would allow the invoker's testimony to be compelled without any involvement by the government. This "prospective taint" approach is a tribute to the ingenuity of judges who realize the obstructive potential of the privilege and the lack of any realistic danger to the invoker who has been given use immunity in an earlier proceeding. Because the approach represents a remedial response to the problems created by the full exploitation of the privilege under conventional notions of use immunity, it is evaluated together with other remedies in Part III below.

74. In that rare instance when the court can overrule the privilege claim because the statute of limitations prevents use of the response in any criminal case against the invoker, the response compelled is likely to be too dated to be of use in the plaintiff's civil action. A private action under the Sherman Act, for example, is subject to a four year limitations period, see 15 U.S.C. § 15b (1976), although the Hyde principle, see supra p. 1078, and the possibility that the government action will toll the statute may extend the limitations period significantly.

75. See United States v. Kuehn, 562 F.2d 427, 430-32 (7th Gir. 1977); United States v. First W. State Bank, 491 F.2d 780, 786 (8th Cir.), cert. denied, 419 U.S. 825 (1974); 18 U.S.C. § 6002 (1976).

76. Kastigar v. United States, 406 U.S. 441 (1972). In Kastigar the Supreme Court upheld the constitutionality of the use immunity statutes only because they prevented any use of the compelled response in a prosecution against the invoker. As long as any direct or indirect prosecutorial use of the response in the civil suit is possible, whether as evidence, clues, or guides to strategy, the invoking must be sustained. See also New Jersey v. Portash, 440 U.S. 450, 456-57 (1979); Murphy v. Waterfront Comm'n, 378 U.S. 52, 79 (1964); Ullmann v. United States, 350 U.S. 422, 430 (1956).

77. See infra pp. 1100-02. 


\section{Advantages Secured by the Privilege}

The privilege's many opportunities for use and its resistance to attack render it a potent weapon in the hands of civil defendants. By invoking at every opportunity, defendants and their employees can prevent plaintiffs from obtaining any discovery from them, except for the documents plaintiffs will admittedly obtain from defendant corporations. Worse, those who invoke during discovery may convince the court at trial that since they plan to invoke again the plaintiff should not be allowed to call them to testify or to inform the jury that they had invoked previously. ${ }^{78}$ Worse yet, if the plaintiff manages to establish a prima facie case at trial through other evidence, those who invoked earlier may then waive the privilege in order to testify as defense witnesses. ${ }^{79}$

A defense strategy calling for defendants and their officers and employees to invoke at every opportunity before trial yields several other advantages. By forcing plaintiffs to seek evidence from sources other than the defendants and their staffs, it increases plaintiffs' expenses and delays their progress. ${ }^{80}$ Such delays, in addition to their usual benefits, enable

78. There is substantial support for the notion that attorneys and judges should not allow the factfinder to learn that a witness has invoked or plans to invoke the privilege. Proposed Rule 513 of the Federal Rules of Evidence provided:

(a) Comment or inference not permitted. The claim of a privilege, whether in the present proceeding or upon a prior occasion, is not a proper subject of comment by judge or counsel. No inference may be drawn therefrom.

(b) Claiming privilege without knowledge of jury. In jury cases, proceedings shall be conducted, to the extent practicable, so as to facilitate the making of claims of privilege without the knowledge of the jury.

(c) Jury instruction. Upon request, any party against whom the jury might draw an adverse inference from a claim of privilege is entitled to an instruction that no inference may be drawn therefrom.

Rules of Evidence for United States Courts and Magistrates, 56 F.R.D. 183, 260 (1973). Congress rejected Proposed Rule 513 on unrelated grounds. See 2 J. WEINSTEIN \& M. BERGER, WEINSTEIN'S EVIDENCE $\S 501[01]-[02]$ (1981). Among the states that have enacted Proposed Rule 513 are Arkansas, Montana, Nebraska, New Mexico, North Dakota, Oklahoma and South Dakota. Id.

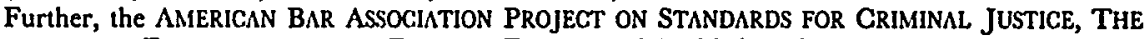
PROSECUTION FUNCTION AND THE DEFENSE FUNCTION $\$ 7.6(c)$ (1970) provides:

(c) It is unprofessional conduct for a lawyer to call a witness who he knows will claim a valid privilege not to testify, for the purpose of impressing upon the jury the fact of the claim of privilege.

79. When witnesses who invoke at a deposition try to waive the privilege at trial, the plaintiff must hope the judge will use his discretion to bar their trial testimony or at least to require them to submit first to a deposition at which they waive the privilege. The latter approach, however, puts the plaintiff in a worse position than if the deponents had waived the privilege earlier, for he may lack the time after this eleventh-hour deposition to prepare an effective attack on the ensuing trial testimony. This possibility of delayed waiver adds an element of uncertainty that works to the defendant's advantage. See infra pp. 1130-31.

80. Of the "dilatory and obfuscatory practices that now apparently flourish" in civil antitrust litigation, NATIONAL COMMISSION FOR THE REVIEW OF ANTITRUST LAWS AND PROCEDURES 27 (1979), use of the privilege against self-incrimination is one of the worst. Yet these private antitrust actions contribute significantly to an effective national antitrust policy. The plaintiff, as a "private attorney general," is seeking to redress not just a private wrong but a public wrong. NATIONAL COMMIISSION TO STUDY THE ANTITRUST LAWS, REPORT OF THE ATTORNEY GENERAL 242 (1955). 
invokers siding with the defense to buy time in which to decide whether to waive the privilege and testify. If they do decide to testify and submit to depositions, the delays will have allowed them to see the other evidence the plaintiff has gathered and to tailor their versions of events accordingly. By limiting plaintiffs' discovery and increasing their risk of failure, this defense strategy also puts plaintiffs in a poor position to negotiate a favorable settlement or prepare for trial.

The strategy may also yield less direct benefits. For instance, it may sharply reduce the expenses, especially in attorney and employee time, that defendants incur in responding to plaintiffs' discovery. It may also contain the disruptive impact of plaintiffs' case on the day-to-day operations of a defendant company.

Should a plaintiff push on to trial, the strategy may cause a failure of proof. In price-fixing conspiracies, for example, the strategy is likely to cause a failure of proof when the defendants and their staffs have kept knowledge of the conspiracy to themselves and have carefully refrained from leaving any evidence of the conspiracy in company documents. In short, defendants' full exploitation of this constitutional privilege may deny plaintiffs any opportunity for meaningful access to the courts, an opportunity that is itself becoming a right worthy of constitutional status. ${ }^{81}$

\section{The Modest Need for the Privilege in Civil Cases}

All evidentiary privileges prevent untrammeled discovery. They undermine to some degree the trial system's capacity to ascertain the truth. ${ }^{82}$ They do so in order to further other policies considered more important. This part briefly examines the extent to which the policies behind the privilege are advanced when the privilege is invoked in private civil cases. Then we may determine whether these policies are offended if the plaintiff is provided some remedy when the privilege is used against him.

The language of the privilege suggests that the Framers intended it to operate only in criminal cases: "No person . . . shall be compelled in any criminal case to be a witness against himself. ${ }^{\prime \prime 83}$ Madison's original lan-

81. See Procunier v. Martinez, 416 U.S. 396, 419-22 (1974) (ban against attorney-client interviews conducted by law students or legal paraprofessionals constituted unjustifiable restriction on inmates' rights of access to courts); California Motor Transp. Co. v. Trucking Unlimited, 404 U.S. 508, 510 (1972) (right of access to courts is one aspect of constitutional right to petition government).

82. Accordingly, the Supreme Court has emphasized the need for narrow interpretation. United States v. Nixon, 418 U.S. 683, 713 (1974) (presidential claim of privilege outweighed by need for evidence in criminal trial); Branzburg v. Hayes, 408 U.S. 665, 690 (1972) (reporters have no First Amendment privilege to conceal facts from grand jury). See also In re Cueto, 554 F.2d 14, 15 (2d Cir. 1977) (lay ministers possess no privilege to refuse to answer grand jury questions).

83. U.S. CONST. amend. V. In contrast, the language of most of the other protections established by the Fifth Amendment, such as the due process guarantee, are not limited by their terms to criminal 
guage, which provided that "no person shall be compelled to be a witness against himself," might have allowed the privilege in civil cases, but it was amended with little debate in the House. ${ }^{84}$ In any event, neither the language of the privilege nor the Framers' intent has governed in Fifth Amendment jurisprudence: "The history of the privilege does not settle the policy of the privilege." ${ }^{\prime 85}$ Because the rule that the privilege must be available in civil cases is now too well settled to admit discussion, ${ }^{86}$ we turn to the policies only to see whether they would be offended by allowing the plaintiff a remedy when the privilege is used against him.

The policies that the privilege has been said to promote ${ }^{87}$ apply with less force in civil cases between private parties than in criminal cases. One purpose of the privilege is to discourage the government from browbeating and torturing criminal suspects in order to obtain confessions. ${ }^{88}$ This goal operates most forcefully when the government's motive for torture or browbeating is keenest. Hence the privilege is needed during station-house

proceedings.

84. A delegate to the Constitutional Convention objected to Madison's clause on these grounds: it contained a general declaration, in some degree contrary to laws passed. He alluded to that part where a person shall not be compelled to give evidence against himself. He thought it ought to be confined to criminal cases, and moved an amendment for that purpose; which amendment being adopted, the clause as amended was unanimously agreed to . . .

1 ANNALS OF CONGRESS 782 (J. Gales ed. 1834).

85. $8 \mathrm{~J}$. WIGMORE, supra note 31, §2251, at 295.

86. See McCarthy v. Arndstein, 266 U.S. 34, 40 (1924). The privilege is also available during legislative investigations, see Watkins v. United States, 354 U.S. 178, 188 (1957), and juvenile proceedings, see In re Gault, 387 U.S. 1, 47 (1967).

87. Many policies have been thought to support the privilege. Justice Goldberg, writing for the Supreme Court in Murphy v. Waterfront Comm'n, 378 U.S. 52, 55 (1964), identified seven: (1) our fear that self-incriminating statements will be elicited by inhumane treatment and abuses; (2) our distrust of self-deprecatory statements; (3) our sense of fair play, which dictates " a fair state-individual balance by requiring the government to leave the individual alone until good cause is shown for disturbing him and by requiring the government in its contest with the individual to shoulder the entire load" " (quoting $8 \mathrm{~J}$. WIGMORE, supra note 31, $\S 2251$, at 317); (4) our preference for an accusatorial rather than an inquisitorial system of criminal justice; (5) our unwillingness to subject those suspected of a crime to the cruel trilemma of self-accusation, perjury, or contempt; (6) our respect for the inviolability of the human personality and of the right of each person " 'to a private enclave where he may lead a private life" "(quoting United States v. Grunewald, 233 F.2d 556, 58182 (2d Cir. 1956) (Frank, J., dissenting), rev'd, 353 U.S. 391 (1957)); and (7) our realization that the privilege, while sometimes a "shelter to the guilty," " is often " 'a protection to the innocent," " (quoting Quinn v. United States, 349 U.S. 155, 162 (1955)). The Court no longer seriously contends that a purpose of the privilege is to protect the innocent. See Tehan v. United States ex rel. Shott, 382 U.S. 406,415 (1966).

As Judge Friendly, among others, has pointed out, the first six stated policies reduce to four: (1) a desire to discourage inhumane treatment and abuses by the government; (2) a desire to maintain the appropriate state-individual balance of advantages; (3) a desire to avoid subjecting persons to the cruel trilemma of self-accusations, perjury, or contempt; and (4) a desire to protect the private enclave. Friendly, The Fifth Amendment Tomorrow: The Case for Constitutional Change, 37 U. CIN. L. REV. 671, 686-87 (1968).

To a large extent later commentators have built on the original analysis of Jeremy Bentham. See Bentham, Rationale of Judicial Evidence, in 7 THE WORKS OF JEREMY BENTHAM 446-47 (J. Bowring ed. 1843).

88. See C. MCCormick, supra note 48, § 118, at 251. 
interrogations of persons in custody; it establishes that a suspect must be told of his right to remain silent and renders any coerced statements and the fruits of such statements inadmissible as evidence. The privilege is also needed during grand jury investigations and criminal trials in order to prevent prosecutors from browbeating witnesses into confessing criminal conduct. In a private civil action, by contrast, the government lacks any opportunity for coercion, and this policy simply does not operate.

The use of the privilege as a prophylactic measure against government browbeating and torture is one of the so-called "foxhunter" policies of the privilege because it aims at influencing the government's methods of investigating and prosecuting crime. ${ }^{89}$ Another fox-hunter policy is to encourage government investigators to gather evidence of criminal conduct supposedly more reliable than confessions. ${ }^{90}$ This policy seeks to spur into action any disciples of that fabled Indian policeman who explained his reliance on confessions as follows: "It is far easier to lie in the shade and rub red pepper in the poor devil's eyes than to go out in the sun hunting for evidence." 91 This policy is furthered in part by preventing the government from requiring criminal defendants to testify and by allowing any person to refuse to incriminate himself when questioned by government investigators.

In one sense this policy does not operate at all in civil cases between private parties. Even if the privilege were not available there, the government would not be the one seeking to compel self-incriminating testimony in order to avoid its burden of independent investigation. In another sense, however, any measures likely to induce potential invokers in a civil case to admit self-incriminating evidence may reduce the government's need to search elsewhere for evidence. ${ }^{92}$ But even assuming there is a policy

89. See O'Brien, The Fifth Amendment: Fox Hunters, Old Women, Hermits, and the Burger Court, 54 NOTRE DAME LAW. 26 (1978).

90. In Garner v. United States, a case upholding the admission in evidence of incriminating disclosures on tax returns, the Court suggested that this policy is not implicated in private civil cases:

[T] he fundamental purpose of the Fifth Amendment [is] the preservation of an adversary sys-

tem of criminal justice. . . . That system is undermined when a government deliberately seeks

to avoid the burdens of independent investigation by compelling self-incriminating disclosures.

In areas where a government cannot be said to be compelling such information, however, there

is no such circumvention of the constitutionally mandated policy of adversary criminal proceedings.

424 U.S. 648, 655-56 (1976) (citation omitted).

91. 1 J. STEPHEN, History OF THE CRIMINAL LAW 442 n.1 (1883).

92. If the privilege were not available at all in civil cases, government investigators would be tempted to pressure persons to sue suspects in order to use the self-incriminatory evidence gathered for subsequent criminal prosecution. But if the government uses civil discovery to circumvent the limits on criminal discovery, the evidence it obtains may be suppressed under the due process clause. E.g., United States v. Parrott, 248 F. Supp. 196, 199-202 (D.D.C. 1965). Cf. Silver v. McCamey, 221 F.2d 873, 874-875 (D.C. Cir. 1955) (administrative license revocation hearing may not be held while criminal charge against same person and arising out of same incident is pending because disclosure of evidence necessary for defense of hearing may prejudice defense of criminal trial). 
against aiding the government in this manner, giving the plaintiff some remedy in a civil case should not produce an undue amount of unreliable self-incriminatory evidence. Persons genuinely concerned about their criminal exposure will probably continue to invoke in the civil case. Moreover, any incriminating testimony a potential invoker gives during civil litigation is more likely to be reliable than the coerced confessions this policy seeks to avoid. The testimony, after all, will be uttered in a relatively formal proceeding by a person who has had time to consider the implications of his statements.

Another fox-hunter policy behind the privilege is to maintain in criminal cases the proper "state-individual balance," a balance that historically removes any burden from the criminal defendant and requires the government "to shoulder the entire load" in establishing guilt.. ${ }^{33}$ The underlying goal is to maintain the adversarial character of criminal procedure. This policy is reflected in the rule, derived from the privilege, allowing the defendant in a criminal case to refuse to take the stand. Taken to the extreme, the policy would allow the accused to refuse to cooperate in any way in his prosecution. He could refuse to appear in lineups or to provide handwriting samples, blood samples, or fingerprints. Nevertheless, all these involuntary actions through which the accused provides evidence incriminating himself have been compelled. ${ }^{94}$ Even "testimonial" incriminatory evidence of minor importance has been compelled..$^{95}$ In short, the policy as stated has never been pushed to its logical limit.

Removing the privilege altogether from private civil cases would not reduce the adversarial character of criminal proceedings. The current procedures and allocation of responsibilities would continue unaltered. To be sure, the broader goal of limiting the government's power over individuals would be affected if the privilege were not available in civil proceedings involving the government. Indeed, if the privilege did not apply in civil tax investigations, deportation hearings, and licensing hearings, for example, government agents conducting these non-criminal proceedings could easily circumvent the adversarial criminal procedures. But even this broader goal of the state-individual policy is not implicated in civil cases between private parties.

The policy that applies with the most force in private civil cases is

93. $8 \mathrm{~J}$. WIGMORE, supra note $31, \S 2251$, at 317.

94. Sce, e.g., Gilbert v. California, 388 U.S. 263, 266, 272 (1967) (handwriting exemplars and appearance in lineup); Schmerber v. California, 384 U.S. 757 (1966) (blood sample); see also Friendly, supra note 87, at 703-05 (discussing constitutionality of taking body evidence); Note, Constitutional Limitations on the Taking of Body Evidence, 78 YALE L.J. 1074 (1969) (same).

95. See, e.g., Fisher v. United States, 425 U.S. 391, 410-414 (1976) (compelling implied admission of possession of accountant's workpapers); California v. Byers, 402 U.S. 424 (1971) (compelling disclosure of name and address after involvement in auto accident). 
known as the "old woman's policy." 96 It reflects the desire to avoid forcing a person to face the "cruel trilemma" of choosing among incrimination, perjury, or contempt. ${ }^{97}$ The privilege allows the person from whom an incriminatory response is sought to escape this trilemma. Of course, if cruelty is the concern, one might question why it is permissible to force parents to incriminate children or to force persons to reveal information that is highly damaging but not incriminatory. Apparently, the "old woman's policy" assumes that forcing self-incriminatory testimony is significantly more cruel than forcing any other testimony. ${ }^{98}$

A defendant or a witness in a civil case who must respond to a discovery request may indeed face this trilemma. He cannot ensure that an incriminatory response will not reach the government and be used to prosecute him. ${ }^{99}$ The cruelty of the trilemma will vary with the circumstances, however. The cruelty will virtually dissolve when the danger of prosecution based on the incriminatory response is remote, for the privilege protects only against penal sanctions. ${ }^{100}$ It does not protect against the cruelty arising from stigmatizing oneself as a criminal or from exposing oneself to civil liability, however massive. ${ }^{101}$ Accordingly, although this policy will sometimes apply with as much force in civil cases as in criminal, it does not apply when the plaintiff is able to establish that the invoker faces no practical danger of prosecution.

The desire to avoid the cruel trilemma suggests another reason for al-

96. The responsibility for this label lies with Bentham. Bentham, supra note 87. Apparently he believed the cruelty of the trilemma facing one whose answer would incriminate himself would only offend old women.

97. Friendly, supra note 87 , at 686 . Professor McNaughton has characterized this policy as the desire to avoid forcing witnesses to "choose among the three horns of the triceratops." McNaughton, supra note 1 , at 147 .

98. In Dean Griswold's words:

[W] do not make even the most hardened criminal sign his own death warrant, or dig his own

grave, or pull the lever that springs the trap on which he stands. We have through the course of history developed a considerable feeling of the dignity and intrinsic importance of the individual man.

Griswold, supra note 1, at 503. See generally O'Brien, supra note 89, at 41-45 (discussing "old woman's policy").

99. Of course the trilemma facing a witness in a civil case would be more cruel, and the foxhunter policies implicated as well, except for the rule that a witness who waives the privilege in the civil case may nevertheless invoke it during a later criminal proceeding. See United States v. Miranti, 253 F.2d 135, 139 (2d Cir. 1958); Stone v. State, 85 Wash. 2d 342, 534 P.2d 1022 (1975); 8 J. WIGMORE, supra note 31 , at $470-72$.

100. Kastigar v. United States, 406 U.S. 441, 453 (1972).

101. A person may not invoke simply because his response would be degrading, subject him to scorn, cause mental anguish, betray a non-privileged confidence, injure friends, or subject him to civil liability, loss of employment, or disqualification from certain professions. The privilege is only available when the response would tend to incriminate. See Ullman v. United States, 350 U.S. 422, 430-31 (1956) (privilege does not protect witnesses from "loss of job, expulsion from labor unions, state registration and investigation statutes, passport eligibility, and general public opprobrium"); Brown v. Walker, 161 U.S. 591, 598 (1896) (answer may be compelled despite its tendency to disgrace witness or bring him into disrepute). 
lowing the privilege at least at civil depositions and trials. Without the privilege, the private counsel asking the questions will be able to browbeat a deponent or a witness in order to force him to confess criminal conduct. Of course, hostile and cruel interrogations often occur at depositions even when the privilege is available. Deponents cross swords with interrogators for many reasons besides fear of incrimination. But browbeating to coerce incriminatory admissions is, according to the policy against the cruel trilemma, a significantly more repulsive spectacle than browbeating for other aims. Nor will it necessarily become less repulsive when the interrogator is a private litigant rather than a public official.

Thus, unlike the other policies behind the privilege, ${ }^{102}$ the "old woman's" policy does apply with significant force in private civil cases. But the cruel trilemma will be avoided as long as the privilege is available in the civil case, regardless of the remedies allowed to reduce the disadvantage to the plaintiff. Since the cruelty this policy seeks to avoid is only the cruelty of being forced to increase one's criminal exposure, remedies for invoking that only increase the civil exposure of the invoker or his employer do not offend any policy behind the privilege.

\section{Remedies}

We have seen that the desire to avoid the "cruel trilemma," if nothing else, requires that the privilege remain available in civil cases. We have also seen, however, that the policies behind the privilege do not preclude devising remedies to help the party who is stymied by its use.

In fact, the willingness of courts to devise remedies has turned less on policy considerations than on whether the invoker is identified with the plaintiff or the defendant. Certainly courts have shown no hesitation to assist defendants when the person invoking the privilege in a civil case is the plaintiff or the plaintiff's employee. ${ }^{103}$ The most common judicial response is to dismiss the plaintiff's action. Indeed, when plaintiffs invoke, most discussions center on whether the action should automatically be dis-

102. At various times the privilege has been said to serve policies besides the "foxhunter" policies and the policy of avoiding the cruel trilemma. Debate has centered on the "hermits" policy, which seeks to protect that "private enclave where [each] may lead a private life." United States v. Grunewald, 233 F.2d 556, 581-82 (2d Cir. 1956) (Frank, J., dissenting), rev'd, 353 U.S. 391 (1957). For a brief period the Court considered this the primary policy of the privilege. See Tehan v. United States ex rel. Shott, 382 U.S. 406, 415-16 (1966); McKay, Self-Incrimination and the New Privacy, 1967 SUP. CT. REV. 193, 210. But the privacy policy has not survived scrutiny. See Fisher v. United States, 425 U.S. 391, 399-401 (1976); Friendly, supra note 87, at 687-90.

In a forthcoming article I attempt to explain more fully why the privilege is an unsuitable vehicle for protecting privacy. Whether allowing a remedy to private plaintiffs stymied by the privilege would offend privacy concerns is doubtful in any event.

103. E.g., Lyons v. Johnson, 415 F.2d 540 (9th Cir. 1969) (dismissing suit), cert. denied, 397 U.S. 1027 (1970); Brown v. Ames, 446 F. Supp. 1176 (D. Minn. 1972) (same). 
missed, or whether less severe measures would occasionally be appropriate. ${ }^{104}$ But when defendants or their employees invoke, courts often neglect to devise an effective remedy for the plaintiffs. ${ }^{105}$ Some courts refuse to allow plaintiffs any remedy on the ground that doing so would tend to make the invoker's exercise of the privilege "costly."

This part of the Article examines the range of possible remedies for the plaintiff. ${ }^{107}$ It concludes that the most effective remedy is to ensure that when the defendant or his employees invoke during discovery, the plaintiff will be able to bring that fact to the attention of the jury, to argue whatever inferences follow from it, and, when necessary, to shift the burden of producing evidence of the defendant's conduct. A court alert to the obstructive potential of the privilege should also bar those who invoke during discovery from testifying at trial.

\section{A. Remedies to Reject}

Some of the remedies for plaintiffs that have been suggested in the past are less sound in concept and less effective in practice than others. Narrowing the current standards for an incriminating response so that the privilege can only be invoked when the invoker is likely to be prosecuted, or when his response is more incriminating as a matter of degree, merely replaces the problematic current approach with one that is wholly unworkable. Granting protective orders is not likely to induce invokers to respond, nor is it consistent with society's interest in effective law enforcement. Compelling responses on the ground that they are sure to be "derived" from past grants of use immunity distorts the use immunity concept and allows the court to usurp the prosecutor's authority to control immunity.

\section{Tinkering with Hoffman}

As discussed above, the current standards set forth in Hoffman and its progeny require the court to uphold an invocation of privilege as long as

104. A few courts have felt that dismissing the plaintiff's suit is too severe a sanction for invoking the privilege. E.g., Campbell v. Gerrans, 592 F.2d 1054 (9th Cir. 1979); Justice v. Laudermilch, 78 F.R.D. 201 (M.D. Pa. 1978). See generally Comment, supra note 2 (discussing sanctions against plaintiff for invoking privilege).

105. The sharp disparity in treatment accorded invoking plaintiffs and defendants has been criticized. See Wehling v. CBS, 608 F.2d 1084, 1089 n.10 (5th Cir. 1979); Kaminsky, supra note 2, at 149, 153-56.

106. E.g., Frierson v. McIntyre, 151 F. Supp. 5, 6-7 (D. Va. 1953); Mayo v. Ford, 184 A.2d 38, 40 (D.C. Mun. Ct. App. 1962).

107. Unless otherwise indicated, this discussion of remedies applies whether the invoker was the defendant or the defendant's employee, and regardless of the stage at which the invocation of privilege occurred. As indicated earlier, a corporate or partnership defendant will not usually be able to invoke successfully in its answers, replies to interrogatories, or requests for admissions. 
the invoker's response might supply a clue to investigators or a link in a chain of circumstantial evidence showing some criminal conduct. ${ }^{108}$ To overrule a privilege claim, the challenger must show that it is " 'perfectly clear, from a careful consideration of all the circumstances in the case, that the witness is mistaken, and that the answer[s] cannot possibly have such tendency to incriminate." 109 The invoker need not reveal his response, he may show the incriminatory potential through argument rather than evidence, and he receives the benefit of any doubt. This holds true even if the invoker has been prosecuted before and even if no practical danger of future prosecution exists. ${ }^{110}$

Judicial efforts to revise these standards are of two types. One approach would deny the privilege to an invoker in a civil case who could not show that his response would contribute to a realistic, rather than a theoretical, danger of prosecution. An alternative approach would require the invoker to demonstrate more clearly than current standards require that his response would materially aid the prosecutor's case should prosecution be commenced. Whether the revisions focus on the likelihood of prosecution or on the actual danger of the response, however, the underlying aim is to grant the privilege only to those who have demonstrated that they will seriously increase their criminal exposure by responding.

\section{a. Compelling A Response When Prosecution Is Unlikely}

The district court in In re Folding Carton Antitrust Litigation ${ }^{111}$ adopted the first approach. The case was a consolidated private civil suit in which several dozen plaintiffs alleged that a number of defendant corporations had fixed the wholesale and retail prices of folding cartons in violation of section 1 of the Sherman Act. Like so many private pricefixing cases, this one came in the wake of the federal prosecution of the defendants and their executives for the same price-fixing conspiracy. The criminal case was completed and most of the defendants had pleaded no contest by the time the plaintiffs in the civil case began deposing employees of the defendant corporation. Some of these deponents had been prosecuted by the Justice Department. Most had invoked the privilege and had received use immunity for testifying in the grand jury investigation that led to the earlier indictment. Nevertheless, these deponents invoked the privilege in response to nearly every question of the civil plaintiffs.

Had the district court adhered to Hoffman, it would have upheld these invokings: the court recognized the incriminating character of the re-

108. Hoffman v. United States, 341 U.S. 479, 486-87 (1951).

109. Id, at 488 (quoting Temple v. Commonwealth, 75 Va. 892 (1881)) (emphasis omitted).

110. See supra pp. 1066, 1071-80.

111. 465 F. Supp. 618 (N.D. Ill.), vacated, 609 F.2d 367 (7th Cir. 1979). 
sponses that would have been compelled but for the privilege. ${ }^{112}$ It also noted that the statute of limitations had not run on the crimes for which the responses might have provided evidence. ${ }^{113}$ Nor did double jeopardy or past grants of use immunity necessarily preclude future prosecution of these deponents. Glearly the theoretical possibility that the responses could be used in future prosecutions still existed.

The court nevertheless refused to uphold these invocations of privilege concluding that the threat of prosecution of these deponents was too remote. ${ }^{134}$ The court based this conclusion on several facts: the federal prosecution of the conspiracy had been completed, no state criminal investigation of the price-fixing in question was in progress, and any future prosecutor of the deponents given use immunity would face substantial difficulty in showing that his case did not use directly or indirectly any information derived from their immunized grand jury testimony. ${ }^{115}$

Although reversed on appeal, the district court's rejection of the rule that a mere possibility of prosecution allows one to invoke deserves serious consideration. First, the court's approach confronts the full implications of the "possibility" rule:

Strong policy considerations support the result reached here. Federal and state criminal statutes have an expansive and omnipresent sweep in modern society. There are a multitude of situations where potential criminal and civil liability overlap. Sustaining a civil witness's refusal to testify on fifth amendment grounds every time an answer might give rise to some theoretically possible future criminal prosecution, no matter how remote, would signal a virtual end to discovery in civil cases. Assertions of the fifth amendment which, as a practical matter, are frivolous should not be allowed to frustrate discovery in civil cases. ${ }^{116}$

Second, as discussed earlier, a deponent who does not face a realistic danger of prosecution is not subjected to the cruel trilemma of incrimination, perjury or contempt. ${ }^{17}$ Hence the primary policy for allowing use of the privilege in civil cases does not operate with force in such a case.

Nevertheless, the district court's approach creates as many difficulties as

112. 465 F. Supp. at 621-22.

113. Id. at 622 .

114. Id. at $622-23$.

115. Id.

116. Id. at 625. Other courts have suggested similar approaches. E.g., Priebe v. World Ventures, Inc., 407 F. Supp. 1244, 1246 (C.D. Cal. 1976) (dictum) (privilege cannot be invoked without demonstration of real and appreciable risk of self-incrimination); In re Duckett, 76 Cal. App. 3d 692, 143 Cal. Rptr. 199 (1978) (privilege is unavailable absent reasonable apprehension testimony could lead to criminal prosecution).

117. See supra p. 1086 \& note 100. 
it resolves. First, any future prosecutor of the invoker at the state or federal level will need to show that he made no use of the compelled response, ${ }^{118}$ a burden "heavy" in theory and often crushing in fact. ${ }^{11}$ The difficulty of meeting this burden is one reason the immunity statutes at the state and federal level permit only the executive branch to initiate grants of use immunity. ${ }^{120}$ Yet by compelling the invoking deponent to answer, the court in effect grants use immunity for the testimony without any clearance from the prosecution.

Second, a judge will rarely be able to hold with confidence that the possibility of future prosecution is negligible. This is particularly true when no criminal charges have been brought at the time of the invoking and the incriminating information is apparently not known to the government. The district court in In re Folding Carton held an unusually favorable vantage point for seeing that no future prosecution of the invokers was likely. The federal Antitrust Division had completed its misdemeanor criminal case charging a conspiracy to fix the prices of folding cartons that lasted until December 1974..$^{121}$ Some of the deponents had been defendants in that criminal case. Others had been granted use immunity for their testimony in the grand jury proceedings leading to that indictment. ${ }^{122}$ Those familiar with the practices of the Antitrust Division could safely predict that it would not begin another prosecution against those officials for their participation in a conspiracy to fix the price of folding cartons. Nor did the states with jurisdiction to prosecute seem likely to do so. ${ }^{123}$ State price-fixing prosecutions duplicating federal prosecutions have been rare. State prosecutors would face the same difficulty as federal prosecutors in overcoming the effects of the previous grants of immunity. ${ }^{124}$ Although state prosecutors had presumably known about the federal case for many months, none had shown an interest in proceeding.

118. Kastigar v. United States, 406 U.S. 441, $461-62$ (1972).

119. See United States v. Barker, 542 F.2d 479, 484 n.9 (8th Cir. 1976) (burden of proving no use may be "extraordinary"). The future prosecutor must demonstrate that all of the evidence he seeks to use has been derived from sources independent of the immunized testimony. See United States v. Seiffert, 501 F.2d 974, 982 (5th Cir. 1974). This includes showing the immunized testimony has not been used in cross-examination, New Jersey v. Portash, 440 U.S. 450 (1979), or for non-evidentiary goals, such as preparing trial strategy. United States v. McDaniel, 482 F.2d 305 (8th Cir. 1973).

The burden of proof imposed by the court may be substantial. See United States v. Henderson, 406 F. Supp. 417, 423 (D. Del. 1975) (assuming government must show beyond a reasonable doubt that evidence was derived solely from 'independent, legitimate' sources); United States v. Birrell, 269 F. Supp. 716, 725 n.13 (S.D.N.Y. 1967) (requiring clear and convincing proof); Strachan, Self-Incrimination, Immunity, and Watergate, 56 TEX. L. REV. 791, 830 (1978) (requirement of proof stronger than preponderance of evidence).

120. E.g., 18 U.S.C. $\$ 6003$ (1976) (requiring motion from U.S. Attorney for immunity order); NEB. REV. STAT. $\$ 29-2011.01$ (1979) (requiring motion from county attorney for immunity order).

121. 465 F. Supp. at 621-22.

122. Id. at 626 .

123. Id. at 622 .

124. Id. at 623 . 
But even in this case the district court could not be confident that the deponents would not be prosecuted for the past acts their responses might reveal. The deponents, especially those who had not received use immunity, might still have been prosecuted for fixing prices of products other than folding cartons. In fact, the invokers claimed grand jury investigations of price-fixing on paper cartons and milk cartons were in progress at the time. And historically the Antitrust Division has been willing to bring multiple prosecutions based on closely related conduct that amounts to participation in more than one price-fixing conspiracy. ${ }^{125}$ The court should at least have evaluated the chance that the grand jury investigations of possible price-fixing of other products would lead to prosecution of these deponents.

Even if the court could have been sure that no criminal antitrust charges would be brought, incriminating information provided by the deponents' responses might have triggered prosecution for other crimes. For instance, the federal authorities might have considered criminal charges if the information given by the deponents showed that some had committed perjury before the grand jury. Or the information might have provided evidence or investigatory clues for crimes wholly unrelated to price-fixing. Because a court must either uphold or overrule a privilege claim at a time when it may not know the invoker's full response or all the crimes for which the response may incriminate him, it can hardly predict with confidence whether all prosecutors able to do so will opt not to prosecute for these separate crimes. Attempting to assess how state and federal prosecutors and their successors will exercise their discretion to prosecute, and upholding or overruling an invoking based on that assessment, is as unseemly and speculative an endeavor for the courts as one could create.

\section{b. Altering the Standards for Finding Incriminating Potential}

The Seventh Gircuit Court of Appeals reversed the district court in a manner suggesting a second way of altering Hoffman. ${ }^{126}$ Although the court reiterated that a mere possibility of prosecution was a sufficient danger to trigger Fifth Amendment protection, it did not uphold the deponent's privilege claims outright. Instead, it remanded the case, instructing

125. Compare United States v. Hawaiian Conference of Tour Operators, No. 609 (D. Hawaii filed Oct. 5, 1975) (defendant indicted for fixing prices of Free Independent Tour packages to Hawaii) with United States v. Hawaiian Holidays Inc., No. 922 (D. Hawaii filed Oct. 2, 1976) (same defendant, after conviction on earlier charge indicted for fixing prices on Group Inclusive Tour packages to Hawaii). See also United States v. H.E. Koontz Creamery, 257 F. Supp. 295, 297-98 (D. Md. 1966) (defendant dairy owners, convicted of rigging bids for school milk contracts from 1959 to 1960 , were subsequently indicted for fixing resale and wholesale milk prices in same town from 1956 to 1960).

126. In re Folding Carton Antitrust Litig. (Appeal of Brown), 609 F.2d 867 (7th Cir. 1979). 
the district court to demand a better showing from the deponents that their responses would be incriminating. ${ }^{127}$

The Seventh Circuit's approach is only one of several ways that a court might ease Hoffman's standards by focusing on the incriminating nature of the response rather than on the likelihood of prosecution. A court could require the invoker to indicate what his response would be, or refuse to grant the invoker the benefit of all doubts. Again, it might narrow the notion of an incriminating response to include only responses that on their face show criminal conduct. This would exclude responses that only provide clues or circumstantial evidence. Finally, a court might protect only responses likely to play a substantial role in a later prosecution of the invoker; responses generating evidence likely to be cumulative or to establish matters not in serious dispute could be compelled.

These reformulations of Hoffman present serious difficulties, however. First, despite recent ambiguous decisions ${ }^{128}$ the long-term trend of Fifth Amendment jurisprudence that culminated in the present standards reflects an evolving awareness of the need to consider incriminating a wide variety of responses. Until roughly the turn of the century, some courts upheld the privilege only when the response would admit, if not an entire crime, then at least an element of a crime. ${ }^{229}$ Under this standard, however, a careful questioner, by compelling responses that would provide circumstantial evidence or clues, could force a witness to prove a case against himself and thwart the policies behind the privilege. In Ward v. State for

127. Id. at 873 .

128. A number of recent Supreme Court cases support to some extent these reformulations of the Hoffman standard. The notion that responses on their face must provide incriminatory evidence, and not merely circumstantial evidence or investigatory leads, gains support from Zicarelli v. New Jersey State Comm'n of Investigation, 406 U.S. 472 (1972). In that case the Court held that an immunized witness's response admitting his Cosa Nostra responsibilities in certain geographic areas in the United States would not incriminate him under foreign law. Id. at 478-81. The Court did not even consider the obvious possibility that his answers would provide circumstantial evidence or investigatory leads helpful in a foreign prosecution.

The notion that the response must provide incriminating evidence likely to be of practical value in a later prosecution gains support from Fisher v. United States, 425 U.S. 391 (1976). In Fisher, the Court observed that the production of documents in response to a subpoena, while impliedly admitting the possession of the documents, merely provided cumulative evidence of their possession. Thus, production could not be avoided by claiming the privilege. Id. at 396-401. The clear suggestion was that lower courts, in assessing claims of privilege, should assess the practical value of the response to prosecutors. See also Marchetti v. United States, 390 U.S. 39, 53 (1968) ("The central standard for the privilege's application has been whether the claimant is confronted by substantial and 'real,' and not merely trifling or imaginary, hazards of incrimination."); United States v. Apfelbaum, 445 U.S. 115,128 (1980) (quoting $M$ archetti with approval). These statements may presage a major restriction of Hoffman's standard for an incriminating response.

129. E.g., In re Briggs, 135 N.C. 118, 145, 47 S.E. 403, 411 (1904); State v. Duffy, 15 Iowa 425, 426 (1863).

Counselman v. Hitchcock, 142 U.S. 547 (1892), made clear that in the federal system an answer need not admit an element of a crime to be incriminating. See also United States v. St. Pierre, 132 F.2d 837, 838 (2d Cir. 1942) (discussing Counselman). 
example, a grand jury witness was compelled to answer the question: "Tell who bet at the game of Faro, not naming yourself." ability to answer combined with the circumstance that the illegal games were held in secret would provide circumstantial evidence that the witness attended and knew the game of Faro was being played. The answer would also provide damaging clues since the bettors named could be contacted and forced to incriminate the witness. Surely the extension of the privilege to protect circumstantial evidence and clues represents an advance needed to keep the privilege meaningful. ${ }^{131}$

But if it is illogical to uphold the privilege only when the response on its face would show criminal conduct, it is unworkable to tie the availability of the privilege to an assessment of how incriminating, as a matter of degree, the response would be. We have seen that under Hoffman the court must often decide whether the response may be incriminating at a time when it lacks information to do more than speculate. Yet under a reformulation limiting protection to a response that is significantly incriminating, even more is expected of the court. A still more demanding standard that would uphold the privilege only when the incriminating evidence is likely to provide practical assistance to the prosecution would require the court to anticipate the strengths and weaknesses of the future prosecutor's case. Consider the dilemma of a judge in a routine divorce case when a deponent-defendant asked about his assets invokes on the ground that his response might suggest he had received income not reported on his tax return. The invoker, while asserting his innocence of a tax offense, may claim the response would help a future prosecutor mount a misguided case against him. The judge must then attempt to anticipate the strengths and weaknesses of that misguided case and the role this response would play. And because the availability of the privilege must be assessed question by question at the civil deposition, ${ }^{132}$ each new question and invocation of the privilege will require new decisions. ${ }^{133}$ At least the Hoffman standard led to a predictable result-the invoker always won.

Finally, none of the revisions constitutes an effective solution for the plaintiff when the defendant or his employees have been involved in a crime. The greater their involvement, the easier it will be for them to show that their answers would incriminate under any test. If pressed for a better showing that their responses will incriminate, they will oblige. The plaintiff still confronts the anomaly that the greater the criminal liability of the defense, the more easily it may block his discovery.

130. 2 Mo. 120,122 (1829).

131. See Ratner, supra note 43 , at $480-91$.

132. See supra note 52.

133. See Gulf Oil Corp. v. The Tug Kate Malloy, 291 F. Supp. 816, 818 (E.D. La. 1968). 


\section{Protective Orders}

A few commentators have suggested that the astute use of protective orders offers the best solution when defendants or their employees invoke during a civil case. ${ }^{134} \mathrm{~A}$ protective order would apply most often to depositions, but might apply to any response to discovery that could have been avoided by the privilege. The order would keep these responses away from the government by forbidding their disclosure to anyone except persons designated in the order, usually the plaintiff and his attorney. With such an order, the notion seems to be, the defendants and their employees will be willing to waive the privilege and respond to the discovery requests.

One obvious factor prevents this approach from opening up discovery. The approach relies entirely on the potential invokers' willingness to waive the privilege in return for a protective order, for the order itself does not allow a court to compel the invoker to respond. Kastigar $v$. United States established that before a witness who claims the privilege can be compelled to respond, he must be provided with an order that displaces the need for the privilege entirely. ${ }^{135} \mathrm{~A}$ use immunity order satisfies Kastigar only because it assures the invoker that his response will not be used directly or indirectly to prosecute him. Hence, his response will not under any circumstances increase his chance of being convicted in a criminal case. A protective order in a civil case carries no similar assurance. Such an order allows the response, or at least information derived from the response, to spill out at trial, appeal, or some other hearing, where it could be discovered and later used by prosecutors. No protective order could provide the absolute protection that Kastigar requires against direct or indirect use by prosecutors. The court can hardly hold all proceedings-including the trial and the appeal-in secret, seal all records indefnitely, and prevent all participants from supplying information to the government.

If a protective order barred the plaintiff from using the response in any hearing to which the government might obtain access, it would force the plaintiff to refrain from offering any evidence that might be said to be derived directly or indirectly from the response. It would put plaintiffs preparing for trial in an absurd position.

In any event, no matter how sweeping the protective order, the danger exists that the other parties or their counsel may violate it and convey to the government the information the witness has provided. If the govern-

134. See Donnici, supra note 2, at 16; Note, Constitutional Law, supra note 2, at 248; Note, Resolving Tensions Between Constitutional Rights: Use Immunity in Concurrent or Related Proceedings, 76 CoLUM. L. REV. 674 (1976).

135. 406 U.S. $441,459-61$ (1972). 
ment was allowed to use this information, then the protective order would not have displaced the need for the privilege. But if the government was not allowed to use this information, then as a practical matter the person leaking the information may have crippled the government's capacity to prosecute. ${ }^{136}$

Federal antitrust prosecutors will probably be able to obtain any incriminating responses given under protective orders in private civil cases without even waiting for a hearing or a leak. In United States v. GAF Corporation, ${ }^{137}$ the Second Circuit, citing the Antitrust Civil Process Act of $1976,{ }^{138}$ enforced a civil investigative demand (CID) from the Justice Department for discovery responses obtained by plaintiffs in a civil antitrust suit, despite a protective order barring the parties from allowing access to the responses. ${ }^{139}$ According to the Second Circuit, the courts have the discretion to refuse enforcement of CID's in some instances. ${ }^{140}$ But as long as the invoker in a civil suit faces the mere possibility that his response will reach the government and be used directly or indirectly in a criminal case against him, the Kastigar requirements will not be met and a response cannot be compelled.

The court's inability to compel an incriminatory response would not necessarily negate the value of the protective order if in fact the order persuaded potential invokers in a civil suit to waive the privilege and respond. From the perspective of the potential invoker, however, the relative costs and benefits of invoking or waiving the privilege are not significantly altered by a protective order.

Presumably the major asserted benefit of the protective order is that it reduces the danger that waiving and responding in the civil suit will lead to criminal prosecution. The order lessens the chance that an incriminating discovery response will be brought to the attention of the government. ${ }^{141}$ With a protective order there is less danger, for example, that the

136. The leaking of the compelled response would require future prosecutors to show that they made no use of the response. For an assessment of the difficulty of meeting this burden, see supra p. 1091 \& notes $118-20$.

137. 596 F.2d 10, 16 (2d Cir. 1979).

138. 15 U.S.C.A. $\S 1312$ (West 1982).

139. See Martindell v. ITT, 594 F.2d 291, 297 n.8 (2d Cir. 1979) (granting of government's request to modify protective order in private case lies within trial court's discretion).

140. 596 F.2d at 16 .

141. Even when the government's attention has been drawn to the conduct of the defendants and their employees, the protective order slightly reduces the extent to which waiving and responding in the civil suit helps the government build its criminal case. Because of the protective order, the wouldbe criminal targets who provided the responses would have a stronger argument for resisting government subpoenas or CIDs aimed at obtaining the responses from the plaintiff. As in Martindell v. ITT, 594 F.2d 291 (2d Cir. 1979), they will argue that the protective order, which was clearly designed to suppress the response from the government, gave them a legitimate expectation that it would be enforced and that they only waived the privilege and responded in reliance on that expectation. The prospect that future deponents will always invoke unless the protective orders are consist- 
plaintiff's attorney will send incriminating deposition answers to the government with an explanation of their significance. In the same way, the protective order, by keeping the responses from the attention of other potential plaintiffs, should limit the increase in civil exposure that may result from waiving and responding. The order should also reduce the possible collateral consequences of incriminating responses, such as damage to the potential invoker's reputation.

On closer examination, however, these purported benefits lose much of their value. ${ }^{142}$ When civil liability arises from incriminatory acts, much of the evidence showing the illegal acts should eventually surface at trial, even if effectively suppressed before then. The evidence revealed at trial is as likely to flag the attention of prosecutors and other potential plaintiffs and to harm the deponent's reputation as the original discovery responses.

Consequently, a protective order merely ensures that the circulation of the incriminating responses will be limited temporarily. ${ }^{143}$ It is therefore likely to induce a waiver and response only from those seeking to suppress their response temporarily. But temporary suppression should not appeal to many, for the damage to reputation and the other collateral consequences from distributing the response remain even if the temporary suppression reduces criminal exposure.

No doubt instances will also arise when the incriminating responses sought in a deposition or other discovery device do not relate to important matters in the civil action. Then the witness may realize that the trial and other hearings will bypass the responses altogether, with the result that the protective order will limit the circulation of the incriminatory responses permanently. The same result often occurs when the case settles before trial. Here again the person whose primary concern centers on limiting the circulation of his incriminatory responses may be induced by the

ently enforced also supports their claim. Moreover, the government can obtain the information by giving them immunity. All these factors may persuade the court to refuse enforcement of the government subpoenas or CIDs.

But despite any such "reliance" on the protective order, the Antitrust Procedural Improvements Act of 1980, Pub. L. No. 96-349, 94 Stat. 1154 (1980) (to be codified in scattered sections of 15 U.S.C.), may be construed to require the trial court to enforce government CID requests for depositions and other responses to discovery. The Act states in part: "[A]n express demand for any product of discovery supersedes any inconsistent order ... preventing or restraining disclosure of such product of discovery to any person. . . " 15 U.S.C.A. $\S 1312$ (c)(2) (West 1982) See also infra notes 145-46 (discussing Act).

Should the government attempt to obtain the discovery response by subpoena, Martindell might still allow the trial court the discretion to refuse enforcement. See 594 F.2d at 296 n.6 (declining to decide that issue).

142. Defendants and their employees will still desire protective orders, which are, after all, costless to them and which may suppress their responses permanently if the case settles before trial.

143. Indeed, protective orders are generally suggested as a solution only when criminal proceedings are pending at the time of civil discovery. E.g., General Dynamics Corp. v. Selb Mfg. Co., 481 F.2d 1204, 1215 (8th Cir. 1973); Note, Federal Courts-Discovery, 66 MICH L. REv. 738, 742-43 (1968). 
protective order to waive.

The primary point, however, is that the strategic advantages of invoking for defendants and their employees-the ability to retard the plaintiff's discovery and to contain the disruptive impact of the plaintiff's action-dictate against waiving even when concerns about criminal and civil exposure and collateral consequences do not. Unless those advantages are offset by affording plaintiffs some remedy when the privilege is invoked, those able to invoke are not likely to waive.

Judges who recognize that granting a protective order will probably not induce defendants and their employees to waive may still grant the order for various reasons. They may feel the order does no harm and tends, however slightly, to induce waiver in a few instances. More commonly, they may use the protective order as a prelude to other remedies, and if the deponents persist in invoking, only then impose the remedies recommended here, such as barring the invokers from testifying and bringing the invoking to the jury's attention. Their view, perhaps, is that the protective order bolsters the case for remedies by reducing further the chance that the invoker's response would in fact be used to prosecute him.

But this approach overlooks the public interests undermined by any protective order that suppresses information about crimes from the government. Judicial independence from the executive branch does not require courts in civil cases to remain indifferent about whether the government learns of past crimes or gathers sufficient evidence to establish them. On the contrary, the Supreme Court has recently emphasized that it is the obligation of everyone to report crimes that come to his attention. ${ }^{144}$ The hardship and oppression from civil discovery, which under the discovery rules warrant a protective order, must not include the hardship resulting from revealing past crimes or even past circumstances that incorrectly suggest crimes.

Protective orders that may conceal information from the government should especially be avoided in private antitrust cases. In passing the Hart-Scott-Rodino Antitrust Improvements Act of 1976, ${ }^{145}$ Congress

144. Roberts v. United States, 445 U.S. 552, 557 (1980) ("Concealment of crime has been condemned throughout our history.") See also Jenkins v. Anderson, 447 U.S. 231,243 n.5 (1980) (Stevens, J., concurring) ("There is, of course, no reason why we [the Court] should encourage the citizen to conceal criminal activity of which he has knowledge.")

145. Pub. L. No. 94-435, 90 Stat. 1383 (codified at scattered sections of 15, 18, and 28 U.S.C. (1976)). Within four years of passing the Hart-Scott-Rodino Act Congress again sought to improve antitrust enforcement through the Antitrust Procedural Improvements Act of 1980, Pub. L. No. 96349, 94 Stat. 1154 (to be codified in scattered sections of 15 U.S.C.). This Act responded to United States v. GAF Corp., 596 F.2d 10, 15 (2d Cir. 1979), and confirmed the government's authority to obtain from private plaintiffs the responses and information they had gathered through their civil discovery. 15 U.S.C. $\$ 1311$ (1976). The Act expressly approved the Justice Department's use of the fruits of a private plaintiff's discovery effort and reflected the conviction that the reasons for granting protective orders pale in comparison to the interest in more effective and less wasteful antitrust en- 
reemphasized the national interest in bringing antitrust violations to the government's attention. ${ }^{146}$ The Act improved in several ways the Justice Department's capacity to spot violations. ${ }^{147}$ Yet protective orders in private antitrust cases pose precisely the danger that the violations revealed in discovery but suppressed by the order will never be spotted by the government or will be spotted too late for government action to be feasible. Granting such a protective order, at least in the absence of any reason other than the desires of the private parties, flies in the face of this congressional action.

Even when the government is likely to spot the violation in time to investigate, the trial court should refuse to approve a protective order directed against the government. Granting the order invites the dilemma faced by the court in Martindell v. ITT. ${ }^{48}$ There the government attempted to obtain the discovery response provided to the private plaintiff in the civil case. To reject its efforts would have been to interrupt, perhaps to doom, proper law enforcement efforts. On the other hand, those who provided the discovery response could claim they did so, rather than invoke, in reliance on the protective order. It is no answer to this situation to say, as the Second Circuit did, ${ }^{149}$ that the government may always obtain this information itself by giving immunity. To give immunity to those with the desired information is often to nullify any hope of prosecution. Should the trial court respond that without the protective order no waiver would have occurred and no information would have surfaced in the first place, the reply must be that the better practice is to create remedies for the plaintiff when the defendants or their employees invoke rather than to grant a protective order, obtain a waiver, and then help the defendants keep the door shut on the government. ${ }^{150}$

forcement. See H.R. REP. NO. 870, 94th Cong., 2d Sess., reprinted in 1980 U.S. CODE CONG. \& AD. NEwS 2716, 2723.

146. See generally S. REP. No. 803, 94th Cong, 2d Sess. pt. 1, at 1 (1976); Note, Government Use of the Civil Investigative Demand to Obtain Materials Discovered in Private Antitrust Litigation, 79 COLUM. L. REV. 804, 807-10 (1979) (discussing legislative history).

147. The Act authorized the Department to serve a Civil Investigative Demand upon any natural person or corporation that may have information pertaining to an antitrust violation, supplementing an earlier Act that allowed a CID to be served only upon corporations under investigation. Compare Pub. L. No. 94-435, § 102, 90 Stat. 1383, 1384 (1976) with Pub. L. No. 87-664, § 3(a), 76 Stat. 548, 548 (1962). The current statute is codified at 15 U.S.C. $\$ 1312($ a) (1976). The Act also authorized the service of CIDs to investigate activities that may result in antitrust violations; under the earlier Act, CIDs could only be used to probe past or ongoing violations. Compare Pub. L. No. 94-435, § 101 (2), 90 Stat. 1383, 1383 (1976) with Pub. L. No. 87-664, § 2(c), 76 Stat. 548, 548 (1962). The current statute is codified at 15 U.S.C. $\S 1311$ (c) (1976). The Act further allowed use of CIDs to demand interrogatories and depositions, not merely documents. Compare Pub. L. No. 94-435, $\S 102$, 90 Stat. 1383, 1384 (1976) with Pub. L. No. 87-664, § 3(a), 76 Stat. 548, 548 (1962). The current statute is codified at 15 U.S.C. $\S 1312$ (a) (1976).

148. 594 F.2d 291 (2d Cir. 1979).

149. Id. at 296.

150. Plainly, no due process concerns are raised if the government takes advantage of self-incrimi- 


\section{Judicial Grants of Use Immunity}

We have seen that granting the invoker a protective order does not so displace the need for the privilege that a response can be compelled. If the court does erroneously compel the invoker to respond, remedial principles require that the invoker receive use immunity for his response. ${ }^{151}$ Thus, an erroneous order to respond may provide the plaintiff his discovery and the invoker his immunity.

This result suggests a possible solution for cases in which civil discovery is blocked by the privilege. That solution calls for the judge to override the privilege when it is invoked in the civil case and to compel a response. ${ }^{152}$ In short, the judge is to grant the invoker use immunity just as the government might choose to do if it were the plaintiff. Although some invokers will defy the compulsion order and subject themselves to contempt proceedings, at least some should comply. ${ }^{153}$

The flaw in this solution is that the statutory power to grant immunity is generally limited, for cogent policy reasons, to the executive branch. ${ }^{154}$ Under these immunity statutes, the executive branch must request all use

natory information disclosed in civil discovery by one who could have invoked the privilege. The law enforcement personnel responsible for the criminal prosecution have not coerced the information in any way nor engaged in untoward practices. Nor has the plaintiff employed any improper or unfair methods to obtain the incriminatory information, at least when that information is relevant to liability in the civil case. Cr. Garner v. United States, 424 U.S. 648 (1976) (information on tax return given by one who could have invoked is admissible in criminal prosecution).

151. See Maness v. Meyers, 419 U.S. 449, 462 (1975) (dictum); cf. United States v. Blue, 384 U.S. 251,255 (1966) (evidence obtained by government in violation of privilege may not be used in subsequent prosecution).

152. See Daly v. Superior Court, 19 Gal. 3d 132, 560 P. 2d 1193, 137 Cal. Rptr. 14 (1977); Note, Resolving Tensions, supra note 134, at 678-87; Note, Constitutional Law, supra note 2, at 248. If immunity is to be granted in a civil suit not involving the government, the court must act on its own-the federal and state governments, not being parties, are not likely to be willing to intervene in order to grant immunity. The cost and difficulty of investigating whether the invoker is a possible target of future prosecutions are likely to deter such intervention.

153. For a discussion of the procedural options available to an invoker wishing to challenge a compulsion order, see Minnesota State Bar Ass'n v. Divorce Assistance Ass'n, 311 Minn. 276, 248 N.W.2d 733 (1976).

154. See, e.g., United States v. D'Apice, 664 F.2d 75, 77-78 (5th Cir. 1981); United States v. L'Hoste, 640 F.2d 693, 695 (5th Cir. 1981); United States v. Dunham Concrete Prods., 475 F.2d 1241, 1243-44 (5th Cir. 1972), cert. denied, 414 U.S. 832 (1973); 18 U.S.C. $\S \S 6001-6005$ (1976).

Despite pronouncements that the government controls use immunity, courts have granted use immunity without formal orders from the government in several situations. At proceedings for accepting pleas, for example, courts must grant defendants use immunity for their responses. FED. R. CRIM. P. 11(e)6. Courts have also given use immunity for statements made in presentence reports, sentencing proceedings, and other proceedings. E.g., United States v. Inmon, 568 F.2d 326, 332-33 (3rd Cir. 1977) (use immunity accorded to testimony in pretrial double jeopardy hearing). And in Simmons v. United States, 390 U.S. 377, 389-94 (1968), the Supreme Court held that the admission of testimony given in a pretrial motion to suppress evidence was reversible error.

Some courts have given use immunity to compel witnesses to testify for the defense in criminal trials. E.g., Virgin Islands v. Smith, 615 F.2d 964 (3d Cir. 1980). The court's authority to grant this immunity is a matter of dispute. See, e.g., Note, The Sixth Amendment Right to Have Use Immunity Granted to Defense Witnesses, 91 HARV. L. REV. 1266, 1268 (1978). 
immunity orders. ${ }^{155}$ The executive's control over use immunity follows naturally from its control over the decision to prosecute. While in theory granting use immunity leaves the government free to prosecute the invoker as long as it does not use his immunized testimony, in practice later prosecution is virtually foreclosed because the government's burden of proving it has not used the testimony is prohibitive. ${ }^{156}$ The government's chance of showing no use becomes even more remote when the judge in a private civil case grants use immunity without notice to the government. Then the government lacks even the opportunity to put under seal the evidence it has already gathered, a step commonly taken when the government hopes to show no use of forthcoming immunized testimony. ${ }^{157}$

Since granting use immunity so jeopardizes a future prosecution, Congress felt the discretionary judgment whether to exchange immunity for testimony ought to be left exclusively to the executive branch, rather than to the branch most insulated from popular control. ${ }^{158}$ As the Seventh Circuit noted:

The decision whether to confer immunity ... is the product of the balancing of the public need for the particular testimony or documentary information in question against the social cost of granting immunity and thereby precluding the possibility of criminally prosecuting an individual who has violated the criminal law. Therefore the relative importance of particular testimony to federal law enforcement interests is a judgmental rather than a legal determination, one remaining wholly within the competence of appropriate executive officials .... ${ }^{159}$

155. The federal district court must issue the order. See 18 U.S.C. $\S \S 6002-6003$ (1976). But the court's sole function is to ascertain whether the Justice Department has complied with the statute; it does not review the merits of the Justice Department's decision. See In re Kilgo, 484 F.2d 1215, 1219 (4th Cir. 1973); H.R. REP. No. 1549, 91st Cong., 2d Sess. 43, reprinted in 1970 U.S. CODE CONG. \& AD. NEwS 4007, 4018; H.R. REP. No. 1188, 91st Cong., 2d Sess. 13 (1970).

Congressional committees are also authorized to grant use immunity to their witnesses provided special procedures are followed. See 18 U.S.C. $\$ 6005$ (1976). These procedures are designed to insure that the Justice Department is alerted to the immunity request and is able to assess the effect of granting immunity on current and future prosecutions.

156. See Bauer, Reflections on the Role of Statutory Immunity in the Criminal Justice System, 67 J. CRIM. L. \& CRIMINOLOGY 143 (1976); Strachan, supra note 119, at 822; The Supreme Court, 1971 Term, 86 HARV L. REV. 50, 186-89 (1972); Note, The Unconstitutionality of Use Immunity: Half a Loaf is Not Enough, 46 S. CAL. L. REV. 202, 209 (1972).

Deciding whether the government has used the immunized testimony may require a post-trial hearing if only because of the possibility that the prosecutors will use the testimony in cross-examining defense witnesses or the invoker himself. New Jersey v. Portash, 440 U.S. 450 (1979) (use of immunized testimony in cross-examination is forbidden).

157. See Attorney General's Guidelines Relating To Use of Statutory Provisions To Compel Testimony or Production of Testimony $\S 7$ (Jan. 14, 1977).

158. See H.R. REP. No. 1549, supra note 155, at 43, 1970 U.S. CODE CoNG. \& AD. NEWS at 4018; H.R. REP. No. 1188, supra note 155, at 13.

159. In re Daley, 549 F.2d 469, $478-79$ (7th Cir. 1977). 
The judiciary also lacks the records needed for determining whether the public interest calls for prosecuting the invoker. At the federal level, for example, the Criminal Division of the Justice Department maintains extensive records and a search procedure for this very purpose. When future prosecution may be warranted, but other interests support granting immunity, the executive can also better evaluate whether the option to prosecute can be kept open despite a grant of immunity by careful questioning and other precautions. ${ }^{160}$

One might think that if a compulsion order is combined with a protective order, the government's burden of proving that it has not used the response will be manageable. But this approach suffers from all the shortcomings of protective orders decribed earlier. Moreover, the government will still face the burden of proving no use if the response or information derived from the response spills out at trial and comes to its attention. Furthermore, the plaintiff and any other persons privy to the response will then possess the power virtually to veto later prosecution of the invoker by leaking the response to the government. For once the information is released to the correct law enforcement officers, the government again faces the prohibitive burden of showing no use. Providing such power to private litigants, not all of whom are the invoker's adversaries even in the civil case, invites abuse and extortion.

While the immunity solution opens up plaintiff's discovery, it does so at the cost of foreclosing the government's opportunity for later prosecution. Assuming trial courts may grant use immunity in private civil cases, they should not so encroach on a domain traditionally reserved for prosecutors without legislative direction to do so.

\section{The Prospective Taint Fantasy}

Courts wishing to compel invokers to respond but unwilling, for the reasons given above, to grant them use immunity outright may claim that a previous grant of use immunity by the government in another proceeding will prevent the government from using the invoker's forthcoming responses against him. ${ }^{161}$ The previous grant of use immunity may have

160. Plainly the court in the private civil case is not in a position to know whether the invoker may have committed unrelated crimes or to alert those investigating unrelated crimes about the need for precautions. Nor is the plaintiff in the civil case likely to be able or inclined to tailor his questioning so as to preserve the option to prosecute for unrelated crimes.

161. Compare In re Corrugated Container Antitrust Litig. (Appeal of Fleischacker), 644 F.2d 70 (2d Cir. 1981) (compelling response based on previous grant of immunity) and Appeal of Starkey, 600 F.2d 1043 (8th Cir. 1979) (same) with In re Corrugated Container Antitrust Litig. (John W. Culy), No. 80-1443 (D.C. Cir. Aug. 28, 1981) (refusing to compel response based on past grant of immunity) and In re Corrugated Container Antitrust Litig. (Appeal of Franey), 620 F.2d 1086 (5th Cir. 1980) (same). The Supreme Court has granted certiorari in one such case. In re Corrugated Container Antitrust Litig. (Appeal of Conboy), 655 F.2d 748 (7th Cir.) (compelling testimony), rev'd 
been given in a grand jury or legislative investigation, a criminal trial or a government civil case. Because a use immunity order in one of these proceedings does not by its terms apply to testimony in a later proceeding, such as a private civil case, ${ }^{162}$ courts rationalize this approach by asserting that when the plaintiff uses the invoker's prior immunized testimony as the source of his questions, the responses will necessarily be derived from that testimony. Therefore, the responses would be tainted with the immunized testimony and could not be used in a prosecution of the invoker. With the invoker safely protected against prosecutorial use of his response, the response can be compelled. Because the court must decide that all possible answers to the plaintiff's questions will be tainted with the invoker's earlier testimony before it knows what those answers will be, one might say the court is granting use immunity based on a prospective taint.

The prospective taint approach will only assist a private plaintiff under limited circumstances. The invokers must have been immunized previously and must then have testified about conduct sufficiently related to the plaintiff's action to be discoverable. In addition, the invoker's immunized testimony must have been revealed to the plaintiff. Hence, the approach will be unavailable to plaintiffs not proceeding in the wake of a government investigation or unable to see the immunized testimony because of protective orders or concerns about grand jury secrecy. ${ }^{163}$ Ironically, the relatively few plaintiffs aided by the prospective taint approach need aid the least, for they have at least seen the immunized testimony and may be able to admit it in evidence despite the later assertions of privilege. ${ }^{164}$

The impulse behind the protective taint approach is understandable. The courts realize that the government's earlier decision to immunize the invoker greatly reduces the chance that he will be prosecuted, even though the possibility of prosecution remains. And the courts may believe that the testimony in the civil case will merely repeat the earlier testimony.

on reh'g, 661 F.2d 1145 (1981), cert. granted, 102 S. Ct. 998 (1982).

162. Cr. United States v. Kuehn, 562 F.2d 427, 430, 432 (7th Gir. 1977) (immunity does not apply to later separate criminal proceedings); United States v. First W. State Bank, 491 F.2d 780, 786 (8th Cir.) (same), cert. denied, 419 U.S. 825 (1974).

163. See Douglas Oil Co. v. Petrol Stops Northwest, 441 U.S. 211 (1979) (barring disclosure of grand jury testimony to civil litigant); United States v. Proctor \& Gamble Co., 356 U.S. 677, 681-84 (1958) (same).

164. Plaintiffs who have seen the immunized testimony of one who invokes during discovery and who does not testify at trial will face severe difficulties in getting the testimony admitted in their action, especially if no cross-examination was possible. Nevertheless, in the federal courts they can argue that the testimony given by a defendant or its employees constitutes party admissions under FED. R. EVID. 801(d)(2)(D). Or they can argue that the testimony falls within the "trustworthiness" exception of FED. R. Evid. 804(b)(5). See United States v. Carlson, 547 F.2d 1346, 1353-55 (8th Cir. 1976) (holding immunized grand jury testimony within "trustworthiness exception"), cert. denied, 431 U.S. 914 (1977). Even if the testimony is not admissible, it may furnish the plaintiff with clues. 
But the approach suffers from at least two critical shortcomings: its basic premise is suspect, and it inevitably leads to a proliferation of immunized testimony that encroaches upon the government's control of the scope of immunity and its ability to prosecute. The approach posits that the invoker's response to questions at the civil deposition must necessarily be derived from and hence tainted with the responses he gave during his immunized testimony whenever the questioner in the civil case has seen the immunized testimony. ${ }^{165}$ But while the government will face difficulty should it later attempt to prove the absence of taint in this situation, taint is not assured. That the plaintiff-questioner has seen the immunized testimony does not mean he has used the invoker's responses directly or indirectly in conducting the civil deposition. Often the questions to be asked in the deposition will be suggested rather obviously by the claims in the civil case. For instance, the mere suspicion of price-fixing, which may have arisen long before the immunized testimony occurred, will suggest a catalogue of questions to an antitrust litigator. The deposition questions may also have arisen from evidence discovered independently in the civil case or in the earlier criminal case. The plaintiff-questioner may have prepared his questions before he saw the immunized testimony or, having concluded that the immunized testimony provided no help, he may have discarded it and prepared his questions independently. That the questions in the civil case resemble or even duplicate the questions asked during the immunized testimony does not by any means establish that the testimony has been used. And surely the court should not accept uncritically the plaintiff's self-serving representations that his questions will be derived from the immunized testimony.

Even if the plaintiff uses, rather than merely duplicates, the questions asked by the government during the immunized testimony, he will not necessarily use the invoker's immunized responses. The government may have prepared all the questions it asked during the immunized testimony before hearing the responses. To use the government's questions is not to use the invoker's responses unless those responses assisted the government in framing its questions. And the immunity statutes only prevent use of the invoker's immunized responses, not use of the government's questions.

The difficulty of assuming taint becomes most evident when one remembers that the invoker's responses may differ from those given during the immunized testimony. Assume that for six months the invoker had

165. More sweeping theories for assuring taint have already been rejected. For instance, in United States v. Kuehn, 562 F.2d 427, 432 (7th Gir. 1977), the court refused to find that statements to the press immediately following immunized testimony before a grand jury were derived from that testimony. Taint could not be assumed simply because the news conference would not have occurred absent the immunized testimony. 
been an excutive of a company that the plaintiff long suspected of pricefixing. During the grand jury investigation the invoker received immunity, and, when asked if he had discussed prices with the executive of his company's primary competitor, claimed lack of memory. Yet in the later private civil case, the invoker, after being compelled to testify, may in response to the same obvious question admit many incriminatory discussions. In this commonplace example it is far from clear that the new responses in the civil case would necessarily be derived from the earlier immunized testimony. In general, the possibility of new responses undermines the assumption that all responses will be derived.

Another example of the same point arises when the invoker claims his truthful testimony at the civil deposition may tend to incriminate him for perjury committed during the previous immunized testimony. At least one circuit court has found that invocations of privilege based on the fear of incriminating one's self for perjury committed during prior testimony must be sustained. ${ }^{166}$ Nothing prevents a prosecution for the earlier perjury, and a truthful response to certain questions at the deposition in the civil case may indeed provide either evidence or clues of that earlier perjury. The plaintiff seeking to compel the testimony will answer this claim by asserting that the truthful testimony in the civil case cannot be used to show perjury because it also is "derived" from the immunized testimony, having been triggered by questions from a plaintiff who had seen the immunized testimony. This answer brings the key question underlying the premise of the prospective taint approach into relief: is it sensible to assume that forthcoming testimony will necessarily be derived from earlier, possibly contradictory testimony just because the questioner has seen the earlier testimony and is asking similar questions? ${ }^{167}$

166. United States v. Housand, 550 F.2d 818 (2d Cir. 1977); see also United States v. Partin, 552 F.2d 621, 632 (5th Cir.) (by implication), cert. denied, 434 U.S. 903 (1977).

167. The danger of new responses has been overlooked by some courts who believe that the harm to the government can be avoided by limiting the questions plaintiff may ask at the deposition. Accordingly, one court limited a plaintiff to "questions which [were] within the same time, geographical and substantive framework as the [immunized] grand jury testimony." Appeal of Starkey, 600 F.2d 1043, 1048 (8th Cir. 1979). Another, believing this standard not sufficiently "circumscribed," limited plaintiff to questions that "concerned specific subjects that actually were touched upon by questions .. . [asked during] the immunized testimony." In re Corrugated Container Antitrust Litig. (Appeal of Fleischacker), 644 F.2d 70, 79 (2d Cir. 1981). Apparently these courts assumed-though their basis for doing so is not explained-that if the questions at the deposition are sufficiently linked to those asked earlier, all responsive answers will be so similar to earlier answers that they will necessarily be tainted and will not increase the government's burden of showing the absence of taint.

Even if the proliferation of immunized testimony could be prevented by overseeing the questions the plaintiff may ask, devising and applying proper standards for permissible questions creates a significant burden for the court. As soon as the plaintiff departs from the script of the immunized testimony, and he would gain little by adhering to that script throughout, the issue arises whether the question and the possible responsive answers are sufficiently linked to the earlier immunized testimony. With each question the court must consider not only whether the question and all responsive answers must necessarily be tainted, but also whether the answers may increase the future prosecutor's burden of 
Even if the premise of the protective taint approach were sound, compelling a response may prevent the government from prosecuting the invoker. When the plaintiff asks the court to overrule a privilege claim based on prospective taint, he is not merely asking the court to decide the taint issue. In effect, the plaintiff is asking the court to grant the invoker use immunity for his compelled testimony ${ }^{168}$ Because the testimony will never be identical to that given before, the compulsion order will increase the amount of immunized testimony and broaden the scope of the previous immunity. If the government learns of any newly compelled testimony or information derived from that testimony, ${ }^{169}$ it will find it even more difficult to show at a later prosecution that its evidence has not been derived directly or indirectly from any immunized testimony. Indeed, the proliferation of immunized testimony tends to convert use immunity into transactional immunity.

The intrusion on the authority of the executive branch is not merely theoretical. Assume that the government, after giving use immunity, cut short its questioning in order to limit the immunized testimony and maintain its option to prosecute. The court's later decision to compel the invoker to testify may foreclose that option if the invoker seizes the opportunity to fill the record with highly incriminating responses. Once the government learns of those responses or information derived from them, it may no longer be able to show lack of taint. Whatever the harm done, the judge's decision to compel testimony destroys the government's control of the scope of immunity.

Yet, the government, which may be the only.party adversely affected by compelling the testimony, is not before the court. Nor do any of the parties before the court share the government's interest in restricting the scope of immunity in order to maintain the option to prosecute. The plaintiff surely cannot be relied upon to point out the possible absence of taint, since he wants the response compelled. On the contrary, the plaintiff can be expected to affirm that all his questions are derived from immunized testimony. The invoker, at least on some occasions, will also desire

showing that his other evidence has not been tainted. The disputes invited by this approach threaten to require the court's presence at the depositions.

168. Cf. Adams v. Maryland, 347 U.S. 179, 181 (1954) ("[A] witness does not need any statute to protect him from the use of self-incriminating testimony he is compelled to give over his objection."); In re Folding Carton Antitrust Litig. (Appeal of Brown), 609 F.2d 867, 872 n.11 (7th Cir. 1979) (citing Adams).

169. Compelled testimony given in the private civil suit and information derived from it may reach the government through several channels: the attorneys, parties, and witnesses in the private case, the press, or the rumor mill. Even a protective order will not prevent the information from spilling out at a civil trial and then reaching the government indirectly. The tainted information may reach the government even when government officials, in an attempt to maintain their option to prosecute, strive to remain uninformed. 
the immunity he may receive when his testimony is compelled. While the defendant will often want the invokings upheld, it will not necessarily be a party to the plaintiff's motion to overrule these invocations. Nor is it likely to share the government's concern about foreclosing future prosecution. Admittedly, some courts employing the prospective taint approach may know that the current government officials, as a practical matter, are not interested in any further prosecution of the invokers. Nevertheless, the failure of the approach to involve the government, despite the possible adverse effect on the government, constitutes a serious flaw. The need for government involvement requires that any decision about taint be reserved until the government attempts to introduce allegedly tainted evidence in a prosecution. Then the court is able to determine the taint issue with the benefit of the government's views and the benefit of knowing what the questions and responses turned out to be. ${ }^{170}$

\section{B. Remedies to Allow}

A combination of remedies, to be imposed consistently whenever defendants or their employees invoke in civil cases, offers a better judicial response than either the remedies just discussed or an attempt to devise remedies case by case. ${ }^{171}$ An outline of the proposed combination of remedies, shorn of qualifications and exceptions, follows.

First, any invokings by defendants or their employees during the civil case should be revealed to the factfinder at the civil trial. The factfinder should learn the circumstances surrounding the invoking, such as the inquiries put to the invoker and the nature of the discovery requests in response to which the invoking occurred. The plaintiff's attorney should be allowed to inform the factfinder of the use of the privilege and the surrounding circumstances without having to call the invoker to the stand. The plaintiff also should be entitled to an instruction clarifying that the jury may consider the use of the privilege insofar as it tends to establish the facts in issue. Second, when use of the privilege by defendants or their

170. The Fifth Circuit cited the need for involvement by the government in rejecting the prospective taint approach. In re Corrugated Container Antitrust Litig., 620 F.2d 1086, 1093 (5th Cir. 1980).

171. A few courts have opted to devise remedies case by case by applying a balancing test. E.g., Constanza v. Constanza, 66 N.J. 63, 328 A.2d 230 (1974); Mahne v. Mahne, 66 N.J. 53, 328 A.2d 225 (1974); see Note, The Self-Incrimination Privilege in Civil Discovery, 1970 WASH. U.L.Q. 371, 373. This test calls for consideration of such matters as whether the invoker is likely to be prosecuted and whether the plaintiff is likely to find other evidence of equal value to that which the invoker's response would probably have provided. Such an approach fails to indicate before the invoking the remedies that will follow, forces the court to speculate about future developments, and invites lengthy disputes. Any uncertainty about the remedies for plaintiff after invokings by defendants and their employees reduces the settlement value of the plaintiff's case and thereby encourages strategically motivated invokings. The goal of encouraging defendants and their employees to invoke only when they genuinely fear prosecution requires predictable remedies. 
employees contributes substantially to the plaintiff's failure of proof, the court should place on the defendants the burden of showing that they have not engaged in the conduct alleged by the plaintiff. Third, defendants and their employees should be barred from later waiving the privilege and testifying at trial unless they waive the privilege and submit to discovery a sufficient time before trial to avoid prejudice to the plaintiff.

These remedies offer several benefits. They require no new legislation. They allow the courts to adhere to current Fifth Amendment standards. They stop short of granting a judgment against the defendant. If consistently imposed, they will clarify the effects of invoking for all involved. Taken together, they offer a chance of opening up discovery by inducing defendants and their employees to invoke only when the danger of prosecution is genuine. Yet by maintaining without restriction the opportunity to invoke, they protect those in genuine danger of prosecution from facing the cruel trilemma of incrimination, perjury or contempt. While they tend to offset the disadvantage imposed on plaintiffs, they do little or no violence to constitutional, procedural ${ }^{172}$ or evidentiary principles.

\section{Informing the Factfinder}

Presently, many jurisdictions allow the factfinder to learn under some circumstances that the defendant himself has invoked. ${ }^{173}$ For instance, a plaintiff is often allowed to call the defendant to the witness stand, even though he realizes that the defendant will invoke. ${ }^{174}$ Some jurisdictions also refuse to instruct the jury to disregard the use of privilege. ${ }^{775}$ Some go still further and allow the plaintiff to refer during argument to the defendant's use of the privilege and to ask the factfinder to draw appropriate inferences. ${ }^{176}$ But even these disclosures of the defense's use of the privilege at trial draw criticism. ${ }^{177}$ Moreover, it is not clear that the defendant's use of the privilege during discovery can always be brought to the jury's

172. The remedies are fully consistent with the Federal Rules of Civil Procedure in that no Rule 37 sanctions are imposed against the invoker or his employer.

173. The differences among jurisdictions are summarized in $8 \mathrm{~J}$. WIGMORE, supra note 31 , 2272 , at 439 n.14.

174. E.g., In re Baun, 395 Mich. 28, 35-37, 232 N.W.2d 621, 624-25 (1975) (opposing party may call party who has indicated he will invoke).

175. See, e.g., Bradley v. O'Hare, 2 A.D.2d 436, 442, 156 N.Y.S.2d 533, 540 (N.Y. App. Div. 1956); Crowley v. Crowley, 18 Misc. 2d 586, 589, 186 N.Y.S.2d 60, 63 (Sup. Ct. 1959); Grognet v. Fox Valley Trucking Serv., 45 Wis. 2d 235, 239, 172 N.W.2d 812, 815 (1969).

176. See, e.g., Morris v. McClellan, 154 Ala. 639, 45 So. 641 (1908); Hinton \& Sons v. Strahan, 266 Ala. 307, 96 So. 2d 426, 429 (1957) (citing Morris). But see In re Woll, 387 Mich. 154, 194 N.W.2d 835 (1972) (invoking may not be subject of comment).

177. Some courts have held that an invoking party in a civil case should suffer no adverse consequences from his exercise of the privilege. See, e.g., Depew v. Hanover Ins. Co., 73 F.R.D. 101 (E.D. Tenn. 1976) (jury should be instructed to disregard party's invoking); $c f$. Shaneff v. Sabo, 251 Ind. 229, 240 N.E.2d 820 (1968) (error to force plaintiff to assert doctor-patient privilege before jury); supra note 78 (discussing proposed FED. R. EVID. 513). 
attention, that such assertions of the privilege can be brought to the jury's attention without the invoker being called as a witness, that an instruction can be obtained allowing the jury to consider the assertions of the privilege insofar as they constitute relevant evidence, or that the use of the privilege by the defendant's employees can be used against the defendant itself. ${ }^{178}$

The objections to telling the jury about assertions of the privilege by the defendants and their employees fall into two categories. There is first the constitutional objection, that allowing the jury to learn of the defendant's use of the privilege so burdens the defendant's privilege as to violate his Fifth Amendment rights. The second objection is loosely termed the evidentiary objection, that assertions of the privilege should not be brought before the jury because they do not constitute relevant and admissible evidence. ${ }^{179}$

\section{a. The Constitutional Objections}

The constitutional objections to drawing an inference against an invoking defendant in a civil case draw support from several Supreme Court decisions, and have led to sharp disagreements among the lower courts. ${ }^{180}$ In Griffin v. California, the Supreme Gourt forbid any comment on the defendant's failure to testify in a criminal case. ${ }^{181}$ Grunewald v. United States $^{182}$ and Doyle v. Ohio ${ }^{183}$ also forbid any reference at trial to a crimi-

178. See Moxham, A Comment Upon the Effect of the Exercise of One's Fifth Amendment Privilege in Civil Litigation, 12 NEW ENG. L. REV. 265, 266 (1976) (inference can be drawn only when party invokes and not when witness invokes).

Some states that refused to adopt proposed Rule 513 , see supra note 78 , forbidding any inference from, or comment or jury instruction on a party's use of the privilege, and mandating that to the extent possible juries be kept uninformed about invokings, nevertheless follow similar rules when a witness, not a party, invokes. E.g., ME. R. EvID. 512, 513. These rules have the effect of treating an employee of a corporate party, even a president or chief operating executive, as a neutral witness.

179. This objection ignores the claim that equitable considerations, namely the need to open up discovery and redress the disadvantage imposed on the plaintif by the defense's use of the privilege, in themselves call for revealing the invokings. Such an equitable justification would ignore relevance and admissibility. One hesitates to embrace such an equitable rule, however, since the invokers have not violated any procedural principle and since the danger exists that the jury may consider the invokings for improper and highly prejudicial purposes. Hence, we should examine to what extent admitting the invokings can be justified on evidentiary grounds while keeping in mind that other reasons for admitting them exist.

180. Compare Buzard v. Griffin, 89 Ariz. 42, 48, 358 P.2d 155, 158 (1960) (allowing inference) with Frierson v. McIntyre, 151 F. Supp. 5, 6-7 (W.D. Va. 1953) (inference unconstitutional).

181. 380 U.S. 609 (1965). In Griffin the no-comment rule in criminal cases was found to be required by the Fifth Amendment itself. A similar result was reached in Brooks v. Tennessee, 406 U.S. 605 (1972) (state statute requiring criminal defendant to testify before other defense witnesses or not at all violates defendant's Fifth Amendment privilege). Griffin has recently come under attack. See, e.g., Ayer, The Fifth Amendment and the Inference of Guilt from Silence: Griffin v. California Afier Filieen Years, 78 MicH. L. REV. 841 (1980).

182. 353 U.S. 391 (1957).

183. 426 U.S. 610 (1976). 
nal defendant's use of the privilege before the grand jury or at the time of arrest, even to impeach a criminal defendant who had testified to his innocence. ${ }^{184}$

More important, a long line of non-criminal cases forbids the states from denying public employment, cancelling government contracts, or disbarring attorneys based on the use of the privilege. ${ }^{185}$ Some of these cases played a major role in obstructing government efforts to purge political dissidents from public employment. ${ }^{186}$ These cases emphasize that "no cost" may be imposed on a use of the privilege.

But in Baxter v. Palmigiano, ${ }^{187}$ the Burger Court put the constitutional objection to rest. Palmigiano was a prisoner charged in a disciplinary hearing with inciting a disruption of prison operations. Warned that his testimony at the hearing might be used to prosecute him but that his failure to testify would be held against him by the Disciplinary Board, he invoked the privilege and refused to testify. After hearing other evidence, the Board ordered him placed in punitive segregation and reclassified downward.

The Supreme Court assumed on appeal that the Board had drawn an adverse inference from Palmigiano's invoking and upheld the Board's action. Justice White strictly limited Griffin's ban on drawing inferences from invokings to criminal proceedings. He indicated that the "no cost" line of cases, none of which involved criminal proceedings, applied only when the invoking resulted in automatic imposition of some sanction and

184. Grunewald, 353 U.S. at 415-24. In Jenkins v. Anderson, 447 U.S. 231 (1980), the Court said the defendant's failure to report a killing for several days could be used to impeach a claim of self-defense. Doyle v. Ohio, 426 U.S. 610 (1976), was distinguished on the ground that there the government, by warning the defendant of his right to remain silent, had in effect encouraged him to remain silent; hence, holding his silence against him would offend due process. Jenkins, 447 U.S. at 239-40. That Doyle is said to rely on the due process clause rather than on the privilege against selfincrimination is significant. It suggests that a defendant's use of the privilege at a grand jury or other pre-trial proceeding may be used later to impeach his trial testimony, as long as the invoking was not encouraged or induced by the prosecutor. Jenkins also reaffirmed Raffel v. United States, 271 U.S. $494,497-98$ (1926), which allowed the prosecution to impeach the defendant with his refusal to testify at his earlier trial for the same offense. Jenkins, 447 U.S. at 235.

Grunewald, which barred impeachment use of invokings occurring before the Grand Jury, had put Raffel in doubt. Jenkins now puts Grunewald in doubt.

185. In each case, a statute or regulation established that some non-criminal sanction, such as loss of government employment, would follow any invoking; in each, the invoking occurred during a proceeding brought by the state. E.g., Lefkowitz v. Turley, 414 U.S. 70 (1973) (government contracts); Uniformed Sanitation Men Ass'n v. Comm'r of Sanitation, 392 U.S. 280 (1968) (employment with sanitation department); Spevack v. Klein, 385 U.S. 511 (1967) (attorney discipline proceeding).

186. E.g., Slochower v. Board of Higher Educ., 350 U.S. 551 (1956). In contrast, civil cases between private parties are not vehicles for state investigations and harrassment of political dissidents. Nor do they often concern the exercise of First Amendment rights. But see Independent Prods. Corp. v. Loew's, Inc., 22 F.R.D. 266 (S.D.N.Y. 1958) (antitrust plaintiffs, producers of blacklisted film, hampered by a claim of privilege that may have been required to defiect inquiries into their political beliefs and associations).

187. 425 U.S. 3089 (1976). 
when no other evidence of the conduct at issue had been received.

If a prison disciplinary hearing is not sufficiently akin to a criminal prosecution for Griffin's no-comment rule to apply, Griffin plainly cannot govern a private civil case. The penalties imposed at the prison hearing included increased confinement and loss of liberty, higher stakes than those in a civil case. The opposing party was the state, with its power to offer use immunity if it wanted Palmigiano's information. Giting Wigmore, Justice White took as settled that "the Amendment 'does not preclude the inference where the privilege is claimed by a party to a civil cause." "188

As narrowed by Baxter, the "no-cost" line of cases would require only that the invokings of civil defendants and their employees not form the sole ground for plaintiff's recovery. Moreover, the "no-cost" cases may be distinguished altogether from private civil cases because, in each of the former cases, it was a government entity that was imposing sanctions for invoking. Such conduct raises the fear, absent in the private suit, of governmental attempts to coerce incriminating disclosures, thereby circumventing the limits on discovery in criminal cases.

Justice Brennan's Baxter dissent, in which Justice Marshall joined, sharply criticized the majority's narrow reading of the "no-cost" cases. The dissenters read those cases to forbid the government from imposing any substantial sanction on a person who chooses to invoke the privilege rather than answer questions posed by the government. The two Justices plainly were concerned with governmental coercion of disclosures through threats of non-criminal sanctions: left unchecked, the government might use such sanctions to circumvent the normal limits on criminal discovery. Significantly, however, even the dissenters would have allowed an adverse inference to be drawn from an invoking in a private civil suit, where prophylactic "foxhunter" policies designed to keep the government from abusing its powers do not operate:

In a civil suit involving only private parties, no party brings to the battle the awesome powers of the government, and therefore to permit an adverse inference to be drawn from exercise of the privilege does not implicate the policy considerations underlying the privilege. But where the government "deliberately seeks" the answers to incriminatory questions, allowing it to benefit from the exercise of the privilege aids, indeed encourages, governmental circumvention of our adversary system. ${ }^{189}$

188. Id. at 318 (quoting $8 \mathrm{~J}$. WIGMORE, supra note 31, at 439 (emphasis in Baxter)).

189. 425 U.S. at 335. 
Hence, the "no-cost" cases, even as read by Justices Brennan and Marshall, do not bar drawing an adverse inference against the invoker in a private civil case. The lack of concern about government overreaching in private civil cases combines with the enhanced concern about fair treatment for the plaintiff, who, unlike the government, is relatively powerless to overcome the disadvantage imposed by the defense use of the privilege.

Baxter not only settled the issue of whether adverse inferences could be drawn in a non-criminal proceeding but the converse of that issue as well. The converse issue is whether a potential invoker who waives the privilege and responds in order to avoid non-criminal sanctions may later prevent use of his response in a criminal case against him on the ground that his response was "compelled" in violation of his Fifth Amendment rights. Palmigiano, for instance, could have raised this issue by responding in the disciplinary hearing and then moving to prevent any use of his testimony during his subsequent prosecution. The grounds for his suppression motion would have been that the non-criminal sanctions for invoking, namely the drawing of an adverse inference in the disciplinary proceeding, compelled his response. Indeed, many cases have presented this scenario, and guidelines have been developed for determining which non-criminal sanctions are so severe that they compel the waiver of the privilege. ${ }^{190} \mathrm{But}$ constitutionally permissible sanctions for invoking will not, by definition, compel a waiver. Thus, Baxter necessarily implies that Palmigiano's testimony at the disciplinary hearing, should he have decided to respond, would not have been compelled and could have been used against him in a later prosecution. ${ }^{191}$ Similarly, no testimony given in a civil case by a person who could have invoked will be considered compelled, even though the invoking would have led to an adverse inference in the civil case.

Other cases also indicate that the "sanction" of allowing an adverse inference to follow from an invoking does not render the response "compelled." In McGautha v. California, ${ }^{192}$ the guilt and sentence of a defendant charged with murder were determined in a unitary trial; as a result of invoking the privilege by declining to testify during the trial the defendant also lost his opportunity to testify for a lenient sentence. Upholding the unitary trial despite this sanction, Justice Harlan asserted that testimony will not be considered "compelled" merely because negative consequences may attend an invoking:

190. See, e.g., Garner v. United States, 424 U.S. 648 (1976); Simmons v. United States, 390 U.S. 377 (1968); Garrity v. New Jersey, 385 U.S. 493 (1967).

191. Since Baxter, lower courts have ruled that statements uttered during probation revocation hearings are not "compelled." E.g., Ryan v. Montana, 580 F.2d 988 (9th Cir. 1978).

192. 402 U.S. 183 (1971). 
The criminal process, like the rest of the legal system, is replete with situations requiring "the making of difficult judgments" as to which course to follow. Although a defendant may have a right, even of constitutional dimensions, to follow whichever course he chooses, the Constitution does not by that token always forbid requiring him to choose. The threshold question is whether compelling the election impairs to an appreciable extent any of the policies behind the rights involved. ${ }^{193}$

Specifically, Harlan found that allowing adverse evidentiary consequences to follow from an invoking would not render the response compelled: "It is not contended, nor could it be successfully, that the mere force of evidence is compulsion of the sort forbidden by the [Fifth Amendment] privilege."194

Since the 1976 Baxter decision the Court has continued to allow adverse inferences to be drawn from the use of the privilege in civil cases. Although in Lefkowitz v. Cunningham, ${ }^{195}$ the Court struck down a New York statute requiring an officer of a political party to waive the privilege under certain circumstances, it carefully adhered to the narrow reading of the "no-cost" cases. Under that statute, invoking the privilege triggered immediate dismissal from party office and a five-year ban on holding any other party or public position. Thus, the case presented the kind of sanction forbidden by the "no cost" cases, a sanction automatically imposed solely for invoking the privilege in response to an inquiry from the government. The Court distinguished Baxter in a footnote: "Baxter did no more than permit an inference to be drawn in a civil case from a party's refusal to testify. Respondent's silence in Baxter was only one of a number of factors to be considered by the finder of fact in assessing a penalty . . . ."196

Hence, the majority and dissenting opinions in Baxter establish that an invoking in a civil case may constitutionally lead to an adverse inference against the invoker and may be the subject of comment by opposing counsel. As long as the invoking and any attendant inference do not constitute the sole basis for the judgment against the invoker, no constitutional objection is warranted. Whether the Constitution would permit the granting of a default judgment against a defendant for his invoking in a civil case, however, is less clear.

More generally, Harlan's suggestion in McGautha that the constitutional issue raised by any remedy given the plaintiff must turn on the

193. Id. at 213.

194. Id.

195. 431 U.S. 801 (1977).

196. Id. at 808 n.5. 
extent to which the remedy impairs any of the policies behind the privilege throws attention back to the policy analysis in Part III. There we saw that the "fox hunter" policies behind the privilege are not seriously implicated in civil cases between private parties. The policies that are implicated in these cases, such as the policies against the cruel trilemma, will not be offended by remedies that only tend to increase the invoker's civil exposure.

\section{b. The Evidentiary Objections}

The evidentiary objections to bringing invokings to the attention of the factfinder assume that the factfinder should determine the issues in a civil case only upon admissible evidence and the legal instructions of the court. Invokings, especially out-of-court invokings, must therefore carry evidentiary significance in themselves to come before the factfinder. This part of the article, accordingly, evaluates the evidentiary objections, notes the procedural benefits of treating past invokings as admissible evidentiary events, and then posits a theory for admitting invokings under conventional evidence principles.

\section{i. The Need for an Evidentiary Status}

A jury often learns about invokings without the court deciding whether the invokings are admissible evidence. When a defendant invokes while testifying as an adverse witness, for example, the jury will see the invoking. Defense counsel, feeling that enough damage has already been done, may choose not to force the court to decide whether the invokings ought to be admissible. But the defendant can argue that, unless the court accepts the invokings as admissible evidence, it should instruct the jury to disregard them, and that the court should grant defense counsel's request before trial to prevent the plaintiff from calling to the stand a defendant who is certain to invoke. ${ }^{197}$ Finally, ethical standards may restrict efforts to bring to the jury's attention any assertion of a privilege that is not itself admissible evidence. ${ }^{198}$

Even if the court allows a plaintiff at trial to call a defendant or his employee who has invoked and has indicated that he will invoke again, the privilege still provides a potent weapon for the defense unless out-of-

197. This was, of course, the treatment mandated by Proposed Rule 513 of the Federal Rules of Evidence. See supra note 78.

198. AMERICAN BAR ASSOCIATION, STANDARDS FOR CRIMINAL JUSTICE, THE DEFENSE FunCTION 7.6(c) provides that an attorney should not attempt to alert the jury to a person's use of the privilege. Ethical Consideration 7-25 also provides that a lawyer should not put before a jury matters that it cannot properly consider. AMERICAN BAR ASSOCIATION, SPECIAL COMMITTEE ON EVALUATION OF ETHICAL STANDARDS 83. 
court invokings are themselves admissible evidentiary events. For example, a defendant's employee who has invoked during a deposition may use the privilege to deflect discovery while he is available to the plaintiff, but then may avoid the need to invoke before the jury by making himself unavailable at the time of trial. Unless his out-of-court invokings are admissible in their own right, the jury may never learn of them. Moreover, a plaintiff required to call the invoking defendant and employees to testify at trial in order to bring out their invokings will be forced to run undue strategic risks. When called, the witnesses may waive the privilege and proceed to give harmful testimony. Even if the court strikes this testimony on the ground of unfair surprise, the jury might feel that the plaintiff is obstructing the case by refusing to let the witnesses testify. Once the witnesses are off the stand, it is not clear that the plaintiff can inform the jury of the witnesses' earlier invokings. Furthermore, even if the "testimony" goes as planned, with the witnesses invoking as they did at their deposition, the jury may feel that the plaintiff's counsel unnecessarily embarrassed the witnesses, especially if the jury learns that he knew in advance that the witnesses would invoke. Indeed, calling witnesses to the stand so that the jury may see them invoke is a contrived and unseemly procedure, which would become unnecessary if the out-of-court invokings themselves were admissible.

Courts have suggested several evidentiary theories for admitting a defendant's out-of-court invokings. When a defendant who has previously invoked takes the stand and provides testimony that does not seem to incriminate him, courts have admitted his previous invokings as prior inconsistent statements. ${ }^{199}$ But in order to qualify as prior inconsistent statements, the earlier invokings must be found sufficiently inconsistent with the defendant's in-court testimony. Because even the innocent may properly invoke, and because the invoker's reason for believing his response incriminating probably never was explored, establishing an inconsistency might prove difficult. Moreover, this approach still allows defendants and their employees who invoke to block the plaintiff's discovery and to conceal their version of events until trial. Hence, the prior inconsistent statement approach, which applies only when the invoker takes the stand, does not resolve the plaintiff's dilemma. ${ }^{200}$

Another evidentiary theory for admitting prior invokings would treat

199. The prior inconsistent statement rationale has been employed even against the defendant in criminal cases. In Raffel v. United States, 271 U.S. 494 (1926), which was reaffirmed in Jenkins v. Anderson, 447 U.S. 231, 235 (1980), a criminal defendant was impeached for his failure to testify at a previous criminal trial.

200. If, as this Article recommends, a defendant or employee who has invoked throughout civil discovery is barred from testifying at trial, the prior inconsistent statement rationale need not be considered. 
them as silence in the face of an incriminatory accusation. Silence under such circumstances has been considered an admission that the accusation is correct. The theory is that the natural reaction of an innocent man to an untrue accusation is a prompt denial; silence, therefore, shows consciousness of guilt. As the Supreme Judicial Court of Massachusetts declared:

Instant impulse, spontaneous anxiety and deep yearning to repel charges thus impugning his honor would be expected from an innocent man . . . . In the face of such accusations, men commonly do not remain mute but voice their denial with earnestness, if they can do so with honesty. Culpability alone seals their lips. ${ }^{201}$

Thus, the accusations, the surrounding circumstances, and the defendant's silence in response have been held admissible. ${ }^{202}$ This principle has even been extended to admit all statements made in the party's presence, unless the party can show that he lacked either the opportunity or the motive to deny their accuracy. ${ }^{203}$

But the invokings-as-silence theory is inadequate. First, invokings will not necessarily occur in response to an assertion or to a question containing an assertion..$^{204}$ More often, invokings follow open-ended questions that are free of assertions, such as questions that ask a deponent what he did on a particular night. Invoking in response to such a question, while appropriate under current standards, hardly shows assent to any assertion. It illustrates only the invoker's belief that a complete answer might at least provide a clue that would lead to incriminating evidence. Second, the invokings-as-silence theory assumes that the natural response of the innocent to an incriminatory accusation will be a spontaneous and emphatic denial. But this assumption is suspect in the atmosphere of most depositions, where the deponent strives to stay calm and to produce a helpful record through cautious wording of all replies. In this setting the innocent should hardly be expected to respond with the righteous outrage described by the Massachusetts court.

\section{ii. Invokings as Statements of a Party}

We have seen the shortcomings of the current evidentiary theories for admitting past invokings. Granted, a statement claiming a privilege rather

201. Attorney Gen. v. Pelletier, 240 Mass. 264, 316, 134 N.E. 407, 423 (1922).

202. C. MCCORMICK, supra note $48, \S 270$ (b).

203. Id.

204. An example of a question containing an assertion would be: "Mr. Defendant, you and your gang assaulted the plaintiff because he was black, didn't you?" Under the invoking-as-silence approach, invoking in response to such a question tends to admit the assertion. 
than attempting to respond to an inquiry does not fit squarely into any evidentiary category. ${ }^{205}$ Nevertheless, some distinctions are possible. A refusal to respond on the ground of attorney-client, doctor-patient, or spousal immunity does not say or imply anything about the content of the withheld response. It suggests only that the response would betray information that was revealed under certain circumstances by the client, patient or spouse. In contrast, a refusal to respond on the ground that one's answer might tend to incriminate one does say something about the content of the response that, depending on the question and the surrounding circumstances, may tend to prove relevant facts in the civil case.

Accordingly, such a statement by a party may, with modest stretching of evidentiary principles, merit the same treatment as most statements of a party: the party's invoking would be considered an assertion of his belief that his response might tend to incriminate him. Hearsay issues would not arise from the lack of cross-examination because statements of a party are excluded from the definition of hearsay, at least under the Federal Rules of Evidence and the law of most states. ${ }^{206}$

The theories for admitting statements of a party when offered by an adverse party seem to rely more on common sense than on a discrete or sophisticated rationale. Upon examination, however, the theories apply as well to the statement that one's response may incriminate him as to other statements of a party. One theory holds, for example, that the rule permitting the admission of statements of a party-opponent stems from the premises of the adversary theory of litigation: a party should not be allowed to claim that his own prior declarations are too untrustworthy to be admitted. ${ }^{207}$ Professors Louisell and Mueller have expressed the theory as follows:

Given that a party bears the lion's share of responsibility for making or breaking his own case, it is reasonable to conclude that he is in no position to claim that his own statement should be excluded because not . . . subject to cross-examination, under circumstances enabling the trier of the fact to observe demeanor . . . Again the philosophy of the adversary system implies the judgment that it is fair to put a party at risk that the trier will accord full evidential force to his own statement unless he comes forward with some kind of counterproof

205. The statements required to invoke a privilege have not been treated as admissible evidence in themselves. When the marital communications privilege, attorney-client privilege, or physician-patient privilege is invoked, neither an adverse inference nor a comment is allowed. $8 \mathrm{~J}$. WIGMORE, supra note $31, \S \S 2243,2322,2386$.

206. FED. R. EvID. 801 (d)(2)(A) provides that "[a] statement is not hearsay" if it is "offered against a party and is . . . his own statement, in either his individual or a representative capacity . . . "The evidence codes of several states are identical. E.g., NEB. REV. STAT. § 27-801(4)(b)(i) (1979).

207. See C. MCCORMICK, supra note 48, § 262. 
... ${ }^{208}$

Wigmore has added that a party's statements also are admissible under the same logic that admits prior inconsistent statements. They are inconsistent not with the party's testimony, for he may have not testified, but with his pleadings - or with the very fact of his opposition to the opposing party's claims. The inconsistency is equally discrediting and admissible on that basis. According to Wigmore, the inconsistency between the statement and the party's position need not be apparent; it will be presumed from the fact that the opposing party is the one offering the statement. ${ }^{209}$ Again, the rationale applies as much to the invoking statements that one's response would tend to incriminate him as to any other statements of a party.

Taking a different approach, Professor Strahorn has contended that out-of-court statements of a party should be admissible because they provide relevant circumstantial evidence of the party's conduct. Such statements may furnish a basis for an inference as to the the party's state of mind, in turn allowing an inference as to the facts that produced that state of mind. This theory also warrants admitting invokings as much as any other statements. The invoking creates an inference that the invoker believed his response would incriminate him, and that in turn may create an inference about his conduct. ${ }^{210}$

When offered against the invoking party, his out-of-court statement that his response would tend to incriminate him is at least as reliable as most statements of a party. The invoking statement is uttered in the course of a formal proceeding, after the party and his counsel have had an opportunity to consider their response. It is a sufficiently grave admission that parties who resort to it are likely to have reviewed and reflected on their past actions beforehand. ${ }^{211}$

Treating a defendant's invoking as a statement of a party assists the plaintiff substantially. First, the statement would be admissible for all purposes, including showing that a complete response would tend to incriminate the invoker. Second, the out-of-court invoking could be introduced as evidence without the plaintiff having to call the invoking defendant to the stand; thus, the plaintiff would control whether and when the

208. 4 D. LOUISELL \& C. MUELLER, FEDERAL EVIDENCE 250-51 (1980).

209. 4 J. WIGMORE, EVIDENCE § 1048 (J. Chadborne rev. ed. 1972).

210. See generally Strahorn, A Reconsideration of the Hearsay Rule and Admissions, 85 U. PA. L. REV. 484, 491-93 (1937) (discussing utterances as circumstantial evidence).

211. Granted, when most out-of-court statements of a party are admitted, the party will be able to testify and attempt to explain his statement at trial. This will not be the case if, as recommended here, the party's invoking bars him from testifying. But the party's capacity to testify is not a prerequisite for admitting his earlier statement. See C. MCCORMICK, supra note 48, § 263. 
invokings are disclosed. Third, the invokings would be admissible despite being in the form of an opinion. Fourth, the plaintiff would not need to show that the invoking was against the defendant's interest. ${ }^{212}$

Moreover, treating a defendant's invoking as a statement of a party allows the plaintiff to introduce the defendant's past invokings regardless of where they occurred-in the defendant's answer, in his reply to the plaintiff's interrogatories or requests for admissions or documents, or at his deposition. The invoking would be admissible even though the defendant later changed his mind, waived the privilege, and submitted to discovery. Finally, past invokings would be admissible even when the privilege is no longer available due to the running of the statute of limitations or the attachment of jeopardy. ${ }^{213}$

\section{iii. Employee Invokings as Vicarious Statements of a Party}

When the defendant is a corporation, the privilege is used most frequently by the corporation's employees at depositions. The corporate defendant's strategy may call for its employees to invoke at every opportunity. Again, the appropriate remedy is to enable the plaintiff to bring these invokings to the jury's attention and to argue whatever inferences against the defendant corporation they provide.

An invoking by an employee during a deposition should be treated as a vicarious statement of the defendant corporate employer if the invoker was still working for the defendant corporation at the time of the invoking and if the question that triggered the invoking related to the employee's work. ${ }^{214}$ If invokings are treated as vicarious statements of the corporate

212. Of course, the party remains free to show by other evidence that his response would not have incriminated him.

213. An alternative theory for admitting a party's out-of-court invoking would treat the invoking as an admission by conduct. The closest analogy is to a party's refusal to submit upon request to a physical examination. When the discovery rules allowed a party to refuse a physical examination, the opposing party was entitled to inform the factfinder of his opponent's refusal and to argue appropriate inferences. See Texas \& N.O. Ry. v. Rooks, 292 S.W. 536 (Tex. Comm'n App. 1927); 8 J. WigMORE, supra note $31, \S 2220$, at 195 .

When physical examinations became compulsory, see C. MCCORMICK, supra note 48, at $656 \mathrm{n} .25$, the need for an adverse inference against the party refusing the examination vanished since that party could be subjected to sanctions under FED. R. CIV. P. 37. If an opposing party never attempted to compel his opponent to submit to a physical examination, no inference against the opponent would exist. Thus, as the discoverability of the information that the opposing party secks to suppress increases, the reason and need for admitting the efforts to suppress decrease. In contrast, the privileged material that the invoker has suppressed is not discoverable, and hence the reason and need to admit the invoking is substantial.

214. See Ralph Hegman Co. v. Transamerica Ins. Co., 293 Minn. 323, 198 N.W.2d 555 (1972). The same treatment should be accorded invokings of the employee whether they occur in response to interrogatories, other discovery requests, or questions at trial.

That the invoker is no longer the defendant's employee at the time of his invokings need not necessarily bar admitting the invokings as a vicarious admission. The fact of present employment serves primarily to reduce the chance that the employee will falsely claim to have engaged in criminal con- 
party-opponent, they will be exempt from the hearsay rule as long as they relate to a matter within the scope of the invoking employee's employment. ${ }^{215}$ If the employee is authorized to perform certain acts, his statements about those acts will be treated as statements of the employer. ${ }^{216}$

The policies for admitting the statement of an employee against his employer, despite his the employer's inability to cross-examine the employee at the time of the statement, apply as much to an invoking at the employee's deposition as to other vicarious statements. At least four factors support the reliability of employee statements. ${ }^{217}$ First, employees are not likely to jeopardize their jobs by making false statements that discredit their corporate employers. If the other remedies suggested here are imposed, an employee at a deposition would have every incentive to exculpate his corporate employer if he could. Corporate counsel would have ample opportunity to explain the corporation's interest to the deponentemployee. The chance is remote that an employee would invoke in order to suggest that his corporation is guilty of criminal conduct when it is not. And as long as the deposition questions concern the employee's activities in his work for the defendant corporation, the chance is also remote that the employee would invoke because his response would incriminate him personally even though the corporate employer is innocent. ${ }^{218}$

Second, the reliability of vicarious statements is supported by the probability that the speaker will be well informed when the subject concerns matters within the scope of his employment. Invokings would share this reliability as long as the questions in reply to which the invokings occur concern the employee-deponent's work.

Third, the employer against whom a vicarious statement is offered will

duct for which the defendant employer is liable. Any factors suggesting that a former employee retains some loyalty to his former employer-such as the fact that the employer is paying for his attorney-would serve the same purpose.

215. See FED. R. EVID. 801(d)(2)(D) ("A statement is not hearsay if . . . [it] is offered against a party and is ... a statement by his agent or servant concerning a matter within the scope of his agency or employment, made during the existence of the relationship . . ..") This section climinated the need to show that the employee had "speaking authority."

216. $4 \mathrm{~J}$. WEINSTEIN \& M. BERGER, supra note $78, \S 801(\mathrm{~d})(2)(\mathrm{D})[01]$, at 801-158 to -162 .

217. See, e.g., 4 D. LOUISELL \& C. MUELlER, supra note 208, at 318-22 (discussing factors supporting admission of vicarious statements).

218. Corporations and partnerships are often prosecuted for the criminal activities of employees acting within the scope of their employment. See, e.g., United States v. A\&P Trucking Co., 358 U.S. 121 (1958); Standard Oil Co. v. United States, 307 F.2d 120, 125 (5th Cir. 1962); Continental Baking Co. v. United States, 281 F.2d 137, 149 (6th Cir. 1960). Some courts have found that an adverse inference may be drawn against a corporation from invokings by its employees or agents. E.H. Boerth Co. v. LAD Properties, 82 F.R.D. 635, 644-45 (D. Minn. 1979); Ralph Hegman Co.. v. Transamerica Ins. Co., 293 Minn. 323, 198 N.W.2d 555 (1972).

The assumption in the text is that the plaintiff is suing the defendant corporation based in part on the work-related actions of the invoking employee. Of course, if the corporation or its stockholders are suing the employee for actions harming the corporation, no inference against the corporation would arise. 
generally have access to evidence that explains or rebuts the matter asserted, if any such explanation or rebuttal is possible. ${ }^{219}$ This holds true when the employee-deponent invokes, for the defendant corporation may call fellow employees or produce internal documents to explain why the employee's invoking does not establish its criminal or civil liability.

Finally, a deponent-employee's assertion that his response will incriminate him carries an added element of reliability because it is ordinarily made under oath. Other types of vicarious statements that are admissible under the Federal Rules of Evidence and their state equivalents frequently are not. ${ }^{20}$

The plaintiff will benefit substantially from being able to treat the employee's invoking as a vicarious statement of the employer. He will be able to offer the statement into evidence for any purpose, even though it is in the form of a conclusion. ${ }^{221} \mathrm{He}$ will be able to read the statement and the accompanying questions to the jury whenever he wishes. And he will not need to call the invoker to the stand or to explain his absence. ${ }^{222}$

Treating the invoking statements of employees as vicarious statements of the corporation itself might seem unfair to the corporate defendant. After all, if corporate counsel had attempted to cross-examine the employees at their depositions, the employees might have invoked the privilege just as they did in response to the plaintiff's questions. Yet treating employees' statements about their fear of self-incrimination as vicarious statements means that they will come before the jury despite the absence of cross examination. Moreover, one reason for admitting vicarious statements is that the defendant-employer may usually call the employee to the stand to explain his earlier statements. But this will not be the case if as recommended here the invoking employees are barred from testifying. Hence it will be more difficult for the defendant corporation to develop evidence to explain the employees' earlier invokings. Especially since many invokings prove so little and prejudice so much, the defense might argue, admitting them unduly increases the corporation's civil exposure and allows invok-

219. 4 D. LOUISELL \& C. MUELLER, supra note 208, at 320.

220. Courts have admitted depositions of employees as vicarious admissions under FED. R. EvID. 801(d)(2)(D) on several occasions. See, c.g., Kaiser Aluminum \& Chem. Corp. v. Illinois Cent. Gulf R.R., 615 F.2d 470, 476 (8th Cir. 1980); Rule v. International Ass'n of Bridge, Structural \& Ornamental Ironworkers, Local Union No. 396, 568 F.2d 558, 569 n.17 (8th Cir. 1977). Of course, such depositions are usually admissible on other grounds. If the employee testifies, parts of his deposition may be admissible as prior inconsistent statements. FED. R. EVID. 801 (d)(1)(A). If the employee was subject to cross-examination at the deposition and is unavailable at trial, his deposition is admissible under FED. R. EvID. 804(b)(1).

221. See Mahlandt v. Wild Canid Survival \& Research Center, 588 F.2d 626 (8th Cir. 1978) (admitting against corporation opinion of corporate agent about cause of plaintiffs injuries even though agent lacked personal knowledge of underlying facts). C. MCCORMICK, supra note 48, at 63233 (conclusory opinions of agents are admissible).

222. See C. MCCORMICK, supra note 48 , at $629-30$. 
ing employees to manufacture "evidence" against the corporation at no legal risk to themselves.

A few practical considerations put this supposed inequity into perspective. First, corporate counsel will be able to hear the employee's story at one time or another. The corporate employee has a duty, unmitigated by any privilege, to reveal his information to the corporate agent appointed to reply to interrogatories and requests for admissions addressed to the corporation. ${ }^{223}$ Second, the corporate defendant will often be able to influence an employee's decision about whether to invoke. This influence may reduce the already low risk that employees will invoke solely to suggest the guilt of an innocent corporate employer. Third, a corporate defendant is commonly held responsible for the behavior of its employees during litigation. For example, the opposing party is normally allowed to urge the jury to draw an adverse inference against the corporate defendant whose employee has fled the jurisdiction before trial; that corporate counsel tried to prevent the flight is immaterial. ${ }^{24}$ Furthermore, courts have not hesitated to take measures against a corporate plaintiff whose employee invokes; these measures have included dismissal of the corporation's complaint. ${ }^{225}$

Corporate defendants might argue that admitting their employee's invokings against them will not improve discovery because the employees will invoke in any event, in order to reduce his own criminal exposure. But this argument misses the point. Unless an employee's invoking is admissible in the civil case against the employer-defendant, the defendant will possess a strong incentive to pressure its employee to invoke in order to stymie the plaintiff. Admitting the employee's invoking at least reduces that incentive and thus should tend to open up discovery. Even if discovery is not improved, admitting employee invokings will reduce the strategic advantage those invokings give the defense.

\section{See supra p. 1069.}

224. FED. R. CIV. P. 37(b)(2) illustrates the extent to which a corporate party is exposed to sanctions when its officers, directors, or managing agents fail to comply with discovery orders. The sanctions extend to rendering a default judgment against the corporation. Id. See also Diaz v. Southern Drilling Corp., 427 F.2d 1118 (5th Cir. 1970) (affirming default judgment against corporate defendant because corporate officer willfully failed to appear for deposition). Invokings of corporate employees during litigation in which the corporation is a party are just as attributable to the corporation.

Remedies should not be denied merely because the corporate party shows that its attorneys or executives exercised all reasonable efforts to discourage the invoking. But see Independent Prods. Corp. v. Loew's, Inc., 30 F.R.D. 377, 381-82 (S.D.N.Y. 1962) (reducing sanctions against corporation whose officer persisted in asserting privilege despite good faith efforts of corporation).

225. See, e.g., George Campbell Painting Corp. v. Reid, 392 U.S. 286 (1968); United States v. 42 Jars, More or Less, of "Bee Royale Capsules," 264 F.2d 666 (3d Cir. 1959). 


\section{iv. The Relevancy Problem}

Assuming that the invokings of the defendant and its employees are treated as statements of a party, defendants still might claim either that the invokings do not prove any relevant fact in issue in the civil case or that their probative value is outweighed by their prejudicial impact. ${ }^{226}$ The probative value of the invokings in establishing facts relevant to civil liability will vary from case to case and from question to question, and the parties undoubtedly will seek to establish why the privilege was invoked and what a complete response would have admitted. Occasionally, the invokings will be highly probative. But when a shrewd defendant and its employees invoke the privilege at the earliest opportunity, refusing, for example, to answer any questions about their work, the invokings merely suggest in a vague way that some circumstantial evidence of some criminal conduct exists. ${ }^{227}$ In such a case, no one but the invoker can do more than guess about the information being suppressed. The more innocuous and open-ended the question, the less the plaintiff and the factfinder can ascertain what the invoking shows. The suppressed response might have implicated the defendant in crimes other than those creating liability in the civil case. The response might have tended to incriminate only because it would have created the mistaken appearance of criminal conduct. Or the privilege might have been invoked purely as a safety measure by one who believed himself innocent but who still felt uncertain about the possible application of complex laws to his conduct. If attorneys routinely advise clients to invoke as a safety measure, courts might believe that the probative value of invokings is marginal.

But even when invokings in response to apparently innocuous questions do not reveal much about whether the invoker engaged in the conduct at issue, they at least show the factfinder why the plaintiff has not been able

226. See FED. R. EVID. 403 (relevant evidence may be excluded if its probative value is substantially outweighed by its prejudicial effect).

227. The most careful analysis of the inferences that logically follow from an invoking remains Noonan, supra note 43. In civil cases, Professor Noonan concluded, an invoking at least creates an inference that circumstantial evidence of the invoker's criminal conduct exists. Id. at 322-31. But Professor Noonan did not discuss whether invokings in civil cases also create an inference that circumstantial evidence exists of the invoker's actionable conduct. Whether and to what extent invokings suggest actionable conduct will vary with the circumstances. In general, when the civil case contains allegations of an essentially criminal nature the invoking is more likely to be probative. In a famous civil case based on fraud, invokings and refusals to testify by employees of corporate defendants were found highly probative:

These gentlemen [officers of the defendant corporation] have the right to remain silent, to evade, to refuse to furnish information, and thus to defy the government to prove its case; but a court of equity has the right to draw reasonable and proper inferences from all the circumstances in the case, and especially from the silence of Secretary Fall and from the failure of Sinclair to testify.

United States v. Mammoth Oil Co, 14 F.2d 705, 729 (8th Gir. 1926) (equitable action arising from Teapot Dome scandal), affd, 275 U.S. 13 (1927). 
to establish his case from the invoker's lips. The invokings at least explain why the plaintiff has resorted to other evidence, often less direct and inferior. The more vague and circumstantial the plaintiff's evidence, the stronger the inference against him from his apparent failure to confront those in possession of more direct evidence. Revealing the invokings dispels the inference that the plaintiff is calling less knowledgeable witnesses only because he knows or fears that the more knowledgeable invoker would provide adverse information. Hence, the negative relevance of invokings-their tendency to dispel the unspoken inference against the plaintiff-must be added to their positive relevance-their tendency to make the facts at issue more or less likely. 228

Admittedly, bringing an invoking to the jury's attention will prejudice the invoker. The revelation that he has claimed the privilege marks him as a criminal who has probably eluded justice. The jury is not likely to realize that the innocent may invoke. The invoking may also distract the jury from the main issues in the case by drawing their attention to the invoker's character and inviting speculation about the crimes he may have committed. Furthermore, admitting the invoking may increase delay by encouraging defense counsel to offer evidence about possible crimes, unrelated to the instant civil case, that may have prompted the invoking. ${ }^{229}$

In short, some out-of-court invokings may be excluded from evidence if a court balances only the apparent positive and negative probative value against the possible prejudice, distraction, and invitation to delay. To support a general rule admitting invokings of defendants and their employees, the procedural and equitable reasons favoring admission must also be allowed to enter into the calculus. Courts must consider the threat that invokings present to the policies underlying liberal discovery and to plaintiffs' right to meaningful access to the courts. They must also consider the inadequacy of the other possible remedies for plaintiffs.

The defendant who invokes so early as to obscure the probative value of

228. Professor Saltzburg has emphasized that in applying FED. R. EVID. 403, see supra note 226, courts should evaluate the negative as well as the positive relevance of evidence. That is, evidence may be relevant to counteract a negative inference from a party's failure to offer other evidence as wcll as to make a fact in issue more or less probable. Saltzburg, A Special Aspect of Relevance: Countering Negative Inferences Associated with the Absence of Evidence, 66 CALIF. L. REV. 1011, 1019 (1978). As the Supreme Court has pointed out, juries draw negative inferences from the absence of certain evidence. Carter v. Kentucky, 450 U.S. 288, 298-303 (1981).

Of course, defendants may claim that when they or their employees invoke and therefore fail to testify as defense witnesses, the jury is as likely to draw an inference against them as against the plaintiff. See, e.g., Interstate Circuit, Inc. v. United States, 306 U.S. 208, 226 (1939) (drawing inference against civil defendants from failure of their executives to testify). Admitting that such an inference is also likely, however, does not detract from the fact that when the plaintiff fails to call the most knowledgeable witnesses, an inference may arise against him which he should be able to counter by explaining that those witnesses have invoked.

229. Under FED. R. EviD. 403 evidence should be excluded if its probative value is substantially outweighed by the dangers of delay or confusion of issues. 
his invokings is in no position to complain when his own invokings are admitted. In any event his counsel will remain free to explain to the jury why the invokings prove nothing and to suggest why the privilege was invoked at all.

Other equitable considerations also call for admitting the invokings of the defendant's employees. ${ }^{230}$ If the defendant's own invokings are not revealed, the jury at least will realize that the defendant failed to testify and can draw inferences favorable to the plaintiff. But when the defendant's employees never appear, an inference favorable to the plaintiff is less likely, if only because the jury may be uncertain about the employee's role or even his existence. Moreover, unless employee invokings of marginal probative value are admitted, a defendant-employer facing civil exposure may possess a tremendous incentive to pressure his employees to invoke in such a way as to minimize the probative value of their invokings. In civil price-fixing cases, for example, all defendant-employers might be sorely tempted to badger employees into invoking at every opportunity. ${ }^{231}$

These considerations call for admitting past invokings generally and letting the attorneys argue their probative value to the factfinder. The factfinder should learn the questions prompting each invoking. If the invoker or his attorney announced an intention to invoke in response to all questions on certain subjects, with the result that further questioning on those subjects ceased, the factfinder should learn of that announcement. To avoid confusing the jury, counsel should explain the nature of the discovery instruments or proceedings during which the invoking occurred. The court's instructions should indicate that the jury is free to consider the invokings insofar as they tend to establish the facts in issue. ${ }^{232}$

Because the reasons for admitting the invokings are not purely evidentiary, courts might choose to ground their admission upon procedural and equitable considerations alone. Then courts could refuse to admit invokings with slight probative value if those invokings have not interfered materially with the plaintiff's discovery. For example, a defendant who invoked in a criminal trial but responded fully to discovery requests throughout a later civil suit should not have his invoking admitted against

230. To admit into evidence the invokings of the defendant himself but not the invokings of employees of corporate defendants would lead to incongruous results. When a sole proprietorship is sued, the invokings of its owner will be admitted. Had he incorporated, his invoking would not be admissible in a suit against the corporation. Yet historically courts have attempted to restrict the protection that the privilege affords a corporation. Hale v. Henkel, 201 U.S. 43, 52 (1906).

231. In certain circumstances, courts have recognized a public policy against one person advising another to invoke. See, e.g., Cole v. United States, 329 F.2d 437, 443 (9th Cir. 1964) (advising another to invoke constituted obstruction of justice if done with corrupt motive).

232. Many discretionary decisions will remain for the court, including whether to instruct the jury that the invoker was entitled to invoke, and whether to allow defense counsel to repeat a selfserving statement the invoker may have given when he invoked. 
him at the civil trial unless evidentiary considerations alone warrant admission. ${ }^{233}$

But if out of court invokings are not considered admissible evidence, the source of the court's authority for bringing them to the jury's attention is unclear. The court may need to resort to its supervisory authority over discovery, an authority enabling it to enter any order justice requires to protect a party from oppression. ${ }^{234}$

On balance, the evidentiary basis for putting the invokings before the jury seems preferable. The modest fiction that all invokings during civil discovery sufficiently relate to liability to be admitted makes more sense than an equitable or procedural rule warning an invoker that although no sanctions against him are possible, the jury will be told of his methods.

\section{Shifting the Burdens}

Admitting invokings into evidence will not neutralize the full value of the privilege to the defense. If the defendant and its employees invoke throughout the civil case, the defense may suppress enough evidence about the disputed conduct that a failure of proof results, even when the factfinder considers the positive and negative probative value of the invokings. The court must then grant the defendant's motion to dismiss at the close of the plaintiff's case based on plaintiff's failure to present sufficient evidence of the defendant's actionable conduct. ${ }^{235}$ In such cases, the plain-

233. In general, any invokings by the defendant or its employees that have not interfered with the plaintiff's civil discovery should be treated in the civil case based on their evidentiary status alone. If their probative value is outweighed by their prejudicial effect, they should be excluded. Such invokings might have occurred in earlier criminal trials, grand jury investigations, or civil actions.

The same should be true when the government is the plaintiff in a civil suit. Otherwise, government attorneys handling grand jury investigations that may lead to a later civil suit as well as a criminal prosecution will be tempted to call witnesses before the grand jury merely to get their invokings on record for use in the civil suit. Cf. infra pp. 1132-33 (discussing need to prevent plaintiffs from abusing remedies proposed).

234. See FED. R. CIV. P. 26(c). On the other hand, it is clear that no sanctions are authorized under FED. R. CiV. P. 37 for failure to grant discovery of privileged information since under FED. $R$. Giv. P. 26(b)(1) privileged information is expressly made not discoverable. Moreover, the Supreme Court has emphasized that Rule 37 is the exclusive authority for sanctions for a violation of the discovery rules, and that courts have no inherent powers to create other sanctions. Societe Internationale pour Participations Industrielles et Commerciales, S.A. v. Rogers, 357 U.S. 197, 207 (1958).

In private antitrust cases, invokings by defendants or their employees may support an award of prejudgment interest even if they do not support Rule 37 sanctions. The Antitrust Procedural Improvements Act of 1980 states that in deciding whether to award prejudgment interest the court shall consider, among other factors, "whether . . . either party's representative . . . engaged in conduct primarily for the purpose of delaying the litigation or increasing the cost thereof." 15 U.S.C.A. $\S 15$ (3) (West Supp. 1982). While the issue has not yet been raised, lawful invokings may be found to constitute conduct engaged in primarily to delay or to increase the cost of litigation.

235. A defense strategy of invoking in order to assure a failure of proof is especially appealing because, as discussed above, an alert defense may reduce the probative value of the invokings by claiming the privilege as soon as possible, even in response to open-ended and apparently innocuous questions. See supra pp. 1123-24 (discussing low probative value of early invokings). 
tiff needs yet another remedy: The court should shift to the invoking defendant the burden of producing evidence about its conduct. This remedy would enable the plaintiff to survive a motion to dismiss at the close of his case.

The remedy would shift to the defendant the burden of introducing evidence sufficient to enable the factfinder to determine that the defendant has not engaged in the actionable conduct alleged in the plaintiff's complaint. Failure to meet this burden would result in a directed verdict on the issue against the defendant. Meeting the burden would return the parties to their original position, with the plaintiff bearing the risk of nonpersuasion, that is the burden of proving that the defendant did engage in the actionable conduct. ${ }^{236}$ Meeting the burden would also leave the issue of the defendant's conduct for the factfinder, unless the evidence was so imbalanced as to mandate a directed verdict. Should the issue of the defendant's conduct ultimately go to the jury, the earlier shifting of the burden of production would not affect the jury instructions. ${ }^{237}$ Of course, the court may still instruct the jury to consider the probative value of the defendant's invokings.

To prevent abuse, courts should not employ the proposed remedy automatically whenever a defendant or its employees invoke. The invokers may have responded extensively to queries about their conduct and in-

236. In the federal system, FED. R. EvID. 301 forbids shifting to the defendant the ultimate burden of proof concerning his conduct. The rule adopts the so-called "bursting bubble" approach, under which only the burden of production may be shifted. See FED. R. EvID. 301 advisory committee note (discussing "bursting bubble" approach).

Whether the bursting bubble approach should be rejected in favor of shifting the burden of proof as well as the burden of production lies beyond the scope of this Article. For arguments in support of the bursting bubble approach, see J. THAYER, PRELIMINARY TREATISE ON EVIDENCE AT THE COMMON LAW 336-37 (1898); 9 J. WIGMORE, EVIDENCE § 249(2) (3d ed. 1940). Some commentators have objected to this approach because it does not give adequate weight to the reasons for the presumption. E.g., Cleary, Presuming and Pleading: An Essay on Juristic Immaturity, 12 STAN. L. REv. 5 (1959); Morgan \& Maguire, Looking Backward and Forward at Evidence, 50 HARV. L. REv. 909, 913 (1937). The proposed Federal Rules of Evidence rejected the bursting bubble approach, but Congress restored it. See FED. R. EVID. 301 House and Senate Judiciary Committee notes.

Under the compromise reflected in the 1953 version of the Uniform Rules of Evidence, the bursting bubble approach was followed only if the immediate basis for the presumption did not tend to prove the facts presumed; when the presumption arose because of the probative value of the plaintiff's evidence, the burden of proof was shifted as well. UNIFORM RULES OF EVIDENCE Rule 14 (1953). The primary reason for shifting the burden when the privilege against self-incrimination is invoked is the defendant's superior knowledge and access to evidence about its conduct rather than the probative value of the invokings in showing that conduct. Thus, the compromise view would apply the bursting bubble approach to an invoking. Moreover, the bursting bubble approach adequately serves the goal of "smoking out" the defendant's version of events, a key goal whenever burdens shift because the defendant has superior access to the evidence. The bursting bubble approach would also avoid any constitutional objections that might be based on Western \& Atl. R.R. v. Henderson, 279 U.S. 639 (1929) (presumption that shifts both burden of producing evidence and burden of proof is unconstitutional unless rational connection exists between facts proven and facts presumed).

237. See Louisell, Construing Rule 301: Instructing the Jury on Presumptions in Civil Actions and Proceedings, 63 VA. L. REV. 281, 301 (1977). 
voked only when asked about matters peripheral to the civil case. Sometimes the circumstances may indicate that the failure of proof results from the plaintiff's lack of diligence or the obvious lack of merit in his allegations. Equity does not require shifting the burden in such instances. Rather, the burden should shift only when the invokings appear to have contributed substantially to the plaintiff's failure of proof. By the time the plaintiff has completed the presentation of his case, the court should be sufficiently familiar with the allegations and the discovery background to be able to apply this standard.

There is nothing unusual or extreme about this proposed remedy. The legal system no longer automatically imposes the burdens of proof and production on the party with the burden of pleading the issue. ${ }^{238}$ Instead, fairness and experience guide the allocation of these burdens. Equitable factors to be considered include the parties' relative knowledge of the facts and their access to evidence. ${ }^{239}$ Accordingly, courts sometimes shift the burdens to the defense on the ground that it possesses superior knowledge of the facts. In torts cases, for example, defendants faced with a claim of res ipsa loquitur may need to make a preliminary showing that they were not negligent. ${ }^{240}$ Similarly, a bailee of damaged goods bears the burden of proving either that he was not negligent or that his negligence did not

238. $9 \mathrm{~J}$. WIGMORE, supra note $236, \S 2486$.

239. See Morgan, Some Observations Concerning Presumptions, 44 HaRV. L. REV. 906, 910-11 (1931). A party's relative knowledge and access to evidence is not the only factor to be considered in allocating the burden. In Wigmore's words, "the consideration furnishes no universal working rule"; rather, it "merely takes its place among other considerations of fairness and experience as a most important one to be kept in mind in apportioning the burden of proof in a specific case." $9 \mathrm{~J}$. WIG. MORE, supra note $236, \S 2486$, at 275 . The Supreme Court has recognized the importance of the party's knowledge and access to evidence in allocating the burdens. See United States v. New York, N.H. \& H.R.R., 355 U.S. 253, 256 n.5 (1957); Commercial Molasses Corp. v. New York Tank Barge Corp., 314 U.S. 104, 111 (1941).

240. The famous tort case of Ybarra v. Spangard, 25 Cal. 2d 486, 154 P.2d 687 (1944), illustrates this rule. After an appendectomy, the plaintiff in Ybarra awoke with a paralyzed right shoulder. He attempted to invoke the doctrine of res ipsa loquitur, but was unable to indicate which of those treating him was probably guilty of the negligence that caused his injury. In reversing a nonsuit, the California Supreme Court, referring to res ipsa loquitur, announced:

If the doctrine is to continue to serve a useful purpose, we should not forget that the particular

force and justice of the rule, regarded as a presumption throwing upon the party charged the

duty of producing evidence, consists in the circumstance that the chief evidence of the true cause, whether culpable or innocent, is practically accessible to [the defendants] but inaccessible to the injured person.

Id. at 490,154 P.2d at 689 . The court's ruling thus required the defendants to make a preliminary showing of their own lack of negligence. Just as judicial opposition to a suspected conspiracy of silence among the defendant doctors and nurses may have provided the impulse for Ybarra, opposition to the defense team's strategy of blocking discovery by having defendants and their employees invoke at every opportunity may provide the impulse for shifting the burdens here.

The need to shift the burden of production in order to "smoke out" the party with superior access to the evidence diminishes as the opposing party becomes more able to obtain the evidence through discovery. More liberal rules of discovery, therefore, have rendered the Ybarra approach unnecessary except when some reason-such as a privilege-prevents the plaintiff from obtaining the evidence through discovery. 
cause the damage. ${ }^{241}$

An invoking defendant plainly knows more about his own conduct, and is likely to enjoy better access to significant evidence, than a plaintiff who is kept outside the "conjurer's circle" created by the privilege. Moreover, a corporate defendant is more likely than a plaintiff to learn about the conduct of its invoking employees, if only because the employees must assist their employer in responding to interrogatories addressed to the corporation. In the rare case in which an employer cannot learn about its employees' conduct directly from the invoking employees, it still has greater access to other sources of information such as other employees or company records. Its superior access to these other sources better equips it to present evidence of the invoking employees' conduct despite any obstructions imposed by the invokings.

Other equitable considerations also support shifting the burden of producing evidence about the defendant's conduct. As discussed above, an invoking by a defendant or his employee ought to be treated for evidentiary purposes as an admission by a party that the reply would suggest criminal conduct. ${ }^{242}$ To call on such a party to explain why the evidence suggests its criminal liability but fails to show civil liability to the plaintiff hardly seems unjust, especially since the voluntary invokings of the defendant or his employees foreseeably contributed to the plaintiff's lack of evidence. ${ }^{243}$

Some courts seem increasingly aware that equity may require the shifting of burdens when a privilege not designed to further policies related to

241. E.g., Knowles v. Gilchrist Co., 362 Mass. 642, 651, 289 N.E.2d 879, 884 (1972) (placing burden of proof on bailee, who has greater access to evidence of due care or negligence).The burden shifts to the bailee-defendant solely because he or his employees usually possess superior knowledge of the cause of the damage and superior access to the critical evidence. There is no suggestion that the burden shifts because of the probative value of the evidence in showing probable liability. The burden of production and the burden of proof may also be shifted in other contexts if the defendants enjoy superior knowledge or access to evidence. Sec, e.g., Browzin v. Gatholic Univ., 527 F.2d 843, 849 (D.C. Cir. 1975) (dictum) (defendant university's superior access to information may justify shifting to it burden of proving reasonable efforts to find alternative position for dismissed professor); Lake v. Callis, $202 \mathrm{Md}$. 581, 97 A.2d 316 (1953) (shifting to bankrupt burden of showing what happened to proceeds of mortgage loan).

242. See supra pp. 1117-28.

243. After invoking, the balance of equity between the parties resembles that in tort cases where there is evidence of the defendant's negligence but, due to unavoidable circumstances, it is unclear whether the negligence probably caused the plaintiff's injury. A well known example is Summers v. Tice, 33 Cal. 2d 80, 199 P.2d 1 (1948), in which it was clear that the plaintiff was injured by one of two defendant hunters who shot in his direction but unclear as to which defendant's shot probably hit the plaintiff. The court shifted both the burden of production and the burden of proof on the causation issue to the defendants on the equitable ground that the mystery about causation, if not dispelled, should be resolved in favor of the injured plaintiff rather than the apparently negligent defendants. Summers suggests that the defendants' culpability, supported by the invoking statement, is another factor to be considered in allocating burdens.

This is not to suggest that the defendant's invoking-an act that foresecably can lead to the plaintiffs failure of proof-constitutes wrongdoing of any kind. Consequently, cases such as Haft v. Lone Palm Hotel, 3 Cal. 3d 756, 478 P.2d 465, 91 Cal. Rptr. 745 (1970), which call for shifting the burden when the defendant's wrongful acts foreseeably cause the failure of proof, do not apply. 
civil liability obstructs access to matters essential to a plaintiff's case. Recent defamation cases against newspapers illustrate this approach. Under modern defamation law, a plaintiff must show that the defendant newspaper was at least negligent in publishing false and defamatory facts: ${ }^{244} \mathrm{~A}$ newspaper may be negligent if it reports information from plainly unreliable sources. ${ }^{245}$ While a reporter can be forced to reveal his sources, ${ }^{246}$ the New Hampshire Supreme Court has chosen to shift burdens in an attempt to ensure fair treatment for the plaintiff while avoiding unnecessary contempt proceedings against reporters who refuse to reveal sources. ${ }^{247}$ The Court's approach is to presume from the reporter's failure to disclose the source that no source in fact existed. This presumption allows the plaintiff to survive a motion to dismiss for failure to show negligence but still requires him to show the other elements of his action-that the publication was false and defamatory. The reporters, on the other hand, will not need to reveal sources unnecessarily; they will only need to do so when the plaintiff has presented sufficient evidence on the other elements of his case.

The need to shift the burden of producing evidence when defendants or their employees invoke will arise only when the plaintiff fails to present sufficient evidence of the defendant's actionable conduct. But without this remedy, the defense will be tempted to use the privilege to draw the widest possible "conjurer's circle" about its conduct while gambling on the plaintiff's inability to find sufficient evidence elsewhere.

\section{Barring the Midnight Witness}

The privilege becomes an offensive weapon when the defendants or their employees who have previously invoked waive their privilege in order to testify at trial. The remedy recommended here is to prevent the previous invokers from testifying, at least until they submit to a deposition at which they waive the privilege and respond to the plaintiff's questions. $^{248}$

244. See, e.g., Gertz v. Robert Welch, Inc., 418 U.S. 323 (1974) (private citizen must show some fault on part of defendant newspaper); New York Times Co. v. Sullivan, 376 U.S. 254 (1964) (public official must show "actual malice" on part of defendant newspaper).

245. E.g., St. Amant v. Thompson, 390 U.S. 727, 732 (1968).

246. Herbert v. Lando, 441 U.S. 153 (1979).

247. Downing v. Monitor Publishing Co., 120 N.H. 383, 415 A.2d 683 (1980). The approach in Downing was followed in DeRoburt v. Gannett Co., 507 F. Supp. 880 (D. Hawaii 1981), and cited with approval in Bruno \& Stillman, Inc. v. Globe Newspaper Co., 633 F.2d 583, 597 (1st Cir. 1980).

248. A few courts have barred the previous invoker from testifying. E.g., Duffy v. Currier, 291 F. Supp. 810, 815 (D. Minn. 1968); A \& M Records v. Heilman, 75 Cal. App. 3d 554, 566, 142 Cal. Rptr. 390, 397 (Cal. Ct. App. 1977); Constanza v. Constanza, 66 N.J. 63, 328 A.2d 230 (1974). Because the invokers have not violated any discovery rules, the authority for barring the testimony arises under FED. R. CIV. P. 26(c) (or its state equivalents), which authorizes any orders needed to protect a party from oppression. Other courts have merely postponed the invoker's testimony unless he 
To allow the previous invokers to proceed with their testimony at trial mocks the discovery process. The defendant may claim that the plaintiffs are adequately protected as long as they are able to bring out the prior invokings for impeachment purposes, should they appear inconsistent with the in-court testimony. But this claim ignores the tremendous strategic advantages the defense obtains from concealing its version of events until the middle of the trial. Allowing the invokers to testify forecloses the plaintiff's opportunity to scrutinize, investigate, and prepare to neutralize the defense version of events, an endeavor for which ample time would have been available save for the earlier invokings. The policy considerations that require giving these advantages to a criminal defendant do not operate in a private civil case..$^{249}$

The prejudice to the plaintiff resulting from this defense stratagem rarely will be cured merely by postponing the invoker's testimony until the plaintiff can depose him. This approach is appropriate only if sufficient time remains between the last-minute deposition and the in-court testimony to permit the plaintiff to prepare his case adequately. Even then, the delay caused by the previous invokings invariably works to the defense's advantage. By postponing their responses, defendants and their employees gain the valuable opportunity to adjust them in light of the plaintiff's evidence. Prejudice also may arise from the plaintiff's loss of preparation time. If the trial has begun before past invokers announce their desire to waive, the entire trial usually will need to be postponed, for the plaintiff certainly would be prejudiced if required to depose the invokers, follow up the depositions, and adjust his case accordingly while fully embroiled in the trial. Postponing the trial, not coincidentally, usually favors the defense. Accordingly, in the vast majority of instances in which an invoker does not waive the privilege until trial, the court should bar him entirely from testifying. ${ }^{250}$

When previously invoking defendants and their employees indicate before trial their willingness to waive and respond to discovery, the decision whether to allow them to testify at trial should turn on the degree of prejudice caused the plaintiff by their earlier invokings. The court should consider the length of time between the invokings and the invokers' change of heart, and between their change of heart and trial; the extent to

submits to a deposition where the privilege is waived. E.g., Meyer v. Second Judicial Dist. Court, 591 P.2d 259 (Nev. Sup. Ct. 1979).

249. See, e.g., United States v. Wright, 489 F.2d 1181, 1192-95 (D.C. Cir. 1973) (discussing why criminal defendant need not submit to broad discovery expected from civil defendant).

250. An order barring the invoker from testifying should not raise constitutional problems. $C$. Williams v. Florida, 399 U.S. 78 (1970) (state statute requiring defendant to disclose names of alibi witnesses prior to criminal trial or be barred from testifying does not violate Fifth Amendment privilege). 
which the invokings enabled them to learn about the plaintiff's evidence before responding; and the extra costs incurred by the plaintiff. Of course, even if the invokers are allowed to testify at the trial, their previous invokings in the civil case should be admissible.

When the defendants or their employees have responded to some lines of questioning and invoked on others during discovery, they should be barred from testifying on the subjects and questions to which they invoked. The difficult issue becomes whether they should be allowed to testify on the subjects and questions to which they responded. The standards currently applied in criminal cases when an in-court witness testifies in part and invokes in part should govern here. ${ }^{251}$ They require the court to determine first whether the privilege was properly invoked; often by responding on some lines of questioning, the invokers will have waived the privilege. 252 Assuming the privilege was properly invoked, the court should strike the entire testimony unless the questions to which the witness invoked concerned collateral rather than direct matters. ${ }^{253}$ Questions relating solely to the credibility of the witness usually are deemed collateral; questions relating to the subject-matter of his testimony invariably are deemed direct. ${ }^{254}$ The line between direct and collateral matters is not clear, and many invokings undoubtedly will be difficult to categorize. The fundamental issue, however, is whether the plaintiff's inability to obtain a response to some of his questions creates a substantial danger of prejudice by depriving him of the opportunity to test the truth of the witness's other testimony. ${ }^{255}$ Of course, even if the court allows some testimony from a former invoker, the plaintiff should be able to admit into evidence the full circumstances of the witness's earlier invokings.

\section{Controlling the Remedies when Prosecution Is Pending}

A special situation arises when the defendant or employee from whom information is requested in the private civil case is also a defendant in a pending criminal prosecution. In such a case, there is an acute risk that

251. See Dunbar v. Harris, 612 F.2d 690 (2d Cir. 1979) (refusal of prosecution witness on Fifth Amendment privilege grounds to answer questions on cross-examination did not require striking of his direct testimony, because questions on cross-examination related to collateral matters); United States v. LaRiche, 549 F.2d 1088, 1096-97 (6th Cir. 1977) (same), cert. denied, 430 U.S. 987 (1979).

When a witness testifies voluntarily, the privilege is waived on cross-examination as to matters made relevant by the testimony on direct. See Brown v. United States, 356 U.S. 148 (1958). One court recommends striking the civil defendant's entire trial testimony when he invokes at any point. Annest v. Annest, 49 Wash. 2d 62, 63, 298 P.2d 483, 484 (1956).

252. Rogers v. United States, 340 U.S. 367, 374 (1951).

253. United States v. Stephens, 492 F.2d 1367, 1375 (6th Cir.), cert. denied, 419 U.S. 852 (1974); United States v. Cardillo, 316 F.2d 606 (2d Cir.), cert. denied, 375 U.S. 822 (1963).

254. Coil v. United States, 343 F.2d 573 (8th Cir.), cert. denied, 382 U.S. 821 (1965).

255. United States v. Decidue, 603 F.2d 535, 552 (5th Cir. 1979), cert. denied, 445 U.S. 946 (1980). 
responses to discovery requests in the civil case will harm the defendant's strategic position in the criminal case. Faced with such a dilemma, most criminal defendants, innocent or guilty, probably would choose to invoke in the civil case.

In this situation, the automatic triggering of the various remedies proposed above in the civil case would invite some abuse. ${ }^{256}$ Plaintiffs and potential plaintiffs would be tempted to schedule civil discovery before the criminal trial merely to get the criminal defendant's invoking on the record. Plaintiffs then would be assured of being able to admit the invoking against the invoker or his employer and, perhaps, of barring the invoker from testifying. Thus, the proposed remedies, however appropriate for neutralizing the privilege weapon generally, would operate harshly in light of the practical pressure on the criminal defendant to invoke.

A court alert to these concerns can obviate any need for the criminal defendant to invoke by staying the plaintiff's discovery requests directed to the criminal defendant until after the conclusion of the criminal trial. ${ }^{257}$ Granted, the plaintiff will be disadvantaged by the postponement of what might be his most important discovery requests. But the Speedy Trial

256. The situation here where plaintiff is seeking discovery must be distinguished from that arising when a party to the prosecution in a pending criminal trial demands discovery as a litigant in the civil suit. Then the danger that the party is demanding discovery to circumvent the limits on criminal discovery increases the need for a stay. In such cases the courts often stay all civil discovery. See, e.g., United States v. Mellon Bank, 545 F.2d 869 (3d Cir. 1976); United States v. Bridges, 86 F. Supp. 931 (N.D. Cal. 1949).

257. Such stays have been granted. See, c.g., Perry v. McGuire, 36 F.R.D. 272 (S.D.N.Y. 1964); Paul Harrigan \& Sons, Inc. v. Enterprise Animal Oil Co., 14 F.R.D. 333 (E.D. Pa. 1953); National Discount Corp. v. Holzbaugh, 13 F.R.D. 236 (E.D. Mich. 1952). The usual standards for staying part of a civil suit pending completion of a criminal case require the party requesting the stay to show that going forward would inflict a greater hardship on him than the stay would inflict on the opposing parties and on the public interest. See Landis v. North Am. Co., 299 U.S. 248, 254-56 (1936). In addition, the stay must not be broader in scope or extend for a longer period than is reasonably necessary. See Dellinger v. Mitchell, 442 F.2d 782, 786-87 (D.C. Cir. 1971); Texaco, Inc. v. Borda, 383 F.2d 607, 608-09 (3d Cir. 1967).

Many courts in civil cases have refused to grant a stay of discovery from a party who is also a criminal defendant pending the disposition of the related criminal case. These courts have held that the public interest in the speedy progress of the civil proceedings outweighed the criminal defendant's interest in withholding his testimony until after the criminal proceedings are complete. See, e.g., De Vita v. Sills, 422 F.2d 1172 (3d Cir. 1970); Coalition of Black Leadership v. Cianci, 480 F. Supp. 1340 (D.R.I. 1979); SEC v. Gilbert, 79 F.R.D. 683 (S.D.N.Y. 1978).

When the court in charge of the civil case refuses to stay discovery from the criminal defendant, the court in the criminal case should not be tempted to enjoin the civil proceedings. The criminal defendant may protect his rights in the criminal case by invoking in the civil case, provided the adverse publicity from that invoking can be controlled. Therefore, the civil proceedings do not threaten the criminal defendant's rights, although they may indeed unearth incriminating evidence that the prosecutors may use. Comity considerations also weigh against interference in the civil case. See United States v. American Radiator \& Standard Sanitary Corp., 388 F.2d 201, 204 (3d Cir. 1967); United States v. Simon, 373 F.2d 649, 652-53 (2d Cir. 1967). See generally Landis v. North Am. Co., 299 U.S. 248, 254-55 (1936) (discussing considerations pertinent to decision to stay civil proceeding). When the criminal defendant responds to discovery in the civil case after a stay is denied, his responses are not considered "coerced" and are admissible against him in the criminal case. See United States v. Solomon, 509 P.2d 863 (2d Cir. 1975). 
Act, ${ }^{258}$ together with its state equivalents, should minimize the postponement of the plaintiff's discovery. The harm to the plaintiff will also be mitigated if he is allowed to proceed with his other discovery requests. ${ }^{250}$

This proposal is not meant to suggest that the defendant will be unable to invoke once his criminal trial is over. He may continue to invoke as long as his response might tend to incriminate him of any crime for which prosecution is theoretically possible. ${ }^{260}$ Rather, the assumption here is that the practical pressure on the criminal defendant to invoke regardless of guilt or innocence will have diminished upon the conclusion of the criminal trial. Moreover, the former criminal defendant who continues to invoke indefinitely imposes a much greater disadvantage on the plaintiff than one who invokes only before his criminal trial. Accordingly, any invoking by a civil defendant or his employees after the criminal trial should trigger the remedies recommended here, as long as no other indictments against the invoker remain.

To some extent, the same concerns that apply to those facing trial apply to invokers facing criminal investigation. The pressures on a target in a pending grand-jury investigation to avoid issuing statements in the civil case may also be severe. In fact, similar pressures apply to all invokers who face a genuine danger of future prosecution. But to allow the imposition of the recommended remedies to turn on whether the invoker faced a "sufficient" danger of prosecution would be to force yet another unworkable guideline on the courts. Although any bright-line rule seems arbitrary, a rule only allowing one who plans to invoke in a civil case to stay discovery from himself when he is the defendant in a pending criminal case provides a workable standard that reduces the potential hardships of both the defendant and the plaintiff. ${ }^{261}$

258. Speedy Trial Act of 1974,18 U.S.C. $\$ \S 3152-3156,3161-3174,28$ U.S.C. $\$ 604$ (1976). The $\Lambda \mathrm{ct}$ allows ten days from indictment to arraignment and sixty days from arraignment to trial. 18 U.S.C. $\S 3161(\mathrm{c})$. Delay of indictment or trial is permissible for various reasons specified in the Act. Id. $\$ 3161(\mathrm{~h})$.

259. Staying all discovery in the private civil case until the end of the criminal case is rarely appropriate unless all parties in the civil suit so desire. . See In re Mid-Atlantic Toyota Antitrust Litig., No. 456 (D. Md. May 26, 1981). The standards for staying all discovery are set forth in Golden Quality Ice Cream Co. v. Deerfield Specialty Papers, 87 F.R.D. 53, 56-58 (E.D. Pa. 1980).

260. See supra TAN 11.

261. Another concern when the invoker in the civil case is facing a criminal trial is the danger that admitting his past invokings into evidence at the civil trial will create pre-trial publicity that prejudices his right to a fair trial in the criminal case. This danger should not be overstated, however. For one thing, it should only arise when the civil trial is to occur shortly before the criminal trial.

Admittedly, when the invoking in the civil case occurs during civil discovery, but the civil trial itself is to occur after the criminal trial, publicity about the invokings may threaten the criminal defendant's rights, regardless of whether the invokings are admissible. But in this situation the courts should be able to reduce the publicity about the invokings by granting a protective order that would bar the civil parties from disclosing the invokings to the media. The parties should remain free, however, to disclose the invokings to the government. Because the government's own prosecutorial interests would be jeopardized by pre-trial publicity, it should refrain from disclosing the invokings to the media. 


\section{Conclusion}

Various administrative considerations defeat any attempt to confine the use of the privilege against self-incrimination in civil cases to occasions when the response would increase significantly the likelihood of criminal prosecution. Even so confined, the privilege, when fully exploited, puts the private civil plaintiff at a disadvantage more severe than previously appreciated. Especially when civil liability allegedly arises from criminal conduct, the privilege precludes discovery and frustrates the truth-determining capacity of the litigation process to an alarming extent. Admittedly, the measures recommended here do not directly improve the likelihood that the truth ultimately will be discovered. In themselves they primarily reduce the disadvantage plaintiffs suffer when the privilege weapon is used against them. By so doing, however, these measures, if employed consistently, should open up discovery by dissuading those who do not fear prosecution from using the privilege to draw a "conjurer's circle" around all aspects of their conduct.

\footnotetext{
At civil trials before the criminal trial, on the other hand, past invokings will inevitably come to the attention of the media. Rather than attempting to keep the invokings secret, the court in the civil case should explore other methods for reducing adverse publicity about them. For instance, the court in the civil case should consider cautioning the news media that publicizing the invokings will jeopardize the invoker's right to a fair trial in the ensuing criminal case. See ABA PROJECT ON STANDARDS FOR CRIMINAL JUSTICE, FAIR TRIAL AND FREE PRESS § 3.5(d) (1968).

The judge in the criminal case may also employ various methods to reduce the effect of publicity about earlier invokings. These include special questions and procedures on voir dire; sequestration of jurors; cautionary instructions to jurors, parties, and the media; exclusion of the public from certain hearings; and change of venue. Id. $\$ 3.1-.5$.

If the court in the civil case feels its efforts, even when combined with the efforts of the court in the criminal case, will not control the prejudice from publicity about the invoking, it should stay the civil trial until the criminal trial is finished. See United States v. American Radiator \& Standard Sanitary Corp., 388 F.2d 201, 205 (3d Cir. 1967).
} 